\title{
The Role of Epigenetics in Placental Development and the Etiology of Preeclampsia
}

\author{
Clara Apicella ${ }^{\dagger}$, Camino S. M. Ruano ${ }^{\dagger}$, Céline Méhats ${ }^{\circledR}$, Francisco Miralles and \\ Daniel Vaiman *iD
}

Institut Cochin, U1016 INSERM, UMR8104 CNRS, Université Paris Descartes, 24 rue du faubourg St Jacques, 75014 Paris, France; clara.apicella@inserm.fr (C.A.); camino.ruano@inserm.fr (C.S.M.R.); celine.mehats@inserm.fr (C.M.); francisco.miralles@inserm.fr (F.M.)

* Correspondence: daniel.vaiman@inserm.fr; Tel.: +33-1-4441-2301; Fax: +33-1-4441-2302

+ These authors contributed equally to this work.

Received: 3 May 2019; Accepted: 3 June 2019; Published: 11 June 2019

\begin{abstract}
In this review, we comprehensively present the function of epigenetic regulations in normal placental development as well as in a prominent disease of placental origin, preeclampsia (PE). We describe current progress concerning the impact of DNA methylation, non-coding RNA (with a special emphasis on long non-coding RNA (lncRNA) and microRNA (miRNA)) and more marginally histone post-translational modifications, in the processes leading to normal and abnormal placental function. We also explore the potential use of epigenetic marks circulating in the maternal blood flow as putative biomarkers able to prognosticate the onset of PE, as well as classifying it according to its severity. The correlation between epigenetic marks and impacts on gene expression is systematically evaluated for the different epigenetic marks analyzed.
\end{abstract}

Keywords: preeclampsia; epigenetics; DNA methylation; non coding RNAs; miRNAs; histone post translational modifications; HOX genes; H19; miR-210

\section{Introduction}

PE affects $\sim 2-5 \%$ of the pregnancies. This disease, characterized in the classical definition by hypertension and proteinuria, surging from the mid-gestation at the earliest, is often seen as a two-stage disease, where a placental dysfunction occurs, first without observable symptoms and is followed later by a symptomatic phase from the 20th week of gestation at the earliest. The placenta is central to the disease development [1]. During pregnancy, the cytotrophoblasts (CTs) invade and remodel the structure of the spiral arteries of the myometrium [2]. These changes cause a significant increase in blood flow to the placenta. In a classical vision of the disease etiology, it is said that deep invasion is deficient in preeclampsia [3]. It is generally acknowledged that in preeclamptic pregnancies, placentation is disrupted because the CTs fail to properly invade the myometrium and transform the spiral arteries [4]. This decreases the blood flow and alters the oxygenation of the placenta (causing hypoxia and hyperoxia events), triggering oxidative stress, necrosis and inflammation [5]. In a very stimulating paper, B. Huppertz challenges this classical understanding of PE etiology, by dissociating the defect of deep trophoblast invasion from preeclampsia but rather associating this defect with the Fetal Growth Restriction (FGR) phenotype [6]. In this vision, preeclampsia would rather be caused by a combination of villous trophoblast defects (which are not involved in invasion, contrary to extravillous trophoblast) and maternal susceptibility. He based his reasoning on the fact that invasion defects are actually not histologically visible in many cases of preeclampsia. This may be connected to mouse models of preeclampsia where no obvious fetal growth restriction occurs, consistently with the fact 
that invasion is not important in rodent [7]. More accepted than this vision, the same paper strengthens the idea that hyperoxia rather than hypoxia is a major actor of the disease $[6,8]$.

The preeclamptic placenta releases vasoactive molecules, pro-inflammatory cytokines, microparticles and syncytial fragments into the maternal circulation which ultimately cause a systemic endothelial dysfunction [9]. Epigenetics plays an important role in the regulation of the development and physiology of the placenta [10]. Besides, substantial epigenetic alterations, in the preeclamptic placenta and other affected tissues have been described and are likely playing a substantial role in the evolution of the disease [11-14].

\section{Epigenetics and Normal Placental Development}

\subsection{Description of the Placenta and Placental Cells}

The placenta is a temporary organ connecting the developing fetus to the uterine wall through the umbilical cord, to allow for nutrient absorption, thermal regulation, waste disposal and gas exchange via the mother's blood supply. In addition, the placenta produces hormones that support pregnancy and it acts as a barrier to fight against internal infection [15].

The human placenta at term has a discoid shape, an average diameter of 15-20 cm, a thickness of $2.5 \mathrm{~cm}$ in the center and a weight of about $500 \mathrm{~g}$. Its surfaces are the chorionic plate on the fetus side and to which the umbilical cord is attached and the basal plate facing the maternal endometrium. Between the endometrium and the basal plate there is a cavity filled with maternal blood, the intervillous space, into which branched chorionic villi project. The chorionic villi are the structural and functional unit of the placenta. Their core is made of fibroblasts, mesenchymal cells, endothelial cells, immune cells such as Hofbauer cells (supposed to be macrophage-like) and fetal-placental vessels. The villi are covered by two layers of trophoblasts. The inner layer is composed of villous cytotrophoblasts (vCTs), which are highly proliferative and can differentiate into either outer layer villous syncytiotrophoblasts (SCT), which are in direct contact with the maternal blood or extravillous trophoblasts (EVTs), as shown in Figure 1.

\subsection{Human Placental Development}

The development of the human placenta has been described in detail elsewhere [16-18]. Briefly, the blastocyst implants into the uterine endometrium (decidua) via the trophectoderm cells adjacent to the inner cell mass (ICM). From the trophectoderm, the syncytium (SCT) emerges and spreads. Subsequently, CTs proliferate rapidly to form large finger-like projections (villi) that penetrate the entire depth of the SCT. Ultimately, the villi become filled with mesenchyme originated from the extraembryonic mesoderm. This mesenchyme will form fetal blood vessels which connect to the fetal circulation via the umbilical cord. The intervillous space subsequently becomes filled with maternal blood. The vCTs situated at the tips of the anchoring villi proliferate and stratify, forming highly compact cell columns breached only by channels carrying maternal blood toward and away from the placenta (Figure 1). The trophoblast cells within this structure are referred to as EVTs, according to their external location relative to the chorionic villi. EVTs situated close to the decidua, stop proliferating and develop invasive properties. These invasive EVTs migrate deeply into the decidua, where they transform the uterine vasculature in order to supply the placenta maternal blood, a critical step in establishing uteroplacental circulation. As pregnancy progresses, the number of vCTs decreases and few is observable at term underneath the SCT. 
A
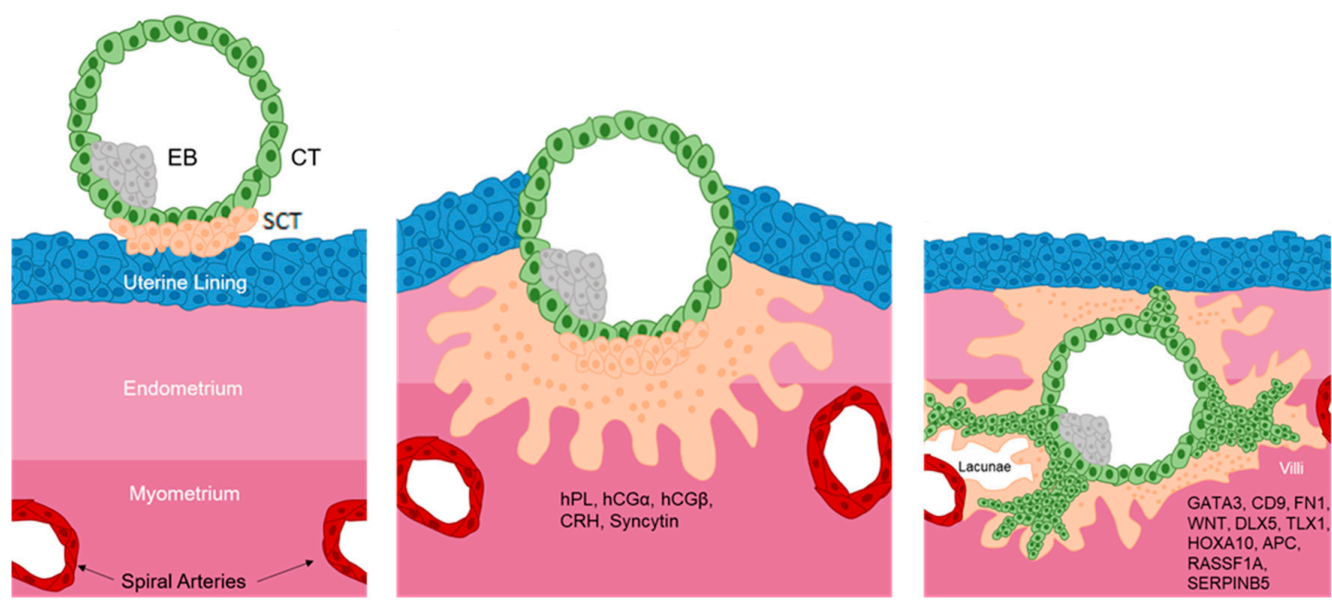

B

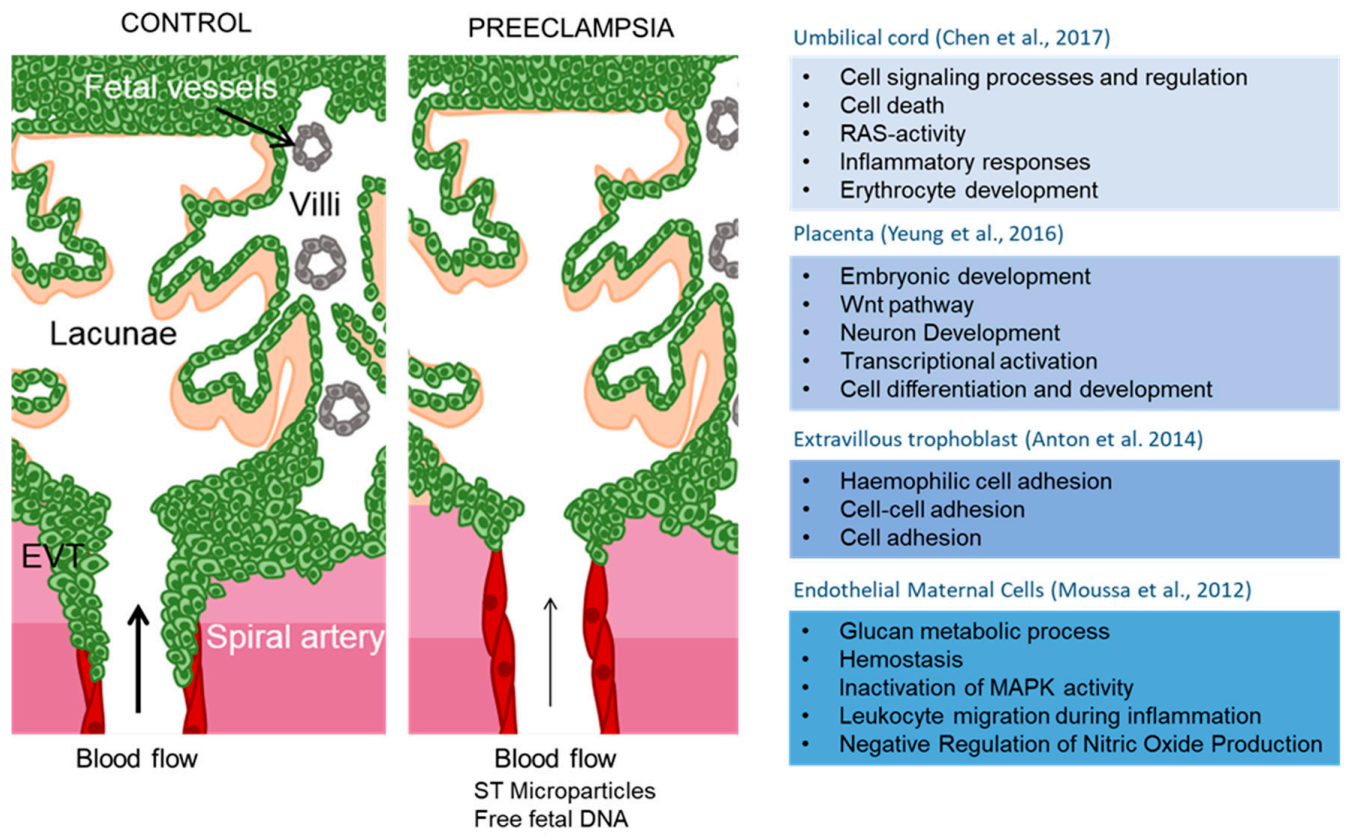

Figure 1. (A) Blastocyst implantation and Placenta Development: After recognizing the uterine lining, the blastocyst is formed by the embryoblast (EB) and the cytotrophoblast (CT). The cytotrophoblast starts to differentiate into Synctiotrophoblast (SCT). SCT invades the endometrium towards the maternal spiral arteries located in the myometrium. deregulation of numerous genes is observed [19]. Lacunae develop in the syncytiotrophoblast, which will eventually constitute the intervillous space. Genes upregulated during villi formation are presented on the right figure [20]. Other cytotrophoblasts will invade the maternal spiral arteries by differentiating into Extravillous trophoblast. (B) Gene Ontology of genes differentially methylated in PE compared to control samples: (Left) in normal pregnancies, extravillous trophoblast (EVT) invades the maternal spiral arteries allowing for an increased blood stream towards the extravillous space. Nutrients cross the placenta, are directed towards the embryonic vessels and collected in the umbilical cord. In PE, decreased invasion of the EVTs induces poor spiral artery remodeling, leading to poor blood flow towards the placenta. Increased amount of microparticles from the syncytiotrophoblast and increased amount of free fetal DNA is observed in the maternal blood. (Right) Gene ontology of differentially methylated genes found in PE samples in different tissues affected during pregnancy: Umbilical cord, placenta, EVT, Endothelial Maternal cells (see text for detail). 


\subsection{Epigenetics Mechanisms in Placental Development}

Epigenetic mechanisms are involved in the regulation of gene expression both during development and in differentiated tissues [21,22]. These mechanisms include DNA methylation, histone modifications and biogenesis and action of noncoding RNAs (ncRNAs). They regulate gene expression by modulating the accessibility to DNA of transcription factors and other regulatory proteins. In addition, ncRNAs also regulate gene expression at a post-transcriptional level. Epigenetic mechanisms are essential for cellular differentiation and therefore development, as summarized in Table 1

Table 1. Epigenetic mechanisms in placental development.

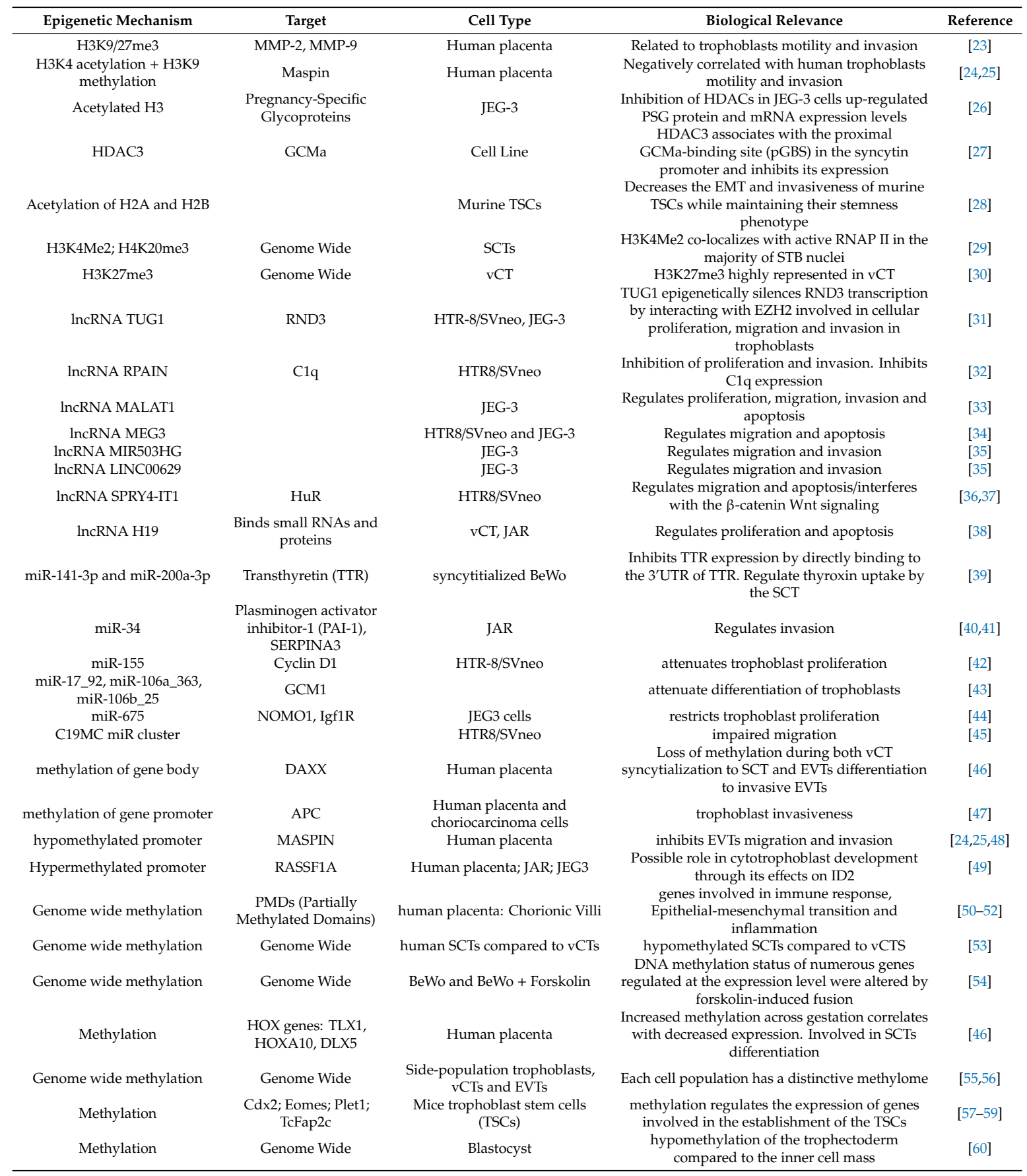




\subsubsection{DNA Methylation}

The best studied epigenetic mechanism in the placenta is DNA methylation, the covalent addition of a methyl group to a cytosine, usually in the context of cytosine-phospho-guanine (CpG) dinucleotides. Several reviews have been dedicated to the role of this mechanism in placental development $[10,12,61]$. Also, several high-throughput analyses have been performed to analyze the methylation epigenetics of the developing placenta (Table 2, Supplementary Table S1 for the details).

Table 2. Summary of DNA methylation studies in developing placenta using genome-wide approaches.

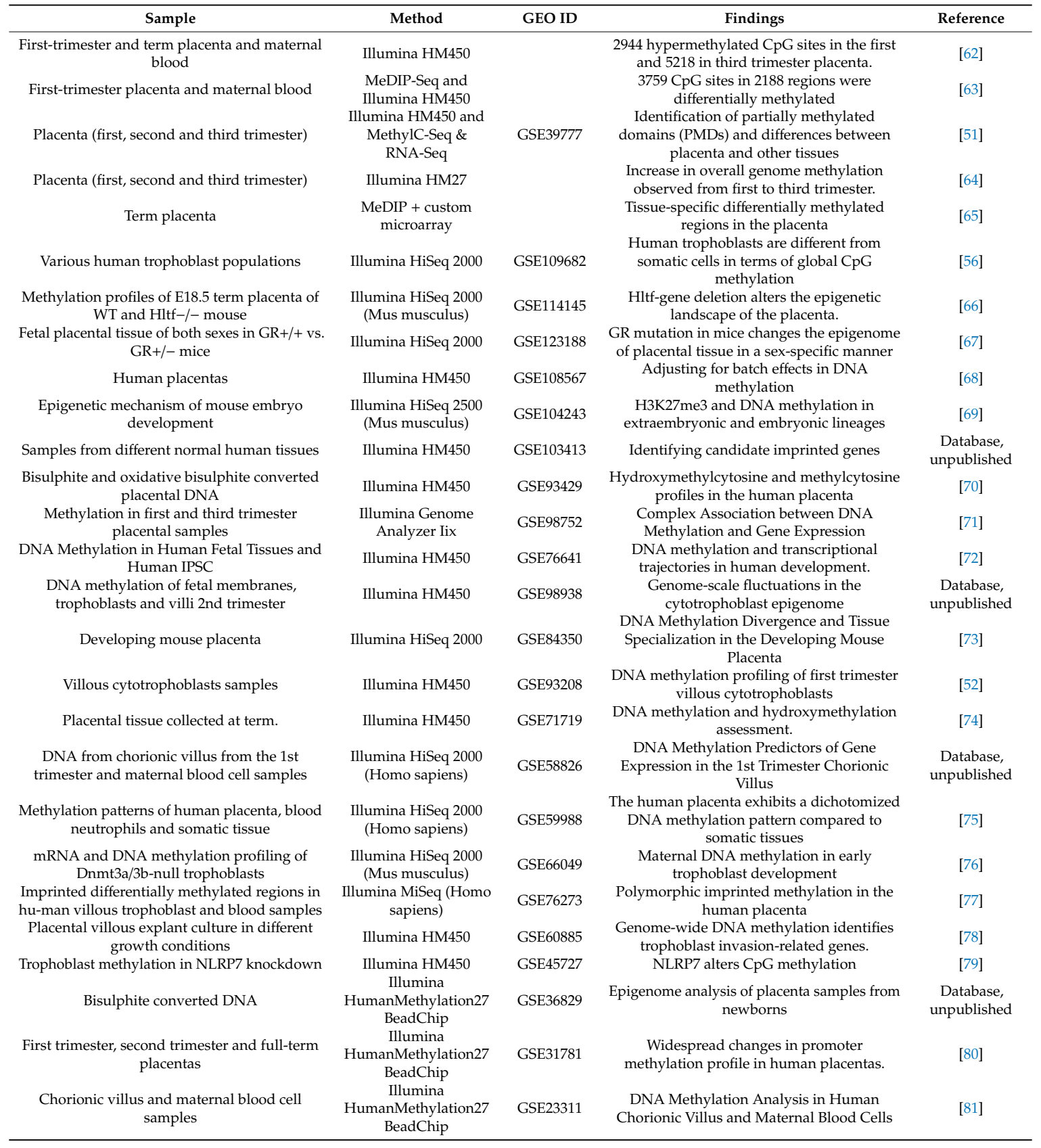

\section{Differentiation of Stem Cells}

Contrary to mice, a Trophoblast Stem Cell (TSC) population has not yet been clearly identified in humans, thus limiting our capacity to study the role of DNA methylation in the early stages of trophoblast differentiation. A recent study has addressed this question using a side-population trophoblasts, a candidate human TSC [55], isolated from first trimester placenta. The comparison of 
the methylomes of this side-population trophoblasts and the methylomes of vCTs and EVTs all isolated from the same first trimester placenta, showed that each population had a distinctive methylome [56]. In comparison to mature vCTs, side-population trophoblasts, showed differential methylation of genes and miRNAs involved in cell cycle regulation, differentiation and regulation of pluripotency. In addition, the comparison of the methylomes and transcriptomes of vCTs and EVTs revealed the methylation of genes involved in epithelial-mesenchymal transition (EMT) and metastatic cancer pathways, which could be involved in the acquisition of the invasive capacities of the EVTs. However, this study, as many others, failed to establish a systematic correlation between hypermethylation of the genes and downregulated expression. Therefore, the authors conclude that although $\mathrm{CpG}$ methylation is involved in the trophoblasts differentiation, it cannot be the only regulatory process.

\section{Regulation of Homeotic Genes}

Several studies have identified and established the importance of the transcription factors of the homeobox gene family (HOX) in the development of human placenta [82-86]. Most HOX genes have been found stably hypo-methylated throughout gestation, suggesting that DNA methylation is not the primary mechanism involved in regulating HOX genes expression in the placenta. However, these genes show variable methylation patterns across gestation, with a general trend towards an increase in methylation over gestation. Three genes (TLX1, HOXA10 and DLX5) present slightly increased methylation while their mRNA expression decreases throughout pregnancy, supporting a role for DNA methylation in their regulation [46]. Down-regulation of these genes using siRNAs specific for DLX5, HOXA10 and TLX1 in primary trophoblasts leads to loss of proliferation and to an increase in mRNA expression of differentiation markers, such as ERVW-1. This suggests that loss of these proteins is required for proper SCT development [46].

Placental Development and Cancer Pathways

The early steps of placentation are reminiscent of the invasive properties of malignant tumors. Studies on DNA methylation in cancer cells and placental cells have highlighted similarities in their epigenomes, particularly, a widespread hypomethylation throughout the genome and focal hypermethylation at $\mathrm{CpG}$ islands. Hypomethylation within the placenta is not uniform but occurs in large domains ( $>100 \mathrm{~kb}$ ) called partially methylated domains (PMDs) which are regions of reduced DNA methylation that cover approximately $40 \%$ of the placental genome [51]. PMDs are unique to a few different tissue types that include the placenta, cultured and cancer cells $[50,51,87]$. Placental genes within PMDs tend to be tissue-specific and show higher promoter DNA methylation and reduced expression as compared with somatic tissues [51]. A genome-wide comparison of DNA methylation changes in placental tissues during pregnancy and in 13 types of tumor tissues during neoplastic transformation revealed that megabase-scale patterns of hypomethylation distinguish first from third trimester chorionic villi in the placenta [52]. These patterns mirror those that distinguish many tumors from the corresponding normal tissues. The genomic regions affected by this hypomethylation encompass genes involved in pathways related to EMT, immune response and inflammation, all of them associated to cancer phenotypes. Moreover, the authors observed that hypomethylated blocks distinguish vCTs before 8-10 weeks of gestation and after 12-14 weeks of gestation. The analogy between early placentation and malignant tumors at the epigenetic level is further stressed by studies analyzing the methylation status of the promoters of several tumor suppressor genes (RASSF1A, SERPINB5 also known as APC and Maspin, respectively) in the developing placenta and human choriocarcinoma cell lines (JAR and JEG3) [25,49]. These studies show that promoter DNA-methylation regulates the expression of these tumor suppressor genes which in turn affects the migration and invasive capacities of the trophoblastic cells (As summarized in Table 1). 
2.3.2. Non-coding RNAs and Epigenetic Regulation of Placenta Development

Definition

A non-coding RNA (ncRNA) is defined as an RNA molecule that is not translated into a protein. Classes of non-coding RNAs include transfer RNAs (tRNAs) and ribosomal RNAs (rRNAs), small RNAs such as microRNAs (miRNAs), siRNAs, piRNAs, snoRNAs, snRNAs, exRNAs, scaRNAs and the long ncRNAs [88]. The role of these molecules in placental development, physiology and pathology has been recently reviewed in detail [89]. Here we will discuss solely the role of miRNAs and long ncRNAs in the epigenetic control of placental development.

\section{MiRNA and Normal Human Placental Development}

The miRNAs are single stranded RNA molecules of 19-24 nucleotides, which act primarily by degrading mRNA transcripts or inhibiting translation of miRNA in to proteins [90]. To date, more than 2000 human miRNAs have been discovered, which appear to regulate $50 \%$ of human RNAs [91]. A large number of miRNAs detected in the placenta are expressed from a gene cluster located on chromosome 19 (C19MC) [92,93]. This cluster includes 46 intronic miRNA genes that express 58 miRNA species. These miRNAs are primate-specific, and they are expressed almost exclusively in the placenta (and are thus termed trophomiRs). In the human placenta, the expression of C19MC miRNAs is detected as early as 5 weeks of pregnancy and the expression gradually increases as pregnancy progresses [94]. An imprinted, paternally expressed, CpG-rich domain has a regulatory role in C19MC expression [95]. This DMR, is hypermethylated in cell lines that do not express C19MCs [96]. The C19MC region contains genomic transposable elements called "Alu repeats", which have been implicated in recombination and gene duplication events. Because of their sequence complementarity it has been proposed that several C19MC miRNAs could be responsible of the targeting and degradation of transcribed Alu elements. Also, the C19MC miRNAs are expressed in embryonic and in stem cells but their expression drops considerably when these cells differentiate, which may indicate a role in the maintenance of an undifferentiated state [97-101]. Several members of the C19MC cluster are expressed at much higher levels in vCT compared with EVTs and overexpression of the C19MC cluster results in reduced migration of the extravillous trophoblast line HTR8/SVneo [45]. The chromosome 14 miRNA cluster (C14MC) is another miRNA cluster that is expressed in the placenta [102]. This cluster includes the miRNAs: miR-127, miR-345, miR-370, miR-431 and miR-665. These miRNAs have been involved in the regulation of the immune suppressive, anti-inflammatory response and also in the regulation of the ischemia/hypoxia response [103]. The expression of the C14MC members generally declines during pregnancy [104].

The miR-675 is expressed from the first exon of the H19 long non-coding RNA. Up-regulation of miR-675, which is controlled by the stress-response RNA-binding protein HuR, restricts murine placental growth. Deficiency of H19, promotes placental growth and miR-675 overexpression decreases cell proliferation, likely through targeting Igf1R [105]. Consistent with these findings, the expression of miR-675 rises toward the end of murine pregnancy, when placental growth decelerates. In addition, miR-675 restricts proliferation in JEG3 cells, likely through binding to the nodal modulator 1 (NOMO1) protein [44].

Several other miRNAs are likely involved in placental development by inhibiting genes associated to regulation of trophoblast fate, invasion and proliferation (Let-7a, miR-377, miR-145, members of the miR-17_92 cluster, members of the miR-106a_363 and miR-106b_25 clusters, miR-155, miR-34, miR-141-3p and miR-200a-3p) [106,107]. As additional examples of regulation, mir-431inhibits invasion of trophoblast cells by targeting the ZEB1 gene [108], miR-106a 303 inhibits trophoblast differentiation by targeting hCYP19A1 and hGCM1 [43], miR-34 targets SERPINA3, a key gene in a variety of biological processes and highly deregulated in placental diseases [41].

These miRNAs regulate diverse processes such as trophoblast physiology, proliferation and invasion (some mentioned in Table 1 and reviewed in Reference [107]). 
lncRNA and Normal Human Placental Development

Long non-coding RNAs (lncRNAs) are RNAs greater than 200 nucleotides in length that do not encode a protein product. They are expressed with cellular and temporal specificity and have been involved in many cellular events, including the regulation of gene expression, post-transcriptional modifications and epigenetic modifications, imprinting and X-chromosome inactivation [109]. They act as scaffolds (binding other RNAs or proteins), signals and antisense decoys and engage in transcriptional interference. Usually a single lncRNA has multiple functions. The function of lncRNAs in placental development is poorly understood, mostly inferred from studies on placental pathologies. Nevertheless, IncRNAs have been involved in a number of critical trophoblast functions, from proliferation, invasion and migration, to cell cycle progression [110]. H19 was one of the first lncRNAs to be discovered [111]. H19 is located within a large imprinted domain on chromosome 11, at 100 kb downstream of IGF2. H19 and IGF2 are reciprocally imprinted that is, for H19 only the maternal allele is expressed, while for IGF2, only the paternal allele is expressed [112]. H19 expression could be regulated by PLAGL1, a zinc finger transcription factor, in the human placenta [113]. Two major functions have been described for H19, specifically as a modulator for binding small RNAs and proteins [114] and as a source of the miRNA mir-675 (see above). H19 has variable levels of biallelic expression in the placenta (reports suggest between $9 \%$ and $25 \%$ expression occurs from the imprinted allele) until 10 weeks of gestation by which time H19 expression is mostly restricted to the maternal allele [115]. H19 expression is restricted to intermediate and vCT and is not found within SCTs in the human placenta. H19 down-regulation in trophoblast cells leads to inhibition of proliferation and apoptosis [116]. Many other lncRNAs have been involved in placental development, including lincRNA SPRY4-IT1, MIR503HG, LINC00629, MEG3, MALAT1, RPAIN and TUG1 [31-37]. The study of the expression of these lncRNAs during placental development and the manipulation of their expression in vitro in choriocarcinoma cell made it possible to infer their possible function in the context of placental development (Table 1).

\subsubsection{Histone Modifications in the Developing Placenta}

Histone modification is the process of modification of histone proteins by enzymes, including post-translational modifications, such as methylation, acetylation, phosphorylation and ubiquitination. Histone modifications participate in gene expression regulation by modulating the degree of chromatin compaction [117].

Our knowledge concerning the role of histones modification in human placentation is scarce and refers mostly to studies in mice. Methylation frequently occurs on histones $\mathrm{H} 3$ and $\mathrm{H} 4$ on specific lysine (K) and arginine (A) residues. Histone lysine methylation can lead to activation or to inhibition, depending on the position in which it is located. For instance, H3K9, H3K27 and H4K20 are considered as important 'inactivation' markers, that is, repressive marks, because of the relationship between these methylations and heterochromatin formation. However, the methylation of H3K4 and H3K36 are considered to be 'activation' marks [118,119].

The heterochromatin methylation marker H3K27me3 was found to be highly active in vCT. That was explained by rapid and transient repression of genes at the time of SCT formation. SCTs nuclei were also found enriched for H4K20me3 [30]. However, this report contrasted with another study reporting that the CTs were enriched with $\mathrm{H} 3 \mathrm{~K} 4 \mathrm{me} 3$ and that the SCTs were transcriptionally activated by the chromatin marker H3K4me2, which co-localized with active RNAP II in the majority of SCT nuclei [29]. In mouse and other mammals, H3 arginine methylation predisposes blastomeres to contribute to the pluripotent cells of the ICM, which appears to require higher global levels of $\mathrm{H} 3$ arginine methylation than the TE/trophoblast lineage [120]. Nevertheless, these lower modification levels in the trophoblast lineage are indispensable for normal placental development.

Acetylation, which in most cases occurs in the $\mathrm{N}$-terminal conserved lysine residues, is also an important way to modify the histone proteins, for example, acetylations of lysine residues 9 and 14 of histone $\mathrm{H} 3$ and of lysines 5, 8, 12 and 16 of histone H4 by Histone Acetylases (HATs). Acetylation is generally associated with the activation or opening of the chromatin. On the contrary, 
de-acetylation of the lysine residues by histone deacetylases (HDACs) leads to chromatin condensation and inactivation of gene transcription. Oxygen $\left(\mathrm{O}_{2}\right)$ concentrations strongly influence placental development partially through modifications of the histone methylation codes. Initially, the gestation environment is hypoxic and $\mathrm{O}_{2}$ concentration increases during development. Hypoxia-inducible factor-1 (HIF-1), consisting of HIF-1 $\alpha$ and ARNT subunits, activates many genes involved in the cellular response to $\mathrm{O}_{2}$ deprivation [121]. HIF-1 is also known to recruit and regulate HDACs [122,123]. Moreover, HIF-1 has been found to bind specific sites on the promoter of the H3K9 demethylases thereby inducing their expression. In particular, it induces JMJD1A and JMJD2A that remove dimethyl marks on H3K9me2, JMJD2B [124,125] which removes trimethyl marks (H3K9me3) and more weakly JMJD2C which converts H3K9me3 to me2 [126]. Studies in rodents have shown that HIFs have important roles in the regulation of TSCs differentiation by integrating physiological, transcriptional and epigenetic inputs. Thus, the crosstalk between HIF and the HDACs is required for normal trophoblast differentiation $[123,127]$.

Another example of histone modification during placentation, is the acetylation of histones $\mathrm{H} 2 \mathrm{~A}$ and H2B by the CREB-binding protein (CBP). CBP acts as an acetyltransferase that decreases the EMT and invasiveness of murine TSCs while maintaining the properties of stem cells [28].

Trophoblastic fusion depends on the regulation of GCMa activity by HATs and HDACs. Human GCMa transcription factor regulates expression of syncytin, which in turn mediates trophoblastic fusion. It has been demonstrated that CBP-mediated GCMa acetylation underlies the activated cAMP/PKA signaling pathway that stimulates trophoblastic fusion [27]. Human pregnancy-specific glycoproteins (PSG) are the major secreted placental proteins expressed by the SCTs and represent early markers of cytotrophoblast differentiation. Pharmacological inhibition of HDACs in JEG-3 cells up-regulated PSG protein and mRNA expression levels. This correlated with an increase in the amount of acetylated histone H3 associated with PSG promoter [26]. Combined acetylation at H3K9 and H3K4 methylation also activates Maspin, a tumor suppressor gene which is negatively correlated with human trophoblasts motility and invasion $[24,25]$. The invasive capacity exhibited by EVTs is attributed in part to the extracellular matrix degradation mediated by matrix metalloproteinases (MMPs) such as MMP-2 and MMP-9. Differential expression of these MMPs and their tissue inhibitors (TIMPs) has been associated to histone H3K9/27me3 [23].

\subsubsection{Imprinting and Placental Development}

Placentation and the Materno-Fetal Conflict

Pregnancy in Eutherian mammals is an immunological challenge as reviewed recently [128]. To note, an ancestral inflammatory response in pregnancy and parturition also exist in marsupials (metatherians), as recently observed [129,130]. Other mechanisms are equally conserved in the formation of the placenta, in particular the fusion mechanisms of cytotrophoblasts into syncytiotrophoblasts that are mediated by retroviruses, in eutherians as well as in metatherians [131].

Once the placenta is formed, it will allow nutrients to transit from the mother circulation to the fetal circulation. In the context of the maternal-fetal conflict hypothesis, tightly regulating the placentation process and limiting placental growth is crucial for the mother survival. The genes controlling this regulation are expected to be found different between viviparous and non-viviparous species. For this, mammals appear as an excellent model as a group of $\sim 4500$ species divided into egg-laying animals (prototherians, Platypus and Echidnaes, 5 species), animals with a short-lived placenta (metatherians, Marsupials $\sim 250$ species) and viviparous species with a long-lived placenta (eutherians, i.e., all the other mammals, where gestation length can be up to 22 months in the African elephant). One major difference found between the genome of placental species and non-placental species of mammals is the presence of imprinted genes only in the first group. 
Definition of Imprinted Genes and Links with Viviparity

Imprinted genes are genes that are expressed from either the maternal or the paternal allele, mainly through differentially methylation mechanisms. Their existence leads to dramatic phenotypic differences in animal hybrids according to the sense of the cross. For instance, interbreeding of lions and tigers results in two morphologically different animals, if the male is the lion or the male is the tiger, leading to a liger or a tigon, respectively [132]. While the tigon has a size like that of its parents, the liger is the largest existing felid (up to $>400 \mathrm{~kg}$ ) and several hypotheses have been raised to explain this fact, mostly connected to the existence of imprinted genes. Experimentally, in the 80s, Solter and Surani carried out nuclear transfer experiments that demonstrated in mice the necessity of a paternal and maternal genome to foster healthy development [133]. Androgenetic embryos lead to the production of a hypertrophic placenta while gynogenetic embryos had a very small placenta and a stunted embryo. Similarly, in humans, development from two paternal genomes leads to hydatiform moles, where the placenta is composed of grapelike vesicles, whereas parthenogenic development leads to the apparition of teratomas [134].

As far as we know today, imprinting is closely associated to viviparity. The sequencing of the platypus genome in 2008 [135] revealed syntenic regions that are relatively well conserved with the eutherian and marsupials, albeit no evidence of imprinted gene can be found in Monotremes. This may be since acquisition of imprinting in a species seems to be associated to the progressive acquisition of CpG islands (besides other mechanisms, such as chromosome translocations or retrotransposons insertions), that appear absent from the platypus genome [136,137]. In marsupials (metatherians), where the placenta is short-lived, the number of imprinted genes is more limited than in eutherian mammals. Two imprinted regions are well conserved between metatherians and eutherians such as the PEG10 and the H19-IGF2 regions [135]. Similarly, an exhaustive analysis of the transcriptome of chicken failed to identify imprinted genes, while allele specific expression does exist $[138,139]$. The evidence collected therefore strongly links these genes with the placenta presence. Besides, imprinted genes may have a strictly paternal or strictly maternal expression. Series of invalidation experiments in mice indicated that paternal genes tend to increase placental growth while maternal genes tend to limit this growth [140].

\section{Example of the H19-IGF2 Cluster; Cross Species Conservation of Imprinted Genes}

A well-known example of this is the H19-IGF2 cluster localized distally at 11p15.5 in humans and 7qF5 in mice. In both species, the structure of the locus is conserved (about 100 kilobases separating the two genes, with differentially methylated regions inside IGF2 and nearby H19). An IMC (Imprinting Control Region), located $3 \mathrm{~kb}$ from the starting point of $\mathrm{H} 19$ has also been identified, with seven binding sites for the ZNF transcription factor CTCF. H19 is expressed exclusively form the maternal allele, while IGF2 is expressed from the paternal allele. In mice, a placental specific promoter of Igf2 was discovered. The selective invalidation of this promoter [141] leads to a strong decrease of placental development and placental growth. By contrast, the invalidation of $\mathrm{H} 19$, leads to placental and fetal overgrowth [142]. Amongst other imprinted genes that affect placental and fetal growth besides H19 and IGF2 are paternally expressed genes, generally identified in mice (Peg1, Peg3, Rasgrf1, Dlk1) and maternally expressed genes (Igf2r, Gnas, Cdkn1c, Grb10).

Interestingly, in mice, the decoy receptor of Igf2, Igf2r is imprinted and with a maternal profile of expression. In humans, surprisingly, the imprinting status of IGF2R seem to be erratic, polymorphically imprinted according to the human individual analyzed. This was first published in 1993 [143] that showed that 2 out of 14 fetuses had an exclusive expression from the maternal allele. Recently it was shown that IGF2R is duly imprinted in macaques [144], showing that even in primates, the imprinting status can vary between relatively close species. Overall, it appears that many placental imprinted mouse genes are biallelic in their expression in humans [145]. Reciprocally, in a study aiming at identifying novel imprinted genes in the human placentas, we compared variants of the placental DNA versus those of cDNAs from the same placentas using SNP microarrays [146,147]. In addition to 
four known imprinted genes (IPW, GRB10, INPP5F and ZNF597), we could identify 8 novel imprinted genes in the human placentas (ZFAT, ZFAT-AS, GLIS3, NTM, MAGI2, ZC3H12C, LIN28b and DSCAM). Using a mouse cross allowing the following of the allelic origin, we found an astonishing variegation of the imprinting status: only Magi2 was imprinted in the mouse species.

Imprinted genes may have a general impact on the global methylation status of the placenta. For instance, recently a polymorphism located at the IGF2/H19 locus was shown associated to placental DNA methylation and birth weight in association with Assisted Reproductive Technologies usage [148]. Imprinted genes deregulation in the placenta is linked to placental diseases, as reviewed in References [149,150]. In a recent study, Christians and coworkers, analyzed a list of 120 imprinted genes in relation with global expression of 117 placental samples, including PE and Intra Uterine Growth Restriction (IUGR) cases [151]. The authors identified a significant correlation between birth weight and the expression level of imprinted genes but without significant differences between paternally versus maternally expressed genes. Imprinted genes were also more heavily deregulated in preeclampsia than other genes and in this case paternally expressed genes were down-regulated, while maternally expressed genes were up-regulated. The trend was similar for IUGR. Interestingly, the two human-specific microRNA clusters (C19MC and C14MC), both appear to be imprinted (paternally and maternally expressed) for C19MC and C14MC, respectively, clusters that have been duly studied by the team of Yoel Sadovsky $[45,89,152]$. Recently, we identified duplication in the 19q13.42 imprinted region encompassing the C19MC cluster [153], from a male 26 weeks fetus with severe IUGR, suggesting that a double dose of the miRNA could contribute to the disease. This suggests links between miRNA regulation, imprinting status and the putative consequences for fetal health and growth.

\section{Epigenetic Alterations in Preeclampsia}

\subsection{DNA Methylation Alterations in Preeclampsia}

Anomalies of DNA methylation in preeclampsia have been analyzed from different cellular sources. Besides the analysis of placental cells, investigators have analyzed circulating maternal blood cells or cell-free DNA, as well as maternal endothelial cells (much less accessible, though) and cord-blood white blood cells (of fetal origin). A list of genes of which methylation was found altered is presented as Table 3.

A summary of epigenetic mechanisms at work in PE is shown in Figure 2.

\subsubsection{Methylation Alterations in the Preeclamptic Placenta}

Common Alterations of Gene Expression in PE are Associated to Methylation Alterations

Numerous studies revealed altered expression of various genes in the pathological placentas (as synthesized previously [154]). These alterations of gene expression are partly explained by the existence of epigenetic deregulations. In PE, numerous methylation deregulations have been found in the pathological compared to control placentas, some studies (but not all) taking into account the gestational age, a recurrent issue when normal and pathological placentas are compared, for which there is often a more than 6 weeks difference [155-160]. The different techniques used to analyze methylation globally are presented in a previous review [161]. These epigenetic changes probably originate from the abnormal placental environment in PE (or IUGR), characterized by alternations of low oxygen tension and hyperoxia. As mentioned above, hypoxia per se induces the expression of the Hypoxia-Inducible factor (HIF1 $\alpha$ ), which binds to Hypoxia Responsive Element activating the transcription of various genes related with angiogenesis and metastasis-associated genes [162]. Overall, abnormal oxygen signaling in the placental context leads to increased concentrations of Oxygen Reactive Species (ROS) [163]. Oxidative stress may drive an accelerated ageing of trophoblast cells, which could be key to understand the origin of placental disorders. Indeed, several studies 
emphasized alterations of telomere length (a mark of ageing) in preeclamptic pregnancies, with a drastic augmentation of short telomeres in PE, especially in Early Onset PE (EOPE) [164-166]. This senescence may be induced by alterations of the management of oxidative stress [167-169]. The accelerated transformation of vCTs into SCTs will lead to a decrease life expectancy of the placenta and an alteration of its capacity to bring the gestation harmoniously to its normal term.
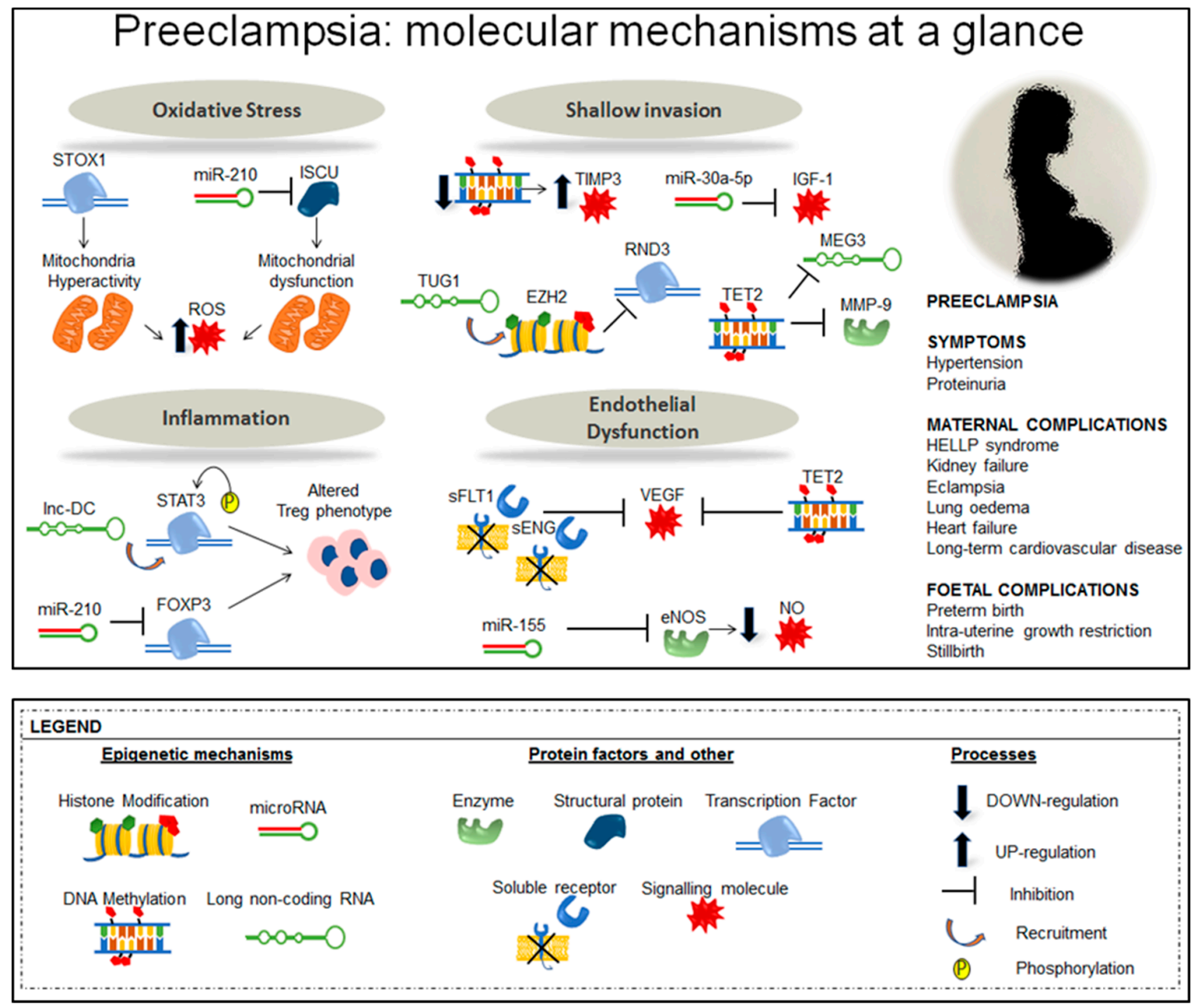

Figure 2. Overview of the molecular mechanisms at play in preeclampsia. Annotations: eNOS = Endothelial Nitric Oxide Synthase; EZH2 = Enhancer of Zeste Homolog 2; FOXP3 = Forkhead box P3; IGF-1 = Insuline-like Growth Factor 1; ISCU = Iron-sulfur cluster; Lnc-DC = Long non-coding RNA DC; miR-30a-5p = microRNA 30a-5p; miR-155 = micro-RNA 155; miR-210 = microRNA 210; MMP-9 = Matrix Metalloproteinase-9; NO = Nitric Oxide; RND3 = Rho Family GTPase 3; ROS = Reactive Oxygen Species; sENG = Soluble endoglin; sFLT1 $=$ Soluble fms-like tyrosine kinase receptor -1 ; STAT3 = Signal transducer and activator of transcription 3; STOX1 = Storkhead Box 1; TET2 = Tet methylcytosine dioxygenase 2; TIMP3 = TIMP Metallopeptidase Inhibitor 3; TUG1 = long non-coding RNA taurine-upregulated gene 1; VEGF = Vascular Endothelial Growth Factor.

It is well known that persisting environmental variations induce changes in the epigenetic marks, including DNA methylation. These marks can either be mere biomarkers or participate actively in regulating genes to overcome the changing environmental conditions (although gene expression changes are often disconnected from methylation alterations).

Overall, several of the genome-wide studies showed that the methylation profiles differ between early and late onset of preeclampsia (EOPE and LOPE), suggesting a different etiology between these two types of PE [170-173]. EOPE shows more pronounced genome-wide hypermethylation changes 
than LOPE, probably since it is caused by earlier alterations allowing the epigenetic reprogramming to install earlier, in reason of the earlier cellular stress [171,174].

Using the Illumina Methylation 450 BeadChip Array, Yeung and coworkers, identified 303 differentially methylated regions in PE, 214 hyper and 89 hypomethylated, after adjusting for gestational age. The genes located nearby or encompassing hypermethylated regions were enriched in gene-ontology (GO) terms such as "ATP transport", in KEGG pathways, such as "steroid hormone biosynthesis", "cellular senescence" and Reactome pathways, such as "Vpr-mediated induction of apoptosis by mitochondrial outer membrane (SLC25A6 and SLC25A4)". The annotation of clusters also revealed an alteration of clusters of homeobox genes, (especially HOXD genes), Wnt2 cell signaling; fertilization and implantation genes; reactive oxygen species signaling (NOX5) and cell adhesion (ALCAM) genes [158]. Amongst the most recent studies, Leavey and coworkers used a novel approach based upon bioinformatics to sort 48 human PE samples through their transcriptome profile before subjecting them to methylation analysis, using the Illumina Human methylation450K array. This made it possible to divide the preeclamptic cases into two groups associated to abnormal methylation marks nearby 'immunological' genes or more 'canonical' EOPE cluster, with for instance abnormally methylated CpG in FLNB, COL17A1, INHBA, SH3PXD2A, as well as in the gene body of FLT1 [160].

In 2015, the study of Zhu and coworkers [175] was the first to analyze simultaneously methylation and hydroxymethylation in the PE placentas. Hydroxymethylation results from the hydroxylation of methyl-Cytosine is a first step towards the active demethylation of DNA through the action of Ten+Eleven Translocation enzyme (TET) proteins, and could play an important role in gene expression regulation [176]. The authors showed that the methylation level is higher in gene promoters and gene bodies in PE versus control placenta. Surprisingly most of the clustering of the genes that were altered, either by methylation or by hydroxymethylation were associated with nervous system development, neurotransmitters, neurogenesis, which are presumably not relevant in a non-neural tissue as the placenta. Nevertheless, positive regulation of vasoconstriction was also enriched as a GO term, as well as regulation of nitrogen compounds, two pathways that have a clear biological sense in terms of placental diseases pathophysiology (association with vascularization and with the modulation of oxidative/nitrosative stresses).

Table 3. Differentially methylated genes in preeclampsia.

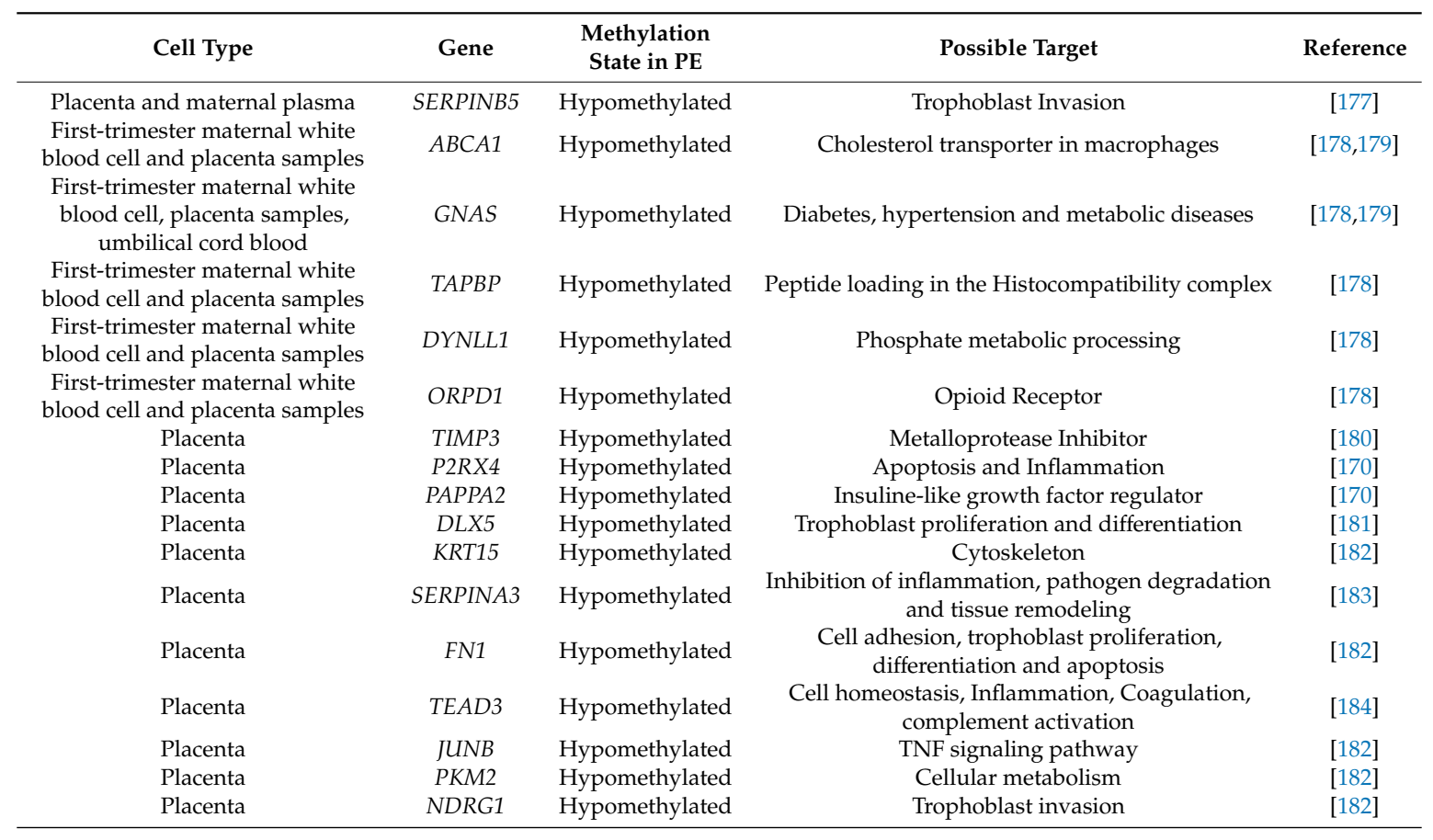


Table 3. Cont.

\begin{tabular}{|c|c|c|c|c|}
\hline Cell Type & Gene & $\begin{array}{l}\text { Methylation } \\
\text { State in PE }\end{array}$ & Possible Target & Reference \\
\hline Placenta & BHLHE40 & Hypomethylated & Inhibition of trophoblast differentiation & [171] \\
\hline Placenta & INHBA & Hypomethylated & Inhibition of trophoblast differentiation & [171] \\
\hline Placenta & HSD3B1 & Hypomethylated & Steroidogenic pathway & [184] \\
\hline Placenta & TEAD3 & Hypomethylated & Steroidogenic pathway & [184] \\
\hline Placenta & CYP19 & Hypomethylated & Steroidogenic pathway & [184] \\
\hline Placenta & $V E G F$ & Hypomethylated & Angiogenesis & [186] \\
\hline $\begin{array}{l}\text { Umbilical cord blood, placenta } \\
\text { samples }\end{array}$ & IGF2 & Hypomethylated & Embryonic development and fetal growth & {$[179,187]$} \\
\hline Placenta and Peripheral Blood & GNA12 & Hypomethylated & Blood pressure & [188] \\
\hline Placenta & $C A P G$ & Hypomethylated & Macrophage function & [189] \\
\hline Placenta & $C E B P \alpha$ & Hypomethylated & Transcription stimulation of LEP promoter & [191] \\
\hline Placenta & SH3PXD2A & Hypomethylated & Trophoblast invasion and podosome formation & [191] \\
\hline Placenta & NCAM1 & Hypomethylated & Trophoblast-trophoblast interactions and adhesion & [174] \\
\hline Cord blood samples & HSD11B2 & Hypomethylated & Cortisol transmission from the mother to the fetus & [192] \\
\hline Placenta & WNT2 & Hypermethylated & Placentation and cell signaling & {$[158,193]$} \\
\hline Placenta & SPESP1 & Hypermethylated & Fertilization & [158] \\
\hline Placenta & NOX5 & Hypermethylated & Reactive Oxygen Species signaling & [158] \\
\hline Placenta & $A L C A M$ & Hypermethylated & Cell Adhesion & [158] \\
\hline Placenta & $I G F-1$ & Hypermethylated & Placentation, trophoblast function, fetal growth. & [194] \\
\hline Placenta & SOX7 & Hypermethylated & Embryonic development and cell fate & [155] \\
\hline Placenta & $C D X 1$ & Hypermethylated & Trophoblast invasion restriction & [155] \\
\hline Placenta & CXCL1 & Hypermethylated & Chemokine inducer of angiogenesis & [155] \\
\hline \multirow[t]{2}{*}{ Placenta } & GATA4 & Hypermethylated & Placenta Growth & [173] \\
\hline & YWHAQ & Hypermethylated & Cellular response to reduce oxygen levels & [196] \\
\hline Placenta & TNF & Hypermethylated & $\begin{array}{l}\text { MMP-9 stimulation, Immune system activation, } \\
\text { cell survival, migration and differentiation }\end{array}$ & {$[174]$} \\
\hline Placenta & COL5A1 & Hypermethylated & Extracellular matrix & [174] \\
\hline Placenta & CDH11 & Hypermethylated & $\begin{array}{l}\text { Trophoblast anchoring to the decidua, } \\
\text { syncytiotrophoblast differentiation }\end{array}$ & [174] \\
\hline Placenta & $H L A-G$ & Hypermethylated & Maternal Immune tolerance and immune rejection & [197] \\
\hline
\end{tabular}

The major modifications of methylation occurring in preeclampsia are presented as Figure 3.

Limits of the Genome-Wide, Multicellular Approach for Preeclampsia Methylation Profiling

As mentioned earlier, a recurrent criticism of genome-wide comparisons between normal and PE placenta is linked to the fact that in general placental samples of PE patients are collected at earlier terms than controls. However, the existence of methylation profiles for control placentas throughout gestation [51] now allows to make the part between the effect of the placental ageing and the effects of the pathology per se. Other limits of these approaches are the complexity of the cell material, the variation between the degree of severity of the disease or the various statistical tests that are used in the different studies. Also, several studies have brought attention to the lack of reproducibility in high-throughput genomic, transcriptomic and epigenomic studies. This has been recently discussed by Komwar and coworkers in a recent study were they analyze the sources of variation in preeclampsia high-throughput studies an propose a methodology to ensure reproducibility and thus facilitate the integration of data across studies [198]. 


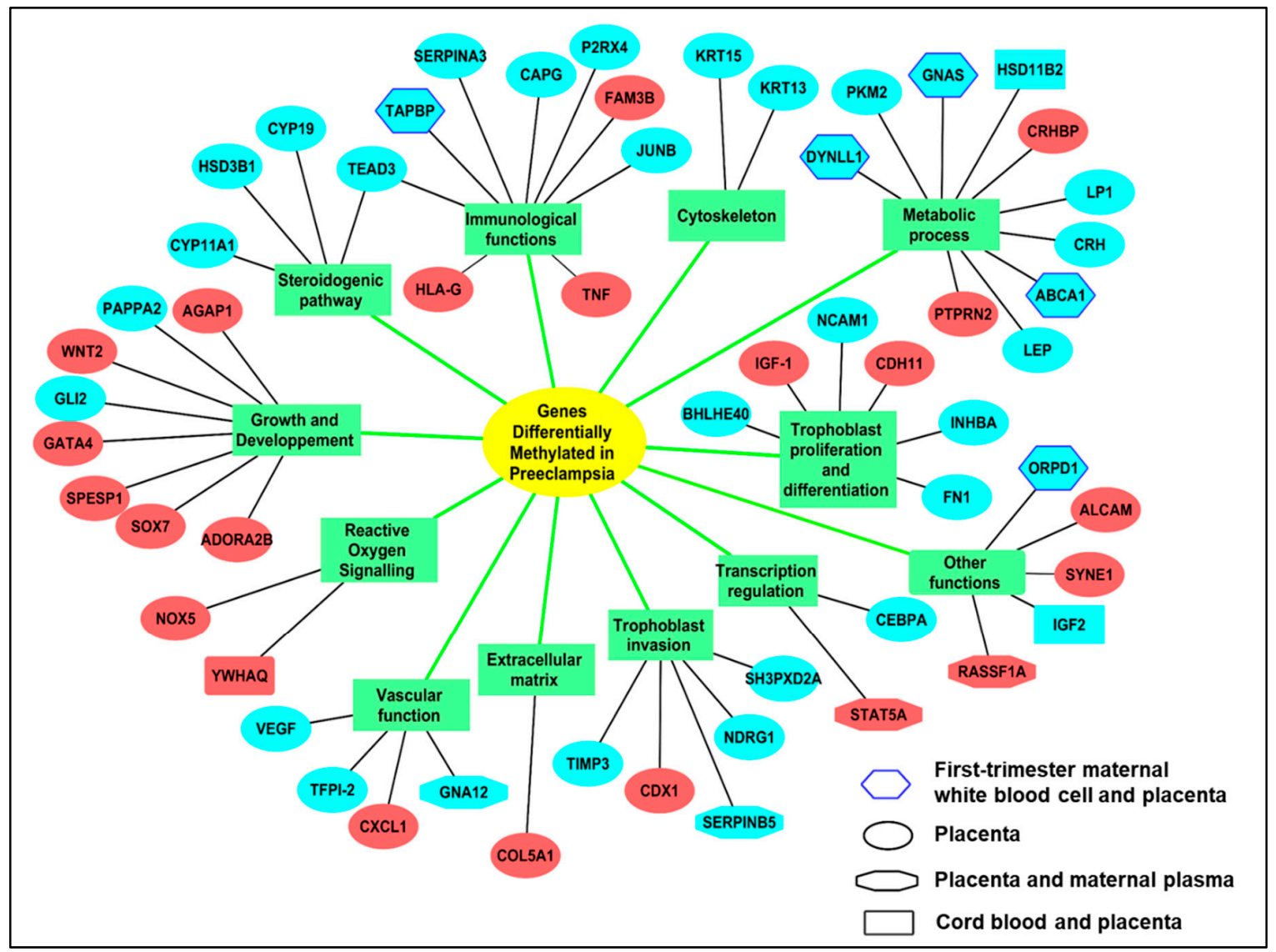

Figure 3. Overview of major methylation alterations in preeclampsia. The main pathways are shown in green boxes. The significant alterations in methylation may be associated either to increased or decreased gene expression (hypermethylated in red and hypomethylated in blue).

Single-Cell Analysis, the Next Frontier to Methylation Epigenomic Approaches

Gene-scale expression studies were recently carried out at the single cell scale [199] and have provided evidence of gene expression shifts during the CT, SCT and EVT differentiation steps, as well as, allowed the reconstructions of differentiation trajectories. This has also been analyzed by genome-scale DNA methylation analysis. Gamage and coworkers have analyzed by RRBS side population trophoblasts, CTs and EVTs from human first trimester placentas [56]. Forty-one genes involved in EMT and metastatic cancer pathways were found methylated between CT and EVTs, possibly contributing to the invasive phenotype of these cells. In the BeWo cell model where fusion can be induced by forskolin, RRBS analysis performed before and after fusion, showed altered methylation of genes involved in cell differentiation and commitment, together with a gain in transcriptionally active histone marks such as H3K4me3 [54]. Such approaches are for the moment difficult to transpose to placenta pathophysiology. Instead, several systems where methylation influences normal placental function have been studied. As an example, we present below the epigenetic regulation of genes involved in placental invasion and PE.

An Example of Specific Gene Alterations of Methylation: Regulation of Invasion

MMPs are well-characterized proteins involved in trophoblast invasion and angiogenesis during pregnancy. They constitute a family of $23 \mathrm{Zn}^{2+}$ and $\mathrm{Ca}^{2+}$-dependent proteases that degrade the extracellular matrix. This family of proteins presents abnormal concentration and behavior in placental diseases such as PE [200], placenta accreta and placenta percreta [201,202]. This has been recently reviewed for preeclampsia [203]. A decreased level of MMP-2 and MMP-9 reduces the remodeling of 
spiral arteries in early gestation. Besides, other MMPs, such as MMP-1 and MMP-14, may also have a role in this disease. Epigenetic mechanisms are at work for controlling MMP gene expression.

$\mathrm{Li}$ and coworkers observed that TET2 is involved in the demethylation of the MMP-9 promoter, this being associated to the downregulation of the protein and contributing to trophoblast shallow invasion [204].

TIMP3, a MMP inhibitor, shows the highest methylation reduction (over 15\%) in EOPE compared to control placentas with an inverse correlation between methylation level and gene expression suggesting an increased transcription of TIMP3 in PE placentas $[180,189]$. Low levels of TIMP3 lead to poor invasion of the trophoblast and placenta hypoperfusion. Moreover, TIMP3 may be able to inhibit angiogenesis by blocking vascular endothelial growth factor binding to its receptor contributing to impaired placenta blood vessels development. Also, genetic variations of the gene have been associated with cardiovascular disorders and hypertension.

\subsubsection{Maternal Blood Epigenetic Marks in Preeclampsia}

Alterations in the levels of many plasma and serum proteins have been associated with PE. In 2013, White and coworkers showed that PE was favoring hypermethylation in white blood maternal cells using the methylation-27k arrays from Illumina [205]. GRIN2b. GABRA1. PCDHB7 and BEX1 were found differentially methylated, with an enrichment of the neuropeptide signaling pathway. The re-analysis of methylation of genes known to be involved in PE revealed that in maternal circulating leukocytes, CPG sited from 4 genes associated with PE, POMC, AGT, CALCA and DDAH1, showed differential methylation in PE compared to control, with moderate methylation differences $(<6 \%)$ [206]. These 4 genes are known to alter immunomodulation and inflammatory response, suggesting that at least alterations of the placental physiology in preeclampsia have epigenomic consequences on maternal circulating cells.

During pregnancy, 3 to $6 \%$ of cell-free DNA in the maternal blood plasma is derived from the placenta. Oxidative stress in PE leads to increased trophoblast apoptosis and the release of SCT microparticles and a five to ten-fold increase in circulating fetal DNA in the maternal bloodstream compared with control counterparts $[207,208]$. These free fetal molecules and their methylation status have been proposed as a non-invasive biomarker of fetal and placental pathologies before the onset of symptoms. This has been shown for Maspin, for which the unmethylated version have a median methylation more than 5.7 fold higher in PE than control pregnancies $[209,210]$. Another epigenetic marker of preeclampsia is the methylation of RASSF1A (Ras Association domain-containing protein 1) promoter $[177,211,212]$.

\subsubsection{Maternal Endothelial Cells}

There is limited access to maternal vessels in pregnancy, nevertheless DNA methylation was assessed from this material in 2012 using the 27K methylation array of Illumina [213]. From 14.495 genes interrogated by the array, 65 genes were identified as hypomethylated in PE. Clustering leads to identify biological processes such as smooth muscle contraction, thrombosis, inflammation, redox homeostasis, sugar metabolism and amino acid metabolism. These alterations of the maternal endothelium suggest potential effects on cardiovascular life of the mother after preeclampsia. Focusing on collagen metabolism, the authors revealed an increased expression of MMP1 and MMP8 in vascular smooth muscle cells and infiltrating neutrophils of omental arteries of preeclamptic women, which was associated with reduced methylation in the promoters of both genes in pathological patients compared to control patients [213]. In the same study, several other MMPs, showed reduced hypomethylation in PE patients albeit with lower significance [214,215]. Moreover, pregnant women under dietary supplementation may restore the reduced methylation in the promoters of these genes and be protected against the development of PE. Interestingly, all these MMPs genes are located in chromosome 11, which may be indicative of a specific sensitivity of this chromosome to epigenetic changes caused by oxidative stress during the development of the pathology. The same team reported 
the reduced methylation in the promoter region of TBXAS1 gene in correlation with increased gene and protein expression of thromboxane synthase in vascular smooth muscle, endothelium and infiltrating neutrophils [215]. Increased levels of thromboxane synthase induce the overproduction of thromboxane $\mathrm{A} 2$, a potent vasoconstrictor and platelet activator, contributing to hypertension and coagulation abnormalities classically related to PE.

\subsubsection{Cord Blood Cells}

In 2014, Nomura and coworkers analyzed the global methylation profile of cord blood cells using the LUMA technique [161] and failed to observe an actual difference but with a limited number of controls samples (5) [216]. Genome-Wide Methylation analysis using the 450K microarray tool on neonatal cord blood DNA showed a significant genome-scale hypomethylation in neonatal cord blood DNA associated with EOPE, with 51,486 hypomethylated and 12,563 hypermethylated CpGs [187]. In this study the most differential methylated genes were associated with inflammatory pathways, cholesterol and lipid metabolism, including IL12B, FAS, PIK31 and IGF1. Deregulation of both metabolic pathways may increase the risk of cardiovascular diseases in the fetus [187]. The same microarray approach allowed to identify 5001 mostly hypermethylated regions in umbilical cord white blood cells and 869 mostly hypomethylated regions in the placenta [217]. In the cord blood cells, the gene networks enriched were involved in cardiovascular system development, cell cycle, cancer, cell morphology, infectious diseases, suggesting specific alterations that could have long-term consequences on the fetal health.

Some studies focused on mitochondrial DNA, showing hypomethylation in PE cord blood cells. The most affected loci are keys in mitochondria functionality: D-loop (control of mitochondrial DNA replication), Cytochrome C oxidase subunit 1 gene (respiratory chain) and TF/RNR1 locus (necessary for protein synthesis) [218]. Increased copy of mitochondria is observed in the placenta and maternal blood during PE suggesting an adaptive response to stress $[219,220]$. This is also observed in mouse models of PE [221]. Hypomethylation in the D-loop may lead to increased mitochondrial replication explaining the pathological increase of mitochondrial DNA. Methylation assay in endothelial colony-forming cells present in cord blood from PE presents differential methylation level in genes related to RNA metabolic processes, cellular protein modification processes and in positive regulation transcription, as assessed with the EPIC Illumina array, interrogating over 850,000 CpG [222]. However, at later passages, an increased number of genes are abnormally methylated. This suggests that preeclampsia may drive an altered epigenetic program in endothelial cell precursors that will be the building bricks of the newborn vascular system and program later complications.

\subsection{Non Coding RNAs}

Non-coding RNAs have been found to be differentially expressed in preeclampsia by a number of sources. Some studies have focused on investigating differential expression patterns between PE placental samples of different severities versus control groups looking for miRNAs or lncRNA [223-226], without generally identifying consensual signatures. With the aim of identifying potential biomarkers that could be used diagnostically to predict preeclampsia onset, many groups have set out instead to identify molecules differentially expressed in the plasma of patients, which could potentially be detected by mean of a simple blood test [227]. IncRNA and miRNA are the two classes of non-coding RNAs that have dominated the scene of non-coding molecules in preeclampsia. Other classes of non-coding RNAs have been identified, such as circular RNAs, that appeared recently in the context of PE development and future research will help understand the role of these molecules in the regulation of gene expression and disease [228].

\subsubsection{LncRNAs in Preeclampsia}

Long non-coding RNAs are RNA molecules longer than 200 nucleotides which are involved in regulation of cell function through a wide range of mechanisms. IncRNAs are expressed in the nucleus 
as single stranded RNA molecules, which can either function in their native form or undergo maturation through the addition of a $5^{\prime}$ cap and polyA tail; however, they are never translated into a protein product [229]. They regulate cell function by a wide range of mechanisms: alteration of the stability of target mRNAs, direct recruitment of chromatin modification enzymes, segregation of transcription factors through specific binding sites contained within the lncRNA sequence, warehousing miRNA as 'miRNA sponges', a function shared with circular RNAs [230]. For a complete overview please see Reference [231].

Transcriptomic analyses of placenta and decidua total RNAs allowed identifying differentially expressed lncRNAs between PE and control patients, often with a difference between EOPE and LOPE $[228,232,233]$. Most of these IncRNAs had been previously identified in the field of cancer research, often associated with cell proliferation, migration and invasion [234]. As mentioned above, given the parallels between the features of cancer cells and the trophoblasts during placentation such as fast proliferation of the trophoblast, migration and invasion of the maternal tissues, immunotolerance [235-238], this did not come as a surprise and has prompted extensive in vitro research to elucidate the roles of these lncRNAs in trophoblast physiology.

In the present review, we will focus on a few IncRNAs that have been well characterized: MALAT-1, MEG3, RNA-ATB. Finally, we will give a brief overview on how in PE some lncRNAs regulate gene expression by altering chromatin methylation state of their target genes, through direct recruitment of histone methyltransferases, bringing as examples PVT1, TUG1 and DIAPH2-AS1. H19 was discussed above for its important role in placental development and miRNA encoding lncRNA.

\section{MALAT-1}

Metastasis associated lung adenocarcinoma transcript-1 (MALAT-1) was firstly identified in lung cancer; it is a lncRNA of over $8 \mathrm{~kb}$ [239]. MALAT-1 normally localizes in the nucleus where it forms nuclear aggregates called speckles involved in the regulation of splicing factors availability [240]. MALAT-1 is overexpressed in placental pathologies associated with uncontrolled trophoblast invasion [241], which prompted Chen and coworkers [33] to investigate its expression in PE. Comparing RNA levels in 18 PE placentas with matched controls, MALAT-1 was found significantly downregulated in PE placentas. Overexpression and downregulation of MALAT-1 in JEG-3 regulates cell proliferation and invasion, while inhibiting apoptosis [33]. These findings suggest that MALAT-1 deregulation could lead to poor invasion of the maternal endometrium, affecting the spiral arteries' remodeling and placenta development. Li and coworkers [242] have shown that the role of MALAT-1 is not restricted solely to the trophoblast but has a key role in regulating the angiogenesis and vascularization of the maternal decidua and fetal umbilical vasculature. MALAT-1 is expressed by mesenchymal stem cells (MSCs) in the maternal decidua and in the umbilical cord. These cells are pluripotent progenitors which are able of self-renewal and proliferation, differentiate to promote tissue regeneration, form de novo vasculature, angiogenesis and regulate immune system responses [243]. Li and coworkers (2017) observed a decreased MALAT-1 expression in MSCs from decidua and umbilical cord of preeclamptic pregnancies and set out to investigate its function in these cells. Similarly, MALAT-1 promotes proliferation and protects from apoptosis in isolated MSCs. Interestingly, coculture of MSCs with trophoblast cell line HTR-8/SVneo clearly showed how MALAT-1 overexpression could promote migration and invasion of the trophoblasts towards the MSCs layer. Coculture of the endothelial cell line HUVECs (Human Umbilical Vein Endothelial Cells) in supernatant obtained from MSCs which either expressed or had downregulated MALAT-1 showed how MALAT-1 promotes tube formation this process being dependent on Vascular Endothelial Growth Factor secretion. Finally, MALAT-1 over-expression increased the levels of the IDO protein, which activated macrophage maturation, proving its role in immune system regulation. These findings combined with the work of Chen and coworkers (2015) beautifully illustrates how MALAT-1 has a symmetric regulatory function in placentation: on the one hand, it promotes trophoblast proliferation, invasive and migratory potential and on the other hand, its expression in MSCs cells helps to attract and promote trophoblast 
invasion, stimulates tube formation, promotes angiogenesis and vascularization. Increase in Reactive Oxygen Species caused MALAT-1 and VEGF downregulation in MSCc exposed to oxidative stress in a dose-dependent manner [242]. MALAT-1 downregulation in preeclampsia could therefore have a huge impact on placentation and further development of the placenta over the course of gestation. It is possible that a first triggering event maybe of immunological nature, causes an increase of oxidative stress during implantation which will then alter the expression level of many targets, including MALAT-1; based on the data, this consequent deregulation would have an impact on both trophoblast and MSCs physiology, culminating in preeclampsia.

\section{MEG3}

Maternally Expressed 3 (MEG3) is an imprinted lncRNA which is expressed in many different cell types and tissues and acts as a tumor suppressor and is downregulated in many types of cancer. Physiologically, MEG3 acts by stabilising p53 and activating apoptotic responses [244]. Zhang and coworkers [34] analysed MEG3 RNA levels in 30 placentas from preeclamptic women, compared to 30 control samples and found a statistically significant $80 \%$ downregulation. These results were consistent with those of Yu and coworkers [245] studying a cohort of 20 preeclamptic and 20 control placentas, finding that MEG3 RNA was only $28 \%$ of the RNA levels of the control group. To elucidate in more detail the function of MEG3 in placenta, Zhang and coworkers (2015) overexpressed MEG3 in two trophoblast cell lines (JEG3 and HTR-8/SVneo), showing enhanced antiapoptotic effects, while downregulation of MEG3 increased the apoptotic cells. Analysis of protein markers showed how MEG3 downregulation increased the levels of pro-apoptotic proteins such as Caspase-3 and Bax. These results contrast with what is observed in cancer, where MEG3 expression is rather associated with the activation of proapototic pathways, possibly suggesting a different mode of action of MEG3 in these cell types. Yu and coworkers [245] focused on the link between MEG3 expression and endothelial-mesenchymal transition (EMT). During implantation and placentation, the trophoblasts undergo EMT in order to be able to migrate and invade the maternal tissues. MEG3 downregulation correlated with increased E-cadherin levels and downregulation of mesenchymal markers such as $\mathrm{N}$-cadherin, vimentin, slug (encoded by the gene SNAI2), in placental RNA and protein extracts, placental sections and in vitro tests (HTR-8/SVneo trophoblast cell line). Changes in MEG3 expression did not influence proliferation but MEG3 overexpression promoted migration and trophoblasts invasion through matrigel matrixes [34,224]. Altogether, MEG3 protects from apoptosis, promotes migration and invasion by regulating endothelial-mesenchymal transition in trophoblast cells and therefore its downregulation possibly affects trophoblast invasion and placentation, playing a key role in preeclampsia. Consistently, the imprinting control region (IG-DMR) of the DLK1-MEG3 cluster was very recently found hypermethylated in human umbilical veins from preeclamptic pregnancies, with an altered expression of both imprinted genes, a lower secretion of nitrite, VEGF and a higher secretion of endothelin 1 (ET1) all factors able to mediate pathological mechanisms in the offspring from preeclampsias [246].

\section{RNA-ATB}

As with many other lncRNAs, IncRNA-activated by TGF $\beta$ (RNA-ATB) was first discovered in cancer, upregulated in hepatocellular carcinoma, it promotes cell proliferation, migration and invasion [247]. It has been reported that in hepatocells RNA-ATB is expressed in response to TGF $\beta$ and in fibroblasts; it can create positive feedback regulation by promoting TGF $\beta$ paracrine release. Lnc RNA-ATB was found to be significantly downregulated in placental samples from women with preeclampsia. Moreover patients with EOPE showed an even stronger deregulation [248]. Given the proliferative, invasive and migratory features of trophoblasts and in particular extravillous trophoblast, Liu and coworkers (2017) investigated lncRNA-ATB function in trophoblast cell line HTR-8/SVneo, which is a standard in vitro model of extravillous trophoblast. While overexpression of lncRNA-ATB increased the proliferative, migratory and invasive potential of HTR-8/SVneo cells, the downregulation 
caused a steep decrease in proliferation, migration and invasion, proving that this gene has an important role on the physiology of the extravillous trophoblast and that its deregulation could explain an aberrant implantation and endometrium invasion in preeclampsia, potentially being linked to incomplete spiral artery remodeling. Whether RNA-ATB regulates trophoblast function through the interaction with members of the miR200 family is yet to be determined. However, increased miR200 has been found to affect the development of endometrium receptivity, negatively impacting implantation [249]. In labor, miR200 is upregulated in the human uterus and has been associated with pre-term labor in murine studies [250]. It seems likely that an interaction between RNA-ATB and miR200 is required for correct placental development, gestation and delivery.

PVT1, TUG1 and DIAPH2-AS1: Regulating Gene Expression through Recruitment of Chromatin Remodeling Complexes

lncRNAs work through different mechanisms, depending on the specific lncRNA, the cell type, the downstream targets [231]. In the past few years a few IncRNAs have been identified in preeclampsia as potential modulators, among which PVT1, TUG1 and DIAPH2-AS1 adopt the same mechanism of action. IncRNA TUG1 is downregulated in preeclamptic placentas. Interference of TUG1 in trophoblast cell lines (JEG3 and HTR-8/SVneo) negatively affected cell proliferation and growth, migration and invasion, network formation, while it increased apoptosis [31]. Transcriptome analysis by RNA-sequencing of HTR-/SVneo cells in which TUG1 was downregulated showed a prevalence of affected genes involved in cell growth, migration and apoptosis. Xu and coworkers (2017) identified RND3 as main downstream factor involved in the phenotypic effects of TUG1 downregulation. RND3 mRNA and protein levels were strongly upregulated in response to TUG1 interference in vitro and RND3 mRNA was upregulated in preeclamptic placenta. RND3 is also known as RhoE, a GTPase that acts as a tumor suppressor, negatively regulating proliferation, migration and invasion [251]. In vitro experiments beautifully elucidated the mechanism by which TUG1 modulates RND3 expression-TUG1 directly interacts with the histone modification factor Enhancer of Zeste Homolog 2 (EZH2) and recruits it to the RND3 promoter, where EZH2 drives the silencing of RND3 by tri-methylating H3K27, resulting in strong RND3 downregulation [31]. A year later, $\mathrm{Xu}$ and coworkers [252] identified another lncRNA PVT1, strongly downregulated in preeclamptic placenta, whose downregulation negatively affects proliferation and increases apoptosis of trophoblast cell lines. PVT1 was found to recruit EZH2 to the promoter of the transcription factor ANGPTL4, driving its repression by increase in repressive chromatin markers: this could partially explain the phenotypic effects of PVT1 deregulation. Feng and coworkers [253] uncovered a complicated regulatory network behind PAX3 deregulation in preeclampsia which is linked with decreased proliferation, invasion and migration of trophoblast cells [254]. PAX3 is a transcription factor downregulated in preeclamptic placentas and this correlates with DNA hypermethylation of the promoter region [171,254]. In this study, Feng and coworkers (2019) found that in preeclamptic placentas lncRNA DIAPH2-AS1 is upregulated along with the transcription factor HOXD8. In vitro experiments in HTR-8/SVneo cells clarified the regulatory network: under hypoxia the transcription factor HOXD8 is upregulated and induces expression of the lncRNA DIAPH2-AS1. DIAPH2-AS1 recruits lysine-specific demethylase 1 (LSD1) to the promoter of PAX3 where it alters the chromatin modification state, decreasing methylation of Histone H3. LSD1 can also modify DNA methyl-transferase 1 (DNMT1), stabilizing it. ChIP experiments showed enrichment of LSD1 and DNMT1 at the PAX3 promoter, which correlated with increased DNA methylation and mRNA repression. Interference of DIAPH2-AS1 was enough to reverse the phenotype and increase PAX3 levels [253]. These studies underscore that different epigenetic mechanisms regulate gene expression. It is possible that certain mechanisms are favored in different cell types and future studies will help identify the conserved regulatory networks that plays a role in the etiology of preeclampsia. 


\subsection{2. micro RNA and Preeclampsia}

microRNAs in Preeclampsia

The first study on microRNAs (miRs) in preeclampsia was published in 2007. In this study, the expression levels of a subset of 157 miRNAs expressed in the placenta were tested by qRT-PCR in human placental samples from pregnancies without any complications, with PE, and with PE and small for gestational age (SGA) outcomes. 153 miRNA were detected in the placenta RNA samples and three of them were found to be upregulated in PE: miR-210, miR-155, miR-200b [255]. The first global transcriptomic analysis of microRNAs was performed with 20 PE placental samples and 20 controls, with microarray technology by Zhu and collaborators in 2009. Comparing gene expression profiles of the severe PE group with controls, 11 microRNAs were upregulated and 23 downregulated. Among them, many microRNAs are organized in chromosomal clusters: downregulated clusters are found in 13q31.3, 14q32.31, Xq26.2, Xq26.3, while upregulated clusters are found in 19q13.42 suggesting co-regulation profiles [256]. An integrative analysis was conducted comparing distinct datasets with the aim of identifying microRNAs-transcripts regulatory networks in preeclampsia. resulting in the construction of a map of putative microRNA-gene target interactions in developmental process, response to nutrient levels, cell differentiation, cell junction, membrane components [257].

Although many studies followed, most of them aimed at identifying differentially expressed miRs in placenta and in plasma samples from PE women. Fewer studies have focused in other cell types present in the placenta. For example, in fetal endothelial cells downregulation of miR-29a-3p and miR-29c-3p and upregulation of miR-146a is observed in PE patients [258]. Both miR-29a and miR-29c show proangiogenic functions by stimulating HUVECs proliferation and tube formation through VEGFA-induced and FGF2-induced cell migration pathways [259]. However, other studies suggest an antiangiogenic role of miR-29c through downregulation of the IGF-1 proteins at the post-transcriptional level $[260,261]$. On the other hand, miR-146a inhibits the de-novo formation of blood vessels in-vitro and reduces tube formation ability in HUVECs $[260,261]$. The study of the role that miRs may have in the different cell types present in the placenta is indispensable to understand the role of this molecules in the development of the disease. In the long term, it has also been shown that miRNA profiles in the neonate is altered following an hypertensive pregnancy; for instance the level of mir-146a at birth predict microvascular development three months later [262].

Many studies followed, aimed at identifying differentially expressed miRs in placenta and in plasma samples from PE women.

In this review, we will discuss the most well characterized microRNAs miR-210, miR-155 and give an overview of some of the research that has been carried out on circulating microRNAs, given their potential as clinically relevant biomarkers.

$\operatorname{miR}-210$

miR-210 is a microRNA involved in the regulation of mitochondrial function and hypoxia response. It has been well characterized, in placentas as well as in different cancer and tissue types [263]. Most of the knowledge on the regulatory pathways that involve miR-210 comes from oncology research. miR-210 has been soon identified as one of the early hypoxia-response miRs, being directly regulated by the Hypoxia inducible factor $1 \alpha$ (HIF-1 $\alpha)$ [264]. Under hypoxic conditions, miR-210 alters mitochondrial function promoting a metabolic switch to glycolysis. This is achieved by negative targeting of genes involved in the electron-transport chain, namely iron- sulfur cluster scaffold homolog (ISCU) and cytochrome $\mathrm{C}$ oxidase assembly protein (COX10). As a result, miR-210 also increases the levels of Reactive Oxygen Species (ROS) [265]. Under hypoxia, miR-210 and HIF-1 $\alpha$ establish a positive feedback regulation that maintains expression of both factors. This is achieved by miR-210 downregulation of the mRNA of Glycerol-3-Phosphate Dehydrogenase 1-Like, which would otherwise contribute to targeting HIF $1 \alpha$ to the proteasome for degradation. Conversely, stabilized HIF $1 \alpha$ directly activates miR-210 expression [266]. 
In endothelial cells, miR-210 is involved in regulating angiogenesis and vascularization which are fundamental processes in placenta development. Hypoxia causes miR-210 activation which protects endothelial cells from apoptosis and stimulates chemotaxis driven by VEGF, migration and tube formation [267]. In preeclampsia, miR-210 was first identified as upregulated in placenta samples by Pineles and collaborators (2007) using qPCR. In the first comprehensive study carried out with microarray technologies, miR-210 was consistently found upregulated in placenta of severe preeclamptic women, however in mild preeclampsia it was found to be downregulated, which might suggest different mechanisms at play or rather different metabolic states of the placenta, with a more pronounced ischemia in severe preeclamptic placentas [256]. Moreover, subsequent analyses identified significantly upregulated miR-210 in plasma samples from patients with preeclampsia [181]. In the context of PE miR-210 is involved in the mitochondrial dysfunction observed, which causes metabolic imbalance, excessive ROS production and cell damage. Similarly to what happens in cancer, miR-210 negatively regulates ISCU which is downregulated in preeclampsia samples, directly affecting mitochondrial architecture and functionality [268-270]. The deregulation of miR-210 was also found in the placentas of mice from a preeclamptic model [134].

miR-210 is also an important modulator of trophoblast phisiology. In vitro studies using isolated primary trophoblasts and trophoblast cell line JAR, proved how hypoxia induces an increase in miR-210 levels. Artificial overexpression of miR-210 in JAR cells caused a significant downregulation of migration and invasion. In trophoblast cells, hypoxia and ROS can activate HIF1 $\alpha$ but more importantly NFK-B p50-which si found upregulated in preeclamptic placenta tissues. NFk-B p50 binds a consensus sequence in the miR-210 promoter, activating its expression. In trophoblasts, miR-210 interacts with a perfect match with the 3'-UTR of the transcription factor homeobox-A9 (HOXA9), causing both degradation of the mRNA and downregulation of translation. Another direct target is Ephrin-A3 (EFNA3), a ligand of the Ephrin binding receptors, in this case miR-210 binds the 3'UTR of the gene with an imperfect match, causing only translational downregulation. These two transcription factors activate expression profiles involved in migration, invasion and vascularisation [181]. Therefore, in trophoblast, miR-210 expression correlates with a negative regulation of migration and invasion, mediated by downregulation of EFNA3 and HOXA9, in response to hypoxia, ROS and activated NFK-B signaling.

Further studies have identified additional downstream targets of miR-210 in preeclampsia, which are downregulated in preeclamptic samples and whose expression is altered upon miR-210 activation in cell models. A few examples are inflammation related molecules STAT6 and IL-4 [271], potassium channel modulatory factor 1 (KCMF1) [272], thrombospondin type I domain containing 7A (THSD7A) [273].

This mounting body of evidence highlights a key role of miR-210 in the development and maintainance of a preeclamptic phenotype. However it is still not clear which is the triggering event. It is possible that complications during implantation trigger an immune response which would create a pro-inflammatory environment, activating NFK-B signaling, causing aberrant expression of miR-210 and all consequent downstream cascades. Recently, Chen and collaborator (2019) analysed the inflammatory profile of preeclamptic women, compared to patients which experienced healthy pregnancie [274]. The concentrations of proinflammatory cytokines (IL-6, IL-17) were higher in plasma samples from peripheral blood in the preeclampsia group. Moreover, Transforming Growth Factor $\beta 1$ (TGF $\beta 1$ ) levels were higher as well. TGF $\beta 1$ has the function of promoting the prevalence of a subset of regulatory $\mathrm{T}$ cells (Tregs) that maintain immunotolerance, allowing a successful implantation and avoiding an immune response against the foetal tissues. These Tregs are characterised by expression of the fork-head box $\mathrm{p} 3$ (Foxp3) transcription factor, which promotes an immunotolerant phenotype [275]. However, proinflammatory signals such as IL-6 cause the activation of T cells at the expense of Foxp3-positive Tregs, causing an activation of inflammatory responses. Zhao and coworkers showed that miR210 was upregulated in preeclamptic placentas and Foxp3 mRNA and protein levels were found downregulated, previous studies had shown evidence of direct regulation of Fox3p by miR210, 
suggesting a pivotal role of this microRNA in regulating the threshold of immunotolerance by altering the balance of Foxp3+ Tregs/activated Tcells [276].

miR-155

miR-155 is upregulated in preeclamptic placentas [255]. This upregulation correlates inversely with the level of cysteine-rich protein 61(CYR61) [277], which is a factor secreted by different cell types, including trophoblast, involved in promoting migration, invasion, angiogenesis and vascularisation $[278,279]$. miR-155 directly targets the $3^{\prime}$-UTR of CYR61 mRNA with a perfect match, causing transcriptional and translational repression. In vitro experiments (HTR-8/SVneo trophoblast cell line) showed how miR-155 inhibits CYR61-mediated expression of VEGF, inhibiting trophoblast migration [277]. Decreased trophoblast-mediated secretion of VEGF would negatively affect angiogenesis and vascularisation in the site of placenta development.

miR-155 regulates trophoblast proliferation and migration also by directly targeting the cell cycle gene Cyclin D1 [172]. Cyclin D1 is involved in cell cycle progression, migration and invasion of trophoblast lineages, downregulated in preeclamptic placentas at both mRNA and protein levels [280-282]. In vitro studies have shown how miR-155 through direct targeting of the $3^{\prime}$ UTR of CyclinD mRNA downregulates mRNA and protein levels, negatively affecting migration, causing cell cycle arrest and decrease in proliferation in HTR-8/SVneo cells [42]. Exiting cell cycle is a step of terminal differentiation, which suggests how miR-155 overexpression, as found in preeclampsia, could lead to a premature differentiation of cytotrophoblasts, possibly inducing syncytialization. This phenomenon would cause depletion of the cytotrophoblast pool, accelerating placental aging.

In sum, miR-155 modulates proliferation, migration and invasion of trophoblasts and its expression can affect the phenotype of endothelial cells by negatively regulating VEGF release. miR-155 deregulation could have catastrophic consequences in placentation, deeply affecting trophoblast infiltration, vascularization and angiogenesis of the developing placenta.

Circulating miR-155

Maternal plasma from preeclamptic women presented significantly statistically higher levels of miR-155 [283]. In blood, microRNAs are quite stable and can travel through circulation, to be uptaken by different cell types, such as endothelial and immune cells, regulating gene expression [284]. Yang, Zhang and Ding (2017) showed how plasma levels of miR-155 positively correlate with proinflammatory cytokine interleukin-17 (IL-17) and with proteinuria and urine podocytes counts in women with preeclampsia. Similarly to miR-210, miR-155 promoter presents a binding site for NFk-B and can be activated by this inflammation master regulator, which could suggest a similar pattern of regulation for miR-155 and pro-inflammatory factors, other than a direct interaction between these genes [285].

miR-155 in Endothelial Cells

Endothelial cells play a fundamental role in placentation given the copious vascularisation and angiogenesis that takes place in the maternal endometrium during placentation. In preeclampsia, pro-inflammatory factors and secreted molecules from the preeclamptic placenta produce an excessive activation of the maternal endothelium, resulting in endothelyal dysfunction, culminating in inflammation, blood pressure changes, downstream systemic effects [286]. miR-155 has been found to be downregulated in human umbelical vein endothelial cells (HUVECs) from preeclamptic women, compared to HUVECs from healthy pregnant women [287]. This downregulation correlated with an increase in Angiotensin II Receptor 1 (AT1R) and increased phosphorylation of Extracellular Signal-regulated Kinases1/2 (ERKs), identifying AT1R as direct target of miR-155 [287]. Activation of the Angiotensin II- AT1R through ERK1/2 in endothelial cells causes cell cycle arrest and initiation of senescence pathways; miR-155 depletion-dependent increase in AT1R will render endothelial cells more sensitive to blood level of Angiotensin II, promoting endothelial damage [288]. 
miR-155 has been implicated in regulating Nitric Oxide (NO) production in endothelial cells. $\mathrm{NO}$ is a potent vasodilator and reduced levels of NO have been associated with preeclampsia etiology [289,290]. In vitro studies using HUVECs proved how endothelial Nitric Oxide synthase (eNOS) mRNA is a direct target of miR-155; proinflammatory stimuli upregulate miR-155 expression in these cells in vitro, downregulating eNOS and NO production [290]. As mentioned above, microRNAs can be found in plasma and miR-155 is upregulated in plasma of women with preeclampsia [69]. microRNAs can be free in circulation or travel inside vescicles and exosomes, which can be uptaken by target cells, activating signaling pathways, affecting expression profiles [291]. Shen and collaborators (2018) elegantly showed how exosomes from plasma samples of preeclamptic patients can affect eNOS mRNA and protein levels in HUVECs [292]. In particular, treatment of HUVECs in vitro with isolated exosomes from plasma of preeclamptic patients (compared to exosomes from control group) caused a statistically significant decrease in eNOS mRNA and protein levels, which correlated with decreased NO production. When analysing the composition of the exosomes, miR-155 was found to be upregulated in the preeclamptic group. Follow up in vitro tests proved how miR-155 located in the exosomes affects eNOS regulation in endothelial cells.

\section{miR-155 in Vascular Smooth Muscle Cells}

In arteries and arterioles, endothelial cells are interspaced by vascular smooth muscle cells (VSMCs) which thanks to their contractile properties allow vasoconstriction and vasodilation to occur, accomodating for changes in blood pressure. VSMCs generally present a contractile phenotype characterised by elongated spindle-like morphology, high concentration of contractile filaments. In response to external stimuli, they can switch to a synthetic phenotype characterised by loss of contractility markers, rhomboid morphology, increased proliferative and migratory potential; in this state VSMCs cells lose the ability to modulate vascular resistance [293]. Phenotypic regulation of VSMCs is driven by soluble guanylate cyclase (sGC) which increases intracellular levels of guanosine monophosphate (cGMP), key messenger molecule. cGMP is the substrate of cyclic GMP-dependent protein kinase (PKG) which activates downstream signaling pathways promoting VSMCs contractile phenotype. Nitric Oxide produced by endothelial cells positively modulates sGC activity, favouring vasodilation through enhancement of the VSMCs contractile phenotype [294,295].

In the presence of proinflammatory cytokine Transforming Necrosis Factor $\alpha(\mathrm{TNF} \alpha)$, miR-155 was found to be directly activated by NFK-B in in vitro model of VSMCs. The upregulated miR-155 directly interacts with the $3^{\prime}$-UTR of the mRNA of PKG1 [296] and of the $\beta 1$ subunit of guanylate cyclase (sGC $\beta 1$ ), resulting in translational repression and mRNA degradation [297]. As a consequence of sGC $\beta 1$ downregulation, intracellular cGMP levels are strongly decreased and the downregulation of PKG1 inhibits downstream pathways [296,297]. Park and collaborators (2019) co-cultured HUVECs and VSMCs, observing higher cGMP accumulation in VSMCs, which is mediated by Ntric Oxide stimulation, produced by the endothelial cells [297]. This could be countered by ectopic miR-155 expression in VSMCs. miR-155 overexpressing in response to TNF $\alpha$, mediating inhibition of the sGC/PKG pathway, causes downregulation of contractile protein markers. This results in a shift of VSMCs to a synthetic phenotype, assuming a rhomboid morphology, increasing proliferation and migration rates. Interestingly the pro-contractile effects of Nitric Oxide could be cancelled by miR-155 expression [296,297]. In placental vessels of preeclamptic placenta sGC $\beta 1$ mRNA levels are downregulated [297], given the evidence provided on miR-155 repression of the sGC/PKG pathway, we can imagine that PKG1 might be downregulated as well. In response to inflammation, both endothelial and smooth muscle cells are affected and in preeclampsia they overexpress miR-155 which alters their ability to produce and respond to vasodilation stimuli. Taken together, this evidence highlights the pivotal role of inflammation and miR-155 in the etiology of the preeclamptic phenotype. 
Potential Biomarkers: microRNAs Circulating in Maternal Plasma

Since the identification of circulating small RNAs in plasma samples, the prospect of their potential use as diagnostic and predictive biomarkers has fueled extensive research [298]. In the context of preeclampsia, the finding that small microRNAs with placental origin can travel in the blood circulation and affect systemically different cell types opens new avenues for the understanding of the mechanisms of this complex disease [299,300].

In Table 4 are listed some of the microRNAs that have been found deregulated in plasma samples of preeclamptic patients. In several studies, groups of microRNAs differentially expressed have been analyzed for their potential as predictive biomarkers of the preeclamptic phenotype [301-305]. These studies show how blood levels elevation of PE-associated microRNAs can be predictive for the preeclamptic phenotype starting from the second trimester. Li and collaborators (2015) evaluated the predictive values of the upregulated micro-RNAs miR-152, miR-183 and miR-210 by plotting the corresponding receiver operating characteristic curves. In the second trimester samples, the Area Under the Curve (AUC) indicated strong predictive values and were respectively 0.93 for miR-210, 0.97 for miR-183 and 0.94 for miR-152. Interestingly, different studies investigated the predictive power of miR-210 and, even though all results highlighted its key role in preeclampsia and potential as diagnostic marker, the AUCs varied in a range between 0.7 and 0.94 [301-303,305]. This variation might be due to differences in patient cohorts, samples collections and handling; however, the fact that miR-210 still emerged as predictive biomarker is encouraging.

Winger and collaborators (2018) collected peripheral blood cells in preeclamptic and control patient group, analysing the expression levels of a subset of 30 microRNAs previously identified altered in preeclampsia. 48 samples were divided in a training and a validation group. Analysis of differentially expressed microRNAs in the training cohort identified a panel of 8 microRNAs with good prediction values (AUC > 0.75) and $p$ value $\leq 0.05$ : miR-1267, miR-148a, miR-196a, miR-33a, miR-575, miR-582, miR-210, miR-16. The panel was successfully validated and the use of the 8 microRNAs combined increased the prediction power of the tests [305].

From Table 4, it is possible to appreciate the heterogeneity of findings across different studies. These discrepancies in the repertoires of circulating miRNAs complicate the identification of useful biomarkers. This heterogeneity could partly be explained by the fact that preeclampsia is a complex systemic disease that develops over months of gestation; therefore, the panel of circulating molecules in blood samples might vary considerably depending of the time point at which samples are collected. Another possible explanation might reside in the wide range of different methodologies used for the extraction of circulating RNAs which introduce technical variability [306,307]. Moreover, there is mounting evidence on how the current techniques are able to detect only a small fraction of the total bulk of circulating RNAs (WO2009093254A2). Therefore, further research is still required to improve our technical knowledge so to design better, more consistent methodologies for the identification of circulating biomarkers, that might one day allow the design of diagnostic panels for effective early detection and prevention of preeclampsia.

\subsubsection{Additional Considerations on the Analysis of lncRNA Functions}

Possible Caveats of the Current Trophoblast In Vitro Models

Many of the lncRNAs found to be deregulated in preeclamptic placenta have previously been identified in cancers, where they have a role in regulating proliferation, migration, invasion and apoptosis. Most of these PE-associated lncRNAs have pro-survival and pro-migration properties, therefore downregulation is associated with activation of apoptosis, decreased migratory potential and proliferative rate.

Once they have been found to be downregulated in preeclamptic placenta, the main objective has been to investigate the molecular function of these lncRNAs in the context of placenta physiology and preeclampsia. In vitro studies have seen the use of classical cellular models of trophoblast, either 
choriocarcinoma cell lines (JEG3 and BeWo) or artificially immortalized cell lines (HTR-8/SVneo). Through these in vitro studies it has been established that most of these lncRNAs regulate proliferation, invasion and migration of the trophoblast.

Table 4. Deregulated miRNA in preeclampsia.

\begin{tabular}{|c|c|c|c|c|c|c|}
\hline microRNA & $\begin{array}{c}\text { PE } \\
\text { Placenta }\end{array}$ & $\begin{array}{c}\text { PE } \\
\text { Plasma }\end{array}$ & Function & Gene targets & AUC & References \\
\hline miR-214 & DOWN & & & & & [308] \\
\hline miR-152 & & DOWN & & & & [300] \\
\hline miR-590 & DOWN & & & & & [308] \\
\hline miR-18a & DOWN & DOWN & Promoting trophoblast migration & SMAD2 & & {$[225,308]$} \\
\hline miR-19a & DOWN & & & & & [308] \\
\hline miR-411 & DOWN & & & & & [308] \\
\hline miR-195 & DOWN & & & & & [308] \\
\hline $\mathrm{miR}-223$ & DOWN & & & & & [308] \\
\hline $\operatorname{miR}-363$ & DOWN & & & & & [308] \\
\hline miR-542-3p & DOWN & & & & & [308] \\
\hline $\operatorname{miR}-30 a-3 p$ & UP & & & & & [308] \\
\hline miR-151 & UP & & & & & [308] \\
\hline miR-31 & UP & & & & & [308] \\
\hline $\operatorname{miR}-210$ & UP & UP & & PTPN2 & $0.7<\mathrm{AUC}<0.9$ & $\begin{array}{l}{[225,255,300,302,} \\
303,305,308,309]\end{array}$ \\
\hline $\operatorname{miR}-17-3 p$ & UP & & & & & [308] \\
\hline miR-193b & UP & & & & & [308] \\
\hline $\operatorname{miR}-638$ & UP & & & & & [308] \\
\hline miR-525 & UP & & & & & [308] \\
\hline miR-515-3p & UP & & & & & [308] \\
\hline miR-519e & UP & & & & & [308] \\
\hline miR-517-5p & UP & UP & & & $\mathrm{AUC}=0.7$ & [304] \\
\hline miR-1267 & & UP & & & AUC $>0.8$ & [305] \\
\hline miR-148a & & UP & Immune response & HLA-G & AUC $>0.9$ & {$[305,310]$} \\
\hline miR-196a & & UP & & & $\mathrm{AUC}=1$ & [305] \\
\hline miR-33a & & UP & & & $\mathrm{AUC}=1$ & [305] \\
\hline $\operatorname{miR}-575$ & & UP & & & AUC $>0.9$ & [305] \\
\hline miR-582 & & UP & Trophoblast invasion, migration & VEGF & 1 & {$[305,311]$} \\
\hline miR-152 & UP & UP & Immune response & HLA-G & AUC $>0.9$ & {$[256,301,312]$} \\
\hline miR-183 & UP & UP & Cell differentiation, apoptosis, invasion & & AUC $>0.9$ & {$[255,301,313]$} \\
\hline $\operatorname{miR}-215$ & & UP & & & & [225] \\
\hline miR-650 & & UP & & & & [225] \\
\hline miR-21 & UP & UP & Apoptosis & & & {$[225,314]$} \\
\hline $\operatorname{miR}-29 a$ & & UP & & & & [225] \\
\hline miR-300 & & UP & Trophoblast differentiation & ETS-1 & & [315] \\
\hline
\end{tabular}

Annotations: AUC = Area Under the Curve; SMAD2 = Mothers Against Decapentaplegic Homolog 2; PTPN2 = Tyrosine-protein phosphatase non-receptor type 2; HLA-G = Histocompatibility antigen, alpha chain G; VEGF = Vascular endothelial growth factor; ETS-1 = E26 oncogene homolog 1 ; TGF $\beta=$ Tumor growth factor $\beta$.

Have we completely unfolded the role of PE-associated lncRNA in the human placenta? Since IncRNAs have been previously identified in cancers, it is possible that the functions we have attributed them in the placenta are actually a result of the fact that we are analyzing them in cell lines that are cancer-like. Therefore, there is still the possibility that these lncRNAs have additional distinct functions in placenta that could be highlighted using more physiological placenta models. The recent development of placenta organoids from stem cells rises the hope for exciting new avenues, to explore these questions [316]. 
What about the Syncytiotrophoblast?

Migration, apoptosis, invasiveness and proliferation are functions shared between cancer cells and by cytotrophoblast (CTB) especially by the extravillous trophoblast (EVT) in the placenta, the in vitro investigations into PE associated lncRNAs have so far focused on EVT cell line models (e.g., JEG3, HTR-8/SVneo). However, it is important to highlight how transcriptomic data from placenta samples are a result of overall placenta gene expression levels. The extracted placental RNA comes from all the different cell types present in the tissue and the most abundant cell populations are represented by cytotrophoblasts and syncytiotrophoblasts (SCT). Even though it is true that CTB and EVT cells are fundamental for implantation and correct placental development, the syncytiotrophoblast is the functional core of the placenta itself, constituting the barrier for nutrient exchanges between fetal and maternal vasculatures and acting as secretory organ that hormonally regulates progression of gestation. Liu and coworkers (2017), in their work on RNA-ATB, showed a strong in situ hybridization staining of lncRNA-ATB in the syncytiotrophoblast layer of the placenta, reinforcing the idea that the syncytiotrophoblast might be equally affected by deregulation in the lncRNAs species [248]. Yu and coworkers (2018) work on MEG3 showed how MEG3 downregulation observed in preeclampsia correlates with an increase in adhesion molecule E-cadherin [224]. While it is true that this molecule is important for endothelial-mesenchymal transition, and its alteration would affect trophoblast invasion and EVT migration, E-cadherin downregulation after cytotrophoblast cell-cell interaction has been implicated in CTB syncytialization [317]. Suggesting that MEG3 might affect STB physiology as well.

Therefore, there are still potentially interesting questions to be raised: what are the effects of downregulated lncRNAs on the physiology of the CTB and SCT? Do we see an alteration of the proliferative state of the $\mathrm{CTB}$, does this cause premature placental aging? Does this deregulation affect the differentiation potential of the CTB, affecting the balance between CTB renewal and SCT terminal differentiation? Do these lncRNAs have other functions, exclusive to placenta, other than the ones shared with cancer?

\subsection{Histone Modifications}

Few studies addressed the question of histone code modifications in PE. Chakraborty and coll. evidenced a HIF-KDM3A-MMP12 signaling cascade that promotes trophoblast invasion and trophoblast-directed uterine spiral artery remodeling in rat placenta and human placental cells. Hypoxia drives HIF activation and KDM3A expression, which in return will alter the histone methylation status of genes promoting development of the invasive trophoblast lineage and tissue remodeling, illustrated with trophoblast-derived MMP12 activation [318]. Hypoxia was also shown to affect the histone demethylase JMJD6 (Jumonji domain containing protein 6) and JMJD6 demethylase activity was shown to be drastically reduced in PE placenta as compared to Control Placenta [319]. Very recently, the expressions of HDACs were investigated in PE placentas and only HDAC9 was found downregulated both at the mRNA and protein levels in syncytiotrophoblast cells. Knock-down of HDAC9 in HTR-8/SVneo cells inhibits trophoblast cell migration and invasion. TIMP3, an inhibitory of MMP involved in invasion and tissue remodeling, is a direct target of HDAC9, identified by ChIP and is upregulated in the absence of HDAC9 [320].

\subsection{Imprinting}

Overall, preeclampsia cannot be considered an imprinting disease, despite the fact that a recent study showed that imprinted genes are more differentially expressed in PE than other genes, with paternally expressed genes (inducing placental growth) rather down-regulated and maternally expressed genes upregulated [151]. A systematic analysis of preeclampsia placental gene expression and imprinted genes was carried out in 2017 [321], which revealed altered expression of DLX5 in human PE placentas but with a rather mild deregulation ( 2 fold). To be mentioned as well, the first gene identified by positional cloning in preeclampsia, STOX1, is imprinted in specific placental cell 
subtypes [322,323]. The mutation originally found in STOX1 has rather a gain-of-function effect [323] and in fact, overexpression of STOX1 induces a preeclamptic expression profile and a preeclamptic phenotype in cells or in mice, respectively [7,324]. To note, however, we have no evidence that Stox 1 is imprinted in mice, therefore it is suspected that the mere ectopic and untimely overexpression of this factor is the cause of the disease. The idea that an imprinted gene is implicated in preeclampsia has been cleverly substantiated by Jennifer Graves as early as 1998 [325] and she gave theoretical reasons why this should be the case. The future will tell us if more examples of imprinted preeclampsia-associated genes exist in the human genome.

\section{Perspectives and Conclusions}

The recent years have seen the emergence of an increasing number of studies focused on the role of epigenetics in the regulation of placental development and on its potential implication in placental pathologies. However, we still lack a precise picture on how these epigenetic modifications correlate with gene expression. In particular, we have a limited knowledge on how DNA-methylation or Histone modifications impact gene expression in normal and pathological placenta development. In addition, our knowledge on the mechanisms regulating the dynamics of the instauration of the different epigenetic marks across development is very scarce. Nevertheless, recent studies have started to reveal how epigenetics is involved in the regulation of important processes in placental development such as cell fate determination, syncytialization or EVT migration and invasion. The emergence of new technologies allowing the study of the epigenetic and transcriptomic profiles of the different cells types of the placenta will certainly greatly contribute to improve our understanding of epigenetics in placenta. Moreover, in the context of PE, to date, the studies analyzing epigenetic modifications have focused on the placenta, however the antiangiogenic and cytotoxic factors released by the PE placenta have the potential to induce epigenetics modifications in maternal target tissues (blood cells, endothelial cells). This could impact the future maternal and fetal health and deserves to be studied in detail. Overall, the comprehension of epigenetic regulation in preeclampsia both at the level of the placenta and other involved organs could provide new biomarkers and therapeutic targets to improve the management of this disease. For the moment, this has not been successfully applied as diagnostic or prognostic of preeclampsia. One explanation of this observation could be that the extraction of circulating RNAs from the plasma is still immature technologically, leading to discrepant results between various laboratories and absence of consensus in defining a panel of diagnostic miRNA. This may evolve in the future, leading to substantial exploitation of these markers in complex diseases, including preeclampsia.

Supplementary Materials: Supplementary materials can be found at http://www.mdpi.com/1422-0067/20/11/ 2837/s1. Table S1. High-throughput studies analyzing methylation profiles of different relevant tissues in the context of preeclampsia $[42,43,47,54-73]$.

Funding: F.M., C.M. and D.V. are funded by INSERM, C.S.M.R. and C.A. are PhD students, funded by the H2020 European project 'iPLACENTA,' headed by Colin Murdoch.

Conflicts of Interest: The authors declare no conflict of interest. The funders had no role in the design of the study; in the collection, analyses, or interpretation of data; in the writing of the manuscript, or in the decision to publish the results.

\section{References}

1. Steegers, E.A.; von Dadelszen, P.; Duvekot, J.J.; Pijnenborg, R. Pre-eclampsia. Lancet 2010, 376, 631-644. [CrossRef]

2. Roland, C.S.; Hu, J.; Ren, C.E.; Chen, H.; Li, J.; Varvoutis, M.S.; Leaphart, L.W.; Byck, D.B.; Zhu, X.; Jiang, S.W. Morphological changes of placental syncytium and their implications for the pathogenesis of preeclampsia. Cell. Mol. Life Sci. 2016, 73, 365-376. [CrossRef] [PubMed]

3. Redman, C.W.; Sargent, I.L. Latest advances in understanding preeclampsia. Science 2005, 308, $1592-1594$. [CrossRef] [PubMed] 
4. Fisher, S.J. Why is placentation abnormal in preeclampsia? Am. J. Obstet. Gynecol. 2015, 213, S115-S122. [CrossRef] [PubMed]

5. Huppertz, B. Placental origins of preeclampsia: Challenging the current hypothesis. Hypertension 2008, 51, 970-975. [CrossRef] [PubMed]

6. Huppertz, B. The Critical Role of Abnormal Trophoblast Development in the Etiology of Preeclampsia. Curr. Pharm. Biotechnol. 2018, 19, 771-780. [CrossRef] [PubMed]

7. Doridot, L.; Passet, B.; Mehats, C.; Rigourd, V.; Barbaux, S.; Ducat, A.; Mondon, F.; Vilotte, M.; Castille, J.; Breuiller-Fouche, M.; et al. Preeclampsia-like symptoms induced in mice by fetoplacental expression of STOX1 are reversed by aspirin treatment. Hypertension 2013, 61, 662-668. [CrossRef] [PubMed]

8. Sibley, C.P.; Pardi, G.; Cetin, I.; Todros, T.; Piccoli, E.; Kaufmann, P.; Huppertz, B.; Bulfamante, G.; Cribiu, F.M.; Ayuk, P.; et al. Pathogenesis of intrauterine growth restriction (IUGR)-conclusions derived from a European Union Biomed 2 Concerted Action project 'Importance of Oxygen Supply in Intrauterine Growth Restricted Pregnancies'-a workshop report. Placenta 2002, 23 (Suppl. A), S75-S79. [CrossRef]

9. Possomato-Vieira, J.S.; Khalil, R.A. Mechanisms of Endothelial Dysfunction in Hypertensive Pregnancy and Preeclampsia. Adv. Pharmacol. 2016, 77, 361-431.

10. Nelissen, E.C.; van Montfoort, A.P.; Dumoulin, J.C.; Evers, J.L. Epigenetics and the placenta. Hum. Reprod. Update 2011, 17, 397-417. [CrossRef]

11. Vaiman, D. Genes, epigenetics and miRNA regulation in the placenta. Placenta 2017, 52, 127-133. [CrossRef] [PubMed]

12. Robinson, W.P.; Price, E.M. The human placental methylome. Cold Spring Harb. Perspect. Med. 2015, 5, a023044. [CrossRef] [PubMed]

13. Januar, V.; Desoye, G.; Novakovic, B.; Cvitic, S.; Saffery, R. Epigenetic regulation of human placental function and pregnancy outcome: Considerations for causal inference. Am. J. Obstet. Gynecol. 2015, 213, S182-S196. [CrossRef] [PubMed]

14. Fu, G.; Brkic, J.; Hayder, H.; Peng, C. MicroRNAs in Human Placental Development and Pregnancy Complications. Int. J. Mol. Sci. 2013, 14, 5519-5544. [CrossRef] [PubMed]

15. Burton, G.J.; Fowden, A.L. The placenta: A multifaceted, transient organ. Philos. Trans. R. Soc. Lond. B Biol. Sci. 2015, 370, 20140066. [CrossRef]

16. James, J.L.; Carter, A.M.; Chamley, L.W. Human placentation from nidation to 5 weeks of gestation. Part I: What do we know about formative placental development following implantation? Placenta 2012, 33, 327-334. [CrossRef]

17. Knofler, M. Critical growth factors and signalling pathways controlling human trophoblast invasion. Int. J. Dev. Biol. 2010, 54, 269-280. [CrossRef]

18. Knofler, M.; Pollheimer, J. Human placental trophoblast invasion and differentiation: A particular focus on Wnt signaling. Front. Genet. 2013, 4, 190. [CrossRef]

19. Rouault, C.; Clement, K.; Guesnon, M.; Henegar, C.; Charles, M.-A.; Heude, B.; Evain-Brion, D.; Degrelle, S.A.; Fournier, T. Transcriptomic signatures of villous cytotrophoblast and syncytiotrophoblast in term human placenta. Placenta 2016, 44, 83-90. [CrossRef]

20. Khan, M.A.; Manna, S.; Malhotra, N.; Sengupta, J.; Ghosh, D. Expressional regulation of genes linked to immunity \& programmed development in human early placental villi. Indian J. Med. Res. 2014, 139, 125-140.

21. Henikoff, S.; Greally, J.M. Epigenetics, cellular memory and gene regulation. Curr. Biol. 2016, 26, R644-R648. [CrossRef] [PubMed]

22. Zhang, G.; Pradhan, S. Mammalian epigenetic mechanisms. IUBMB Life 2014, 66, 240-256. [CrossRef] [PubMed]

23. Rahat, B.; Sharma, R.; Bagga, R.; Hamid, A.; Kaur, J. Imbalance between matrix metalloproteinases and their tissue inhibitors in preeclampsia and gestational trophoblastic diseases. Reproduction 2016, 152, 11-22. [CrossRef] [PubMed]

24. Dokras, A.; Gardner, L.M.; Kirschmann, D.A.; Seftor, E.A.; Hendrix, M.J. The tumour suppressor gene maspin is differentially regulated in cytotrophoblasts during human placental development. Placenta 2002, 23, 274-280. [CrossRef] [PubMed]

25. Dokras, A.; Coffin, J.; Field, L.; Frakes, A.; Lee, H.; Madan, A.; Nelson, T.; Ryu, G.Y.; Yoon, J.G.; Madan, A. Epigenetic regulation of maspin expression in the human placenta. Mol. Hum. Reprod. 2006, 12, 611-617. [CrossRef] [PubMed] 
26. Camolotto, S.A.; Racca, A.C.; Ridano, M.E.; Genti-Raimondi, S.; Panzetta-Dutari, G.M. PSG gene expression is up-regulated by lysine acetylation involving histone and nonhistone proteins. PLoS ONE 2013, 8, e55992. [CrossRef] [PubMed]

27. Chuang, H.C.; Chang, C.W.; Chang, G.D.; Yao, T.P.; Chen, H. Histone deacetylase 3 binds to and regulates the GCMa transcription factor. Nucleic Acids Res. 2006, 34, 1459-1469. [CrossRef] [PubMed]

28. Abell, A.N.; Jordan, N.V.; Huang, W.; Prat, A.; Midland, A.A.; Johnson, N.L.; Granger, D.A.; Mieczkowski, P.A.; Perou, C.M.; Gomez, S.M.; et al. MAP3K4/CBP-regulated H2B acetylation controls epithelial-mesenchymal transition in trophoblast stem cells. Cell Stem Cell 2011, 8, 525-537. [CrossRef]

29. Ellery, P.M.; Cindrova-Davies, T.; Jauniaux, E.; Ferguson-Smith, A.C.; Burton, G.J. Evidence for transcriptional activity in the syncytiotrophoblast of the human placenta. Placenta 2009, 30, 329-334. [CrossRef]

30. Fogarty, N.M.; Burton, G.J.; Ferguson-Smith, A.C. Different epigenetic states define syncytiotrophoblast and cytotrophoblast nuclei in the trophoblast of the human placenta. Placenta 2015, 36, 796-802. [CrossRef]

31. Xu, Y.; Ge, Z.; Zhang, E.; Zuo, Q.; Huang, S.; Yang, N.; Wu, D.; Zhang, Y.; Chen, Y.; Xu, H.; et al. The lncRNA TUG1 modulates proliferation in trophoblast cells via epigenetic suppression of RND3. Cell Death Dis. 2017, 8, e3104. [CrossRef] [PubMed]

32. Song, X.; Rui, C.; Meng, L.; Zhang, R.; Shen, R.; Ding, H.; Li, J.; Li, J.; Long, W. Long non-coding RNA RPAIN regulates the invasion and apoptosis of trophoblast cell lines via complement protein C1q. Oncotarget 2017, 8,7637-7646. [CrossRef] [PubMed]

33. Chen, H.; Meng, T.; Liu, X.; Sun, M.; Tong, C.; Liu, J.; Wang, H.; Du, J. Long non-coding RNA MALAT-1 is downregulated in preeclampsia and regulates proliferation, apoptosis, migration and invasion of JEG-3 trophoblast cells. Int. J. Clin. Exp. Pathol. 2015, 8, 12718-12727. [PubMed]

34. Zhang, Y.; Zou, Y.; Wang, W.; Zuo, Q.; Jiang, Z.; Sun, M.; De, W.; Sun, L. Down-regulated long non-coding RNA MEG3 and its effect on promoting apoptosis and suppressing migration of trophoblast cells. J. Cell. Biochem. 2015, 116, 542-550. [CrossRef] [PubMed]

35. Muys, B.R.; Lorenzi, J.C.; Zanette, D.L.; Lima e Bueno Rde, B.; de Araujo, L.F.; Dinarte-Santos, A.R.; Alves, C.P.; Ramao, A.; de Molfetta, G.A.; Vidal, D.O.; et al. Placenta-Enriched LincRNAs MIR503HG and LINC00629 Decrease Migration and Invasion Potential of JEG-3 Cell Line. PLoS ONE 2016, 11, e0151560. [CrossRef] [PubMed]

36. Zou, Y.; Jiang, Z.; Yu, X.; Sun, M.; Zhang, Y.; Zuo, Q.; Zhou, J.; Yang, N.; Han, P.; Ge, Z.; et al. Upregulation of long noncoding RNA SPRY4-IT1 modulates proliferation, migration, apoptosis, and network formation in trophoblast cells HTR-8SV/neo. PLoS ONE 2013, 8, e79598. [CrossRef] [PubMed]

37. Zuo, Q.; Huang, S.; Zou, Y.; Xu, Y.; Jiang, Z.; Zou, S.; Xu, H.; Sun, L. The Lnc RNA SPRY4-IT1 Modulates Trophoblast Cell Invasion and Migration by Affecting the Epithelial-Mesenchymal Transition. Sci. Rep. 2016, 6, 37183. [CrossRef] [PubMed]

38. Yu, L.L.; Chang, K.; Lu, L.S.; Zhao, D.; Han, J.; Zheng, Y.R.; Yan, Y.H.; Yi, P.; Guo, J.X.; Zhou, Y.G.; et al. Lentivirus-mediated RNA interference targeting the $\mathrm{H} 19$ gene inhibits cell proliferation and apoptosis in human choriocarcinoma cell line JAR. BMC Cell Biol. 2013, 14, 26. [CrossRef] [PubMed]

39. Saha, S.; Chakraborty, S.; Bhattacharya, A.; Biswas, A.; Ain, R. MicroRNA regulation of Transthyretin in trophoblast differentiation and Intra-Uterine Growth Restriction. Sci. Rep. 2017, 7, 16548. [CrossRef]

40. Umemura, K.; Ishioka, S.; Endo, T.; Ezaka, Y.; Takahashi, M.; Saito, T. Roles of microRNA-34a in the pathogenesis of placenta accreta. J. Obstet. Gynaecol. Res. 2013, 39, 67-74. [CrossRef]

41. Doridot, L.; Houry, D.; Gaillard, H.; Chelbi, S.T.; Barbaux, S.; Vaiman, D. miR-34a expression, epigenetic regulation, and function in human placental diseases. Epigenetics 2014, 9, 142-151. [CrossRef] [PubMed]

42. Dai, Y.; Qiu, Z.; Diao, Z.; Shen, L.; Xue, P.; Sun, H.; Hu, Y. MicroRNA-155 inhibits proliferation and migration of human extravillous trophoblast derived HTR-8/SVneo cells via down-regulating cyclin D1. Placenta 2012, 33, 824-829. [CrossRef]

43. Kumar, P.; Luo, Y.; Tudela, C.; Alexander, J.M.; Mendelson, C.R. The c-Myc-regulated microRNA-17 92 (miR-17 92) and miR-106a 363 clusters target hCYP19A1 and hGCM1 to inhibit human trophoblast differentiation. Mol. Cell. Biol. 2013, 33, 1782-1796. [CrossRef] [PubMed]

44. Gao, W.L.; Liu, M.; Yang, Y.; Yang, H.; Liao, Q.; Bai, Y.; Li, Y.X.; Li, D.; Peng, C.; Wang, Y.L. The imprinted H19 gene regulates human placental trophoblast cell proliferation via encoding miR-675 that targets Nodal Modulator 1 (NOMO1). RNA Biol. 2012, 9, 1002-1010. [CrossRef] [PubMed] 
45. Xie, L.; Mouillet, J.F.; Chu, T.; Parks, W.T.; Sadovsky, E.; Knofler, M.; Sadovsky, Y. C19MC microRNAs regulate the migration of human trophoblasts. Endocrinology 2014, 155, 4975-4985. [CrossRef] [PubMed]

46. Novakovic, B.; Fournier, T.; Harris, L.K.; James, J.; Roberts, C.T.; Yong, H.E.J.; Kalionis, B.; Evain-Brion, D.; Ebeling, P.R.; Wallace, E.M.; et al. Increased methylation and decreased expression of homeobox genes TLX1, HOXA10 and DLX5 in human placenta are associated with trophoblast differentiation. Sci. Rep. 2017, 7, 4523. [CrossRef] [PubMed]

47. Wong, N.C.; Novakovic, B.; Weinrich, B.; Dewi, C.; Andronikos, R.; Sibson, M.; Macrae, F.; Morley, R.; Pertile, M.D.; Craig, J.M.; et al. Methylation of the adenomatous polyposis coli (APC) gene in human placenta and hypermethylation in choriocarcinoma cells. Cancer Lett. 2008, 268, 56-62. [CrossRef] [PubMed]

48. Shi, X.; Liu, H.; Cao, J.; Liu, Q.; Tang, G.; Liu, W.; Liu, H.; Deng, D.; Qiao, F.; Wu, Y. Promoter Hypomethylation of Maspin Inhibits Migration and Invasion of Extravillous Trophoblast Cells during Placentation. PLoS ONE 2015, 10, e0135359. [CrossRef] [PubMed]

49. Chiu, R.W.; Chim, S.S.; Wong, I.H.; Wong, C.S.; Lee, W.S.; To, K.F.; Tong, J.H.; Yuen, R.K.; Shum, A.S.; Chan, J.K.; et al. Hypermethylation of RASSF1A in human and rhesus placentas. Am. J. Pathol. 2007, 170, 941-950. [CrossRef] [PubMed]

50. Lister, R.; Pelizzola, M.; Kida, Y.S.; Hawkins, R.D.; Nery, J.R.; Hon, G.; Antosiewicz-Bourget, J.; O’Malley, R.; Castanon, R.; Klugman, S.; et al. Hotspots of aberrant epigenomic reprogramming in human induced pluripotent stem cells. Nature 2011, 471, 68-73. [CrossRef] [PubMed]

51. Schroeder, D.I.; Blair, J.D.; Lott, P.; Yu, H.O.; Hong, D.; Crary, F.; Ashwood, P.; Walker, C.; Korf, I.; Robinson, W.P.; et al. The human placenta methylome. Proc. Natl. Acad. Sci. USA 2013, 110, 6037-6042. [CrossRef] [PubMed]

52. Nordor, A.V.; Nehar-Belaid, D.; Richon, S.; Klatzmann, D.; Bellet, D.; Dangles-Marie, V.; Fournier, T.; Aryee, M.J. The early pregnancy placenta foreshadows DNA methylation alterations of solid tumors. Epigenetics 2017, 12, 793-803. [CrossRef] [PubMed]

53. Yuen, R.K.; Chen, B.; Blair, J.D.; Robinson, W.P.; Nelson, D.M. Hypoxia alters the epigenetic profile in cultured human placental trophoblasts. Epigenetics 2013, 8, 192-202. [CrossRef] [PubMed]

54. Shankar, K.; Kang, P.; Zhong, Y.; Borengasser, S.J.; Wingfield, C.; Saben, J.; Gomez-Acevedo, H.; Thakali, K.M. Transcriptomic and epigenomic landscapes during cell fusion in BeWo trophoblast cells. Placenta 2015, 36, 1342-1351. [CrossRef] [PubMed]

55. James, J.L.; Hurley, D.G.; Gamage, T.K.; Zhang, T.; Vather, R.; Pantham, P.; Murthi, P.; Chamley, L.W. Isolation and characterisation of a novel trophoblast side-population from first trimester placentae. Reproduction 2015, 150, 449-462. [CrossRef] [PubMed]

56. Gamage, T.K.; Schierding, W.; Hurley, D.; Tsai, P.; Ludgate, J.L.; Bhoothpur, C.; Chamley, L.W.; Weeks, R.J.; Macaulay, E.C.; James, J.L. The role of DNA methylation in human trophoblast differentiation. Epigenetics 2018. [CrossRef] [PubMed]

57. Ng, R.K.; Dean, W.; Dawson, C.; Lucifero, D.; Madeja, Z.; Reik, W.; Hemberger, M. Epigenetic restriction of embryonic cell lineage fate by methylation of Elf5. Nat. Cell Biol. 2008, 10, 1280-1290. [CrossRef] [PubMed]

58. Senner, C.E.; Krueger, F.; Oxley, D.; Andrews, S.; Hemberger, M. DNA methylation profiles define stem cell identity and reveal a tight embryonic-extraembryonic lineage boundary. Stem Cells 2012, 30, 2732-2745. [CrossRef]

59. Murray, R.; Bryant, J.; Titcombe, P.; Barton, S.J.; Inskip, H.; Harvey, N.C.; Cooper, C.; Lillycrop, K.; Hanson, M.; Godfrey, K.M. DNA methylation at birth within the promoter of ANRIL predicts markers of cardiovascular risk at 9 years. Clin. Epigenet. 2016, 8, 90. [CrossRef]

60. Santos, J.; Pereira, C.F.; Di-Gregorio, A.; Spruce, T.; Alder, O.; Rodriguez, T.; Azuara, V.; Merkenschlager, M.; Fisher, A.G. Differences in the epigenetic and reprogramming properties of pluripotent and extra-embryonic stem cells implicate chromatin remodelling as an important early event in the developing mouse embryo. Epigenet. Chromatin 2010, 3, 1. [CrossRef]

61. Bianco-Miotto, T.; Mayne, B.T.; Buckberry, S.; Breen, J.; Rodriguez Lopez, C.M.; Roberts, C.T. Recent progress towards understanding the role of DNA methylation in human placental development. Reproduction 2016, 152, R23-R30. [CrossRef] [PubMed]

62. Ou, X.; Wang, H.; Qu, D.; Chen, Y.; Gao, J.; Sun, H. Epigenome-wide DNA methylation assay reveals placental epigenetic markers for noninvasive fetal single-nucleotide polymorphism genotyping in maternal plasma. Transfusion 2014, 54, 2523-2533. [CrossRef] [PubMed] 
63. Xiang, Y.; Zhang, J.; Li, Q.; Zhou, X.; Wang, T.; Xu, M.; Xia, S.; Xing, Q.; Wang, L.; He, L.; et al. DNA methylome profiling of maternal peripheral blood and placentas reveal potential fetal DNA markers for non-invasive prenatal testing. Mol. Hum. Reprod. 2014, 20, 875-884. [CrossRef] [PubMed]

64. Novakovic, B.; Yuen, R.K.; Gordon, L.; Penaherrera, M.S.; Sharkey, A.; Moffett, A.; Craig, J.M.; Robinson, W.P.; Saffery, R. Evidence for widespread changes in promoter methylation profile in human placenta in response to increasing gestational age and environmental/stochastic factors. BMC Genom. 2011, 12, 529. [CrossRef] [PubMed]

65. Rakyan, V.K.; Down, T.A.; Thorne, N.P.; Flicek, P.; Kulesha, E.; Graf, S.; Tomazou, E.M.; Backdahl, L.; Johnson, N.; Herberth, M.; et al. An integrated resource for genome-wide identification and analysis of human tissue-specific differentially methylated regions (tDMRs). Genome Res. 2008, 18, 1518-1529. [CrossRef] [PubMed]

66. Kaur, G.; Helmer, R.A.; Smith, L.A.; Martinez-Zaguilan, R.; Dufour, J.M.; Chilton, B.S. Alternative splicing of helicase-like transcription factor (Hltf): Intron retention-dependent activation of immune tolerance at the feto-maternal interface. PLoS ONE 2018, 13, e0200211. [CrossRef] [PubMed]

67. Schmidt, M.; Lax, E.; Zhou, R.; Cheishvili, D.; Ruder, A.M.; Ludiro, A.; Lapert, F.; Macedo da Cruz, A.; Sandrini, P.; Calzoni, T.; et al. Fetal glucocorticoid receptor ( $\mathrm{Nr} 3 \mathrm{c} 1$ ) deficiency alters the landscape of DNA methylation of murine placenta in a sex-dependent manner and is associated to anxiety-like behavior in adulthood. Transl. Psychiatry 2019, 9, 23. [CrossRef]

68. Price, E.M.; Cotton, A.M.; Penaherrera, M.S.; McFadden, D.E.; Kobor, M.S.; Robinson, W. Different measures of "genome-wide" DNA methylation exhibit unique properties in placental and somatic tissues. Epigenetics 2012, 7, 652-663. [CrossRef] [PubMed]

69. Yang, A.; Sun, Y.; Mao, C.; Yang, S.; Huang, M.; Deng, M.; Ding, N.; Yang, X.; Zhang, M.; Jin, S.; et al. Folate Protects Hepatocytes of Hyperhomocysteinemia Mice From Apoptosis via Cystic Fibrosis Transmembrane Conductance Regulator (CFTR)-Activated Endoplasmic Reticulum Stress. J. Cell. Biochem. 2017, 118, 2921-2932. [CrossRef] [PubMed]

70. Hernandez Mora, J.R.; Sanchez-Delgado, M.; Petazzi, P.; Moran, S.; Esteller, M.; Iglesias-Platas, I.; Monk, D. Profiling of oxBS-450K 5-hydroxymethylcytosine in human placenta and brain reveals enrichment at imprinted loci. Epigenetics 2018, 13, 182-191. [CrossRef]

71. Lim, Y.C.; Li, J.; Ni, Y.; Liang, Q.; Zhang, J.; Yeo, G.S.H.; Lyu, J.; Jin, S.; Ding, C. A complex association between DNA methylation and gene expression in human placenta at first and third trimesters. PLoS ONE 2017, 12, e0181155. [CrossRef] [PubMed]

72. Roost, M.S.; Slieker, R.C.; Bialecka, M.; van Iperen, L.; Gomes Fernandes, M.M.; He, N.; Suchiman, H.E.D.; Szuhai, K.; Carlotti, F.; de Koning, E.J.P.; et al. DNA methylation and transcriptional trajectories during human development and reprogramming of isogenic pluripotent stem cells. Nat. Commun. 2017, 8, 908. [CrossRef] [PubMed]

73. Decato, B.E.; Lopez-Tello, J.; Sferruzzi-Perri, A.N.; Smith, A.D.; Dean, M.D. DNA Methylation Divergence and Tissue Specialization in the Developing Mouse Placenta. Mol. Biol. Evol. 2017, 34, 1702-1712. [CrossRef] [PubMed]

74. Green, B.B.; Houseman, E.A.; Johnson, K.C.; Guerin, D.J.; Armstrong, D.A.; Christensen, B.C.; Marsit, C.J. Hydroxymethylation is uniquely distributed within term placenta, and is associated with gene expression. FASEB J. 2016, 30, 2874-2884. [CrossRef] [PubMed]

75. Chatterjee, A.; Macaulay, E.C.; Rodger, E.J.; Stockwell, P.A.; Parry, M.F.; Roberts, H.E.; Slatter, T.L.; Hung, N.A.; Devenish, C.J.; Morison, I.M. Placental Hypomethylation Is More Pronounced in Genomic Loci Devoid of Retroelements. G3 (Bethesda) 2016, 6, 1911-1921. [CrossRef] [PubMed]

76. Branco, M.R.; King, M.; Perez-Garcia, V.; Bogutz, A.B.; Caley, M.; Fineberg, E.; Lefebvre, L.; Cook, S.J.; Dean, W.; Hemberger, M.; et al. Maternal DNA Methylation Regulates Early Trophoblast Development. Dev. Cell 2016, 36, 152-163. [CrossRef] [PubMed]

77. Hanna, C.W.; Penaherrera, M.S.; Saadeh, H.; Andrews, S.; McFadden, D.E.; Kelsey, G.; Robinson, W.P. Pervasive polymorphic imprinted methylation in the human placenta. Genome Res. 2016, 26, 756-767. [CrossRef] [PubMed]

78. Hu, Y.; Blair, J.D.; Yuen, R.K.; Robinson, W.P.; von Dadelszen, P. Genome-wide DNA methylation identifies trophoblast invasion-related genes: Claudin-4 and Fucosyltransferase IV control mobility via altering matrix metalloproteinase activity. Mol. Hum. Reprod. 2015, 21, 452-465. [CrossRef] 
79. Mahadevan, S.; Wen, S.; Wan, Y.W.; Peng, H.H.; Otta, S.; Liu, Z.; Iacovino, M.; Mahen, E.M.; Kyba, M.; Sadikovic, B.; et al. NLRP7 affects trophoblast lineage differentiation, binds to overexpressed YY1 and alters CpG methylation. Hum. Mol. Genet. 2014, 23, 706-716. [CrossRef] [PubMed]

80. Novakovic, B.; Gordon, L.; Wong, N.C.; Moffett, A.; Manuelpillai, U.; Craig, J.M.; Sharkey, A.; Saffery, R. Wide-ranging DNA methylation differences of primary trophoblast cell populations and derived cell lines: Implications and opportunities for understanding trophoblast function. Mol. Hum. Reprod. 2011, 17, 344-353. [CrossRef] [PubMed]

81. Amorim, R.P.; Araujo, M.G.L.; Valero, J.; Lopes-Cendes, I.; Pascoal, V.D.B.; Malva, J.O.; da Silva Fernandes, M.J. Silencing of P2X7R by RNA interference in the hippocampus can attenuate morphological and behavioral impact of pilocarpine-induced epilepsy. Purinergic Signal. 2017, 13, 467-478. [CrossRef] [PubMed]

82. Oudejans, C.B.; Pannese, M.; Simeone, A.; Meijer, C.J.; Boncinelli, E. The three most downstream genes of the Hox-3 cluster are expressed in human extraembryonic tissues including trophoblast of androgenetic origin. Development 1990, 108, 471-477. [PubMed]

83. Chui, A.; Pathirage, N.A.; Johnson, B.; Cocquebert, M.; Fournier, T.; Evain-Brion, D.; Roald, B.; Manuelpillai, U.; Brennecke, S.P.; Kalionis, B.; et al. Homeobox gene distal-less 3 is expressed in proliferating and differentiating cells of the human placenta. Placenta 2010, 31, 691-697. [CrossRef] [PubMed]

84. Grati, F.R.; Sirchia, S.M.; Gentilin, B.; Rossella, F.; Ramoscelli, L.; Antonazzo, P.; Cavallari, U.; Bulfamante, G.; Cetin, I.; Simoni, G.; et al. Biparental expression of ESX1L gene in placentas from normal and intrauterine growth-restricted pregnancies. Eur. J. Hum. Genet. 2004, 12, 272-278. [CrossRef] [PubMed]

85. Quinn, L.M.; Johnson, B.V.; Nicholl, J.; Sutherland, G.R.; Kalionis, B. Isolation and identification of homeobox genes from the human placenta including a novel member of the Distal-less family, DLX4. Gene 1997, 187, 55-61. [CrossRef]

86. Rajaraman, G.; Murthi, P.; Quinn, L.; Brennecke, S.P.; Kalionis, B. Homeodomain protein HLX is expressed primarily in cytotrophoblast cell types in the early pregnancy human placenta. Reprod. Fertil. Dev. 2008, 20, 357-367. [CrossRef] [PubMed]

87. Schroeder, D.I.; LaSalle, J.M. How has the study of the human placenta aided our understanding of partially methylated genes? Epigenomics 2013, 5, 645-654. [CrossRef] [PubMed]

88. Hombach, S.; Kretz, M. Non-coding RNAs: Classification, Biology and Functioning. Adv. Exp. Med. Biol. 2016, 937, 3-17. [PubMed]

89. Sadovsky, Y.; Mouillet, J.F.; Ouyang, Y.; Bayer, A.; Coyne, C.B. The Function of TrophomiRs and Other MicroRNAs in the Human Placenta. Cold Spring Harb. Perspect. Med. 2015, 5, a023036. [CrossRef] [PubMed]

90. Guo, H.; Ingolia, N.T.; Weissman, J.S.; Bartel, D.P. Mammalian microRNAs predominantly act to decrease target mRNA levels. Nature 2010, 466, 835-840. [CrossRef]

91. Krol, J.; Loedige, I.; Filipowicz, W. The widespread regulation of microRNA biogenesis, function and decay. Nat. Rev. Genet. 2010, 11, 597-610. [CrossRef] [PubMed]

92. Bentwich, I.; Avniel, A.; Karov, Y.; Aharonov, R.; Gilad, S.; Barad, O.; Barzilai, A.; Einat, P.; Einav, U.; Meiri, E.; et al. Identification of hundreds of conserved and nonconserved human microRNAs. Nat. Genet. 2005, 37, 766-770. [CrossRef] [PubMed]

93. Donker, R.B.; Mouillet, J.F.; Chu, T.; Hubel, C.A.; Stolz, D.B.; Morelli, A.E.; Sadovsky, Y. The expression profile of C19MC microRNAs in primary human trophoblast cells and exosomes. Mol. Hum. Reprod. 2012, 18, 417-424. [CrossRef] [PubMed]

94. Zhang, R.; Wang, Y.Q.; Su, B. Molecular evolution of a primate-specific microRNA family. Mol. Biol. Evol. 2008, 25, 1493-1502. [CrossRef] [PubMed]

95. Noguer-Dance, M.; Abu-Amero, S.; Al-Khtib, M.; Lefevre, A.; Coullin, P.; Moore, G.E.; Cavaille, J. The primate-specific microRNA gene cluster (C19MC) is imprinted in the placenta. Hum. Mol. Genet. 2010, 19, 3566-3582. [CrossRef] [PubMed]

96. Tsai, K.W.; Kao, H.W.; Chen, H.C.; Chen, S.J.; Lin, W.C. Epigenetic control of the expression of a primate-specific microRNA cluster in human cancer cells. Epigenetics 2009, 4, 587-592. [CrossRef]

97. Bar, M.; Wyman, S.K.; Fritz, B.R.; Qi, J.; Garg, K.S.; Parkin, R.K.; Kroh, E.M.; Bendoraite, A.; Mitchell, P.S.; Nelson, A.M.; et al. MicroRNA discovery and profiling in human embryonic stem cells by deep sequencing of small RNA libraries. Stem Cells 2008, 26, 2496-2505. [CrossRef] [PubMed] 
98. Laurent, L.C.; Chen, J.; Ulitsky, I.; Mueller, F.J.; Lu, C.; Shamir, R.; Fan, J.B.; Loring, J.F. Comprehensive microRNA profiling reveals a unique human embryonic stem cell signature dominated by a single seed sequence. Stem Cells 2008, 26, 1506-1516. [CrossRef] [PubMed]

99. Morin, R.D.; O'Connor, M.D.; Griffith, M.; Kuchenbauer, F.; Delaney, A.; Prabhu, A.L.; Zhao, Y.; McDonald, H.; Zeng, T.; Hirst, M.; et al. Application of massively parallel sequencing to microRNA profiling and discovery in human embryonic stem cells. Genome Res. 2008, 18, 610-621. [CrossRef] [PubMed]

100. Ren, J.; Jin, P.; Wang, E.; Marincola, F.M.; Stroncek, D.F. MicroRNA and gene expression patterns in the differentiation of human embryonic stem cells. J. Transl. Med. 2009, 7, 20. [CrossRef] [PubMed]

101. Stadler, B.; Ivanovska, I.; Mehta, K.; Song, S.; Nelson, A.; Tan, Y.; Mathieu, J.; Darby, C.; Blau, C.A.; Ware, C.; et al. Characterization of microRNAs involved in embryonic stem cell states. Stem Cells Dev. 2010, 19, 935-950. [CrossRef]

102. Morales-Prieto, D.M.; Ospina-Prieto, S.; Chaiwangyen, W.; Schoenleben, M.; Markert, U.R. Pregnancy-associated miRNA-clusters. J. Reprod. Immunol. 2013, 97, 51-61. [CrossRef] [PubMed]

103. Gu, Y.; Sun, J.; Groome, L.J.; Wang, Y. Differential miRNA expression profiles between the first and third trimester human placentas. Am. J. Physiol. Endocrinol. Metab. 2013, 304, E836-E843. [CrossRef] [PubMed]

104. Liang, Y.; Ridzon, D.; Wong, L.; Chen, C. Characterization of microRNA expression profiles in normal human tissues. BMC Genom. 2007, 8, 166. [CrossRef] [PubMed]

105. Keniry, A.; Oxley, D.; Monnier, P.; Kyba, M.; Dandolo, L.; Smits, G.; Reik, W. The H19 lincRNA is a developmental reservoir of miR-675 that suppresses growth and Igf1r. Nat. Cell Biol. 2012, 14, 659-665. [CrossRef] [PubMed]

106. Forbes, K.; Farrokhnia, F.; Aplin, J.D.; Westwood, M. Dicer-dependent miRNAs provide an endogenous restraint on cytotrophoblast proliferation. Placenta 2012, 33, 581-585. [CrossRef] [PubMed]

107. Doridot, L.; Miralles, F.; Barbaux, S.; Vaiman, D. Trophoblasts, invasion, and microRNA. Front. Genet. 2013, 4, 248. [CrossRef] [PubMed]

108. Yang, X.; Meng, T. MicroRNA-431 affects trophoblast migration and invasion by targeting ZEB1 in preeclampsia. Gene 2019, 683, 225-232. [CrossRef] [PubMed]

109. Ransohoff, J.D.; Wei, Y.; Khavari, P.A. The functions and unique features of long intergenic non-coding RNA. Nat. Rev. Mol. Cell Biol. 2018, 19, 143-157. [CrossRef] [PubMed]

110. McAninch, D.; Roberts, C.T.; Bianco-Miotto, T. Mechanistic Insight into Long Noncoding RNAs and the Placenta. Int. J. Mol. Sci. 2017, 18, 1371. [CrossRef]

111. Brannan, C.I.; Dees, E.C.; Ingram, R.S.; Tilghman, S.M. The product of the H19 gene may function as an RNA. Mol. Cell. Biol. 1990, 10, 28-36. [CrossRef] [PubMed]

112. Gabory, A.; Jammes, H.; Dandolo, L. The H19 locus: Role of an imprinted non-coding RNA in growth and development. Bioessays 2010, 32, 473-480. [CrossRef] [PubMed]

113. Iglesias-Platas, I.; Martin-Trujillo, A.; Petazzi, P.; Guillaumet-Adkins, A.; Esteller, M.; Monk, D. Altered expression of the imprinted transcription factor PLAGL1 deregulates a network of genes in the human IUGR placenta. Hum. Mol. Genet. 2014, 23, 6275-6285. [CrossRef] [PubMed]

114. Kallen, A.N.; Zhou, X.B.; Xu, J.; Qiao, C.; Ma, J.; Yan, L.; Lu, L.; Liu, C.; Yi, J.S.; Zhang, H.; et al. The imprinted H19 lncRNA antagonizes let-7 microRNAs. Mol. Cell 2013, 52, 101-112. [CrossRef] [PubMed]

115. Jinno, Y.; Ikeda, Y.; Yun, K.; Maw, M.; Masuzaki, H.; Fukuda, H.; Inuzuka, K.; Fujishita, A.; Ohtani, Y.; Okimoto, T; et al. Establishment of functional imprinting of the $\mathrm{H} 19$ gene in human developing placentae. Nat. Genet. 1995, 10, 318-324. [CrossRef]

116. Yu, L.; Chen, M.; Zhao, D.; Yi, P.; Lu, L.; Han, J.; Zheng, X.; Zhou, Y.; Li, L. The H19 gene imprinting in normal pregnancy and pre-eclampsia. Placenta 2009, 30, 443-447. [CrossRef]

117. Jenuwein, T.; Allis, C.D. Translating the histone code. Science 2001, 293, 1074-1080. [CrossRef]

118. Mellor, J.; Dudek, P.; Clynes, D. A glimpse into the epigenetic landscape of gene regulation. Curr. Opin. Genet. Dev. 2008, 18, 116-122. [CrossRef]

119. Grewal, S.I.; Jia, S. Heterochromatin revisited. Nat. Rev. Genet. 2007, 8, 35-46. [CrossRef]

120. Torres-Padilla, M.E.; Parfitt, D.E.; Kouzarides, T.; Zernicka-Goetz, M. Histone arginine methylation regulates pluripotency in the early mouse embryo. Nature 2007, 445, 214-218. [CrossRef]

121. Semenza, G.L. HIF-1 and mechanisms of hypoxia sensing. Curr. Opin. Cell Biol. 2001, 13, 167-171. [CrossRef] 
122. Charron, C.E.; Chou, P.C.; Coutts, D.J.; Kumar, V.; To, M.; Akashi, K.; Pinhu, L.; Griffiths, M.; Adcock, I.M.; Barnes, P.J.; et al. Hypoxia-inducible factor 1alpha induces corticosteroid-insensitive inflammation via reduction of histone deacetylase-2 transcription. J. Biol. Chem. 2009, 284, 36047-36054. [CrossRef] [PubMed]

123. Maltepe, E.; Krampitz, G.W.; Okazaki, K.M.; Red-Horse, K.; Mak, W.; Simon, M.C.; Fisher, S.J. Hypoxia-inducible factor-dependent histone deacetylase activity determines stem cell fate in the placenta. Development 2005, 132, 3393-3403. [CrossRef] [PubMed]

124. Pollard, P.J.; Loenarz, C.; Mole, D.R.; McDonough, M.A.; Gleadle, J.M.; Schofield, C.J.; Ratcliffe, P.J. Regulation of Jumonji-domain-containing histone demethylases by hypoxia-inducible factor (HIF)-1alpha. Biochem. J. 2008, 416, 387-394. [CrossRef] [PubMed]

125. Wellmann, S.; Bettkober, M.; Zelmer, A.; Seeger, K.; Faigle, M.; Eltzschig, H.K.; Buhrer, C. Hypoxia upregulates the histone demethylase JMJD1A via HIF-1. Biochem. Biophys. Res. Commun. 2008, 372, 892-897. [CrossRef] [PubMed]

126. Xia, M.; Yao, L.; Zhang, Q.; Wang, F.; Mei, H.; Guo, X.; Huang, W. Long noncoding RNA HOTAIR promotes metastasis of renal cell carcinoma by up-regulating histone H3K27 demethylase JMJD3. Oncotarget 2017, 8, 19795-19802. [CrossRef] [PubMed]

127. Maltepe, E.; Bakardjiev, A.I.; Fisher, S.J. The placenta: Transcriptional, epigenetic, and physiological integration during development. J. Clin. Investig. 2010, 120, 1016-1025. [CrossRef] [PubMed]

128. Franasiak, J.M.; Scott, R.T. Contribution of immunology to implantation failure of euploid embryos. Fertil. Steril. 2017, 107, 1279-1283. [CrossRef] [PubMed]

129. Griffith, O.W.; Chavan, A.R.; Protopapas, S.; Maziarz, J.; Romero, R.; Wagner, G.P. Embryo implantation evolved from an ancestral inflammatory attachment reaction. Proc. Natl. Acad. Sci. USA 2017, 114, E6566-E6575. [CrossRef] [PubMed]

130. Hansen, V.L.; Faber, L.S.; Salehpoor, A.A.; Miller, R.D. A pronounced uterine pro-inflammatory response at parturition is an ancient feature in mammals. Proc. Biol. Sci. 2017, 284, 20171694. [CrossRef] [PubMed]

131. Cornelis, G.; Funk, M.; Vernochet, C.; Leal, F.; Tarazona, O.A.; Meurice, G.; Heidmann, O.; Dupressoir, A.; Miralles, A.; Ramirez-Pinilla, M.P.; et al. An endogenous retroviral envelope syncytin and its cognate receptor identified in the viviparous placental Mabuya lizard. Proc. Natl. Acad. Sci. USA 2017, 114, E10991-E11000. [CrossRef] [PubMed]

132. McKinnell, Z.; Wessel, G. Ligers and tigons and.....what?....oh my! Mol. Reprod. Dev. 2012, 79, Fm i. [CrossRef] [PubMed]

133. Surani, M.A.; Barton, S.C.; Norris, M.L. Development of reconstituted mouse eggs suggests imprinting of the genome during gametogenesis. Nature 1984, 308, 548-550. [CrossRef] [PubMed]

134. Wake, N.; Arima, T.; Matsuda, T. Involvement of IGF2 and H19 imprinting in choriocarcinoma development. Int. J. Gynaecol. Obstet. 1998, 60 (Suppl. 1), S1-S8. [CrossRef]

135. Warren, W.C.; Hillier, L.W.; Marshall Graves, J.A.; Birney, E.; Ponting, C.P.; Grutzner, F.; Belov, K.; Miller, W.; Clarke, L.; Chinwalla, A.T.; et al. Genome analysis of the platypus reveals unique signatures of evolution. Nature 2008, 453, 175-183. [CrossRef] [PubMed]

136. Suzuki, S.; Shaw, G.; Kaneko-Ishino, T.; Ishino, F.; Renfree, M.B. The evolution of mammalian genomic imprinting was accompanied by the acquisition of novel CpG islands. Genome Biol. Evol. 2011, 3, 1276-1283. [CrossRef] [PubMed]

137. Renfree, M.B.; Suzuki, S.; Kaneko-Ishino, T. The origin and evolution of genomic imprinting and viviparity in mammals. Philos. Trans. R. Soc. Lond. B Biol. Sci. 2013, 368, 20120151. [CrossRef] [PubMed]

138. Fresard, L.; Leroux, S.; Servin, B.; Gourichon, D.; Dehais, P.; Cristobal, M.S.; Marsaud, N.; Vignoles, F.; Bed'hom, B.; Coville, J.L.; et al. Transcriptome-wide investigation of genomic imprinting in chicken. Nucleic Acids Res. 2014, 42, 3768-3782. [CrossRef] [PubMed]

139. Zhuo, Z.; Lamont, S.J.; Abasht, B. RNA-Seq Analyses Identify Frequent Allele Specific Expression and No Evidence of Genomic Imprinting in Specific Embryonic Tissues of Chicken. Sci. Rep. 2017, 7, 11944. [CrossRef] [PubMed]

140. Piedrahita, J.A. The role of imprinted genes in fetal growth abnormalities. Birth Defects Res. A Clin. Mol. Teratol. 2011, 91, 682-692. [CrossRef] [PubMed]

141. Constancia, M.; Hemberger, M.; Hughes, J.; Dean, W.; Ferguson-Smith, A.; Fundele, R.; Stewart, F.; Kelsey, G.; Fowden, A.; Sibley, C.; et al. Placental-specific IGF-II is a major modulator of placental and fetal growth. Nature 2002, 417, 945-948. [CrossRef] [PubMed] 
142. Ripoche, M.A.; Kress, C.; Poirier, F.; Dandolo, L. Deletion of the H19 transcription unit reveals the existence of a putative imprinting control element. Genes Dev. 1997, 11, 1596-1604. [CrossRef] [PubMed]

143. Xu, Y.; Goodyer, C.G.; Deal, C.; Polychronakos, C. Functional polymorphism in the parental imprinting of the human IGF2R gene. Biochem. Biophys. Res. Commun. 1993, 197, 747-754. [CrossRef] [PubMed]

144. Cheong, C.Y.; Chng, K.; Ng, S.; Chew, S.B.; Chan, L.; Ferguson-Smith, A.C. Germline and somatic imprinting in the nonhuman primate highlights species differences in oocyte methylation. Genome Res. 2015, 25, 611-623. [CrossRef] [PubMed]

145. Monk, D.; Arnaud, P.; Apostolidou, S.; Hills, F.A.; Kelsey, G.; Stanier, P.; Feil, R.; Moore, G.E. Limited evolutionary conservation of imprinting in the human placenta. Proc. Natl. Acad. Sci. USA 2006, 103, 6623-6628. [CrossRef]

146. Barbaux, S.; Gascoin-Lachambre, G.; Buffat, C.; Monnier, P.; Mondon, F.; Tonanny, M.B.; Pinard, A.; Auer, J.; Bessieres, B.; Barlier, A.; et al. A genome-wide approach reveals novel imprinted genes expressed in the human placenta. Epigenetics 2012, 7, 1079-1090. [CrossRef]

147. Allach El Khattabi, L.; Backer, S.; Pinard, A.; Dieudonne, M.N.; Tsatsaris, V.; Vaiman, D.; Dandolo, L.; Bloch-Gallego, E.; Jammes, H.; Barbaux, S. A genome-wide search for new imprinted genes in the human placenta identifies DSCAM as the first imprinted gene on chromosome 21. Eur. J. Hum. Genet. 2019, 27, 49-60. [CrossRef]

148. Marjonen, H.; Auvinen, P.; Kahila, H.; Tsuiko, O.; Koks, S.; Tiirats, A.; Viltrop, T.; Tuuri, T.; Soderstrom-Anttila, V.; Suikkari, A.M.; et al. rs10732516 polymorphism at the IGF2/H19 locus associates with genotype-specific effects on placental DNA methylation and birth weight of newborns conceived by assisted reproductive technology. Clin. Epigenet. 2018, 10, 80. [CrossRef]

149. Peters, J. The role of genomic imprinting in biology and disease: An expanding view. Nat. Rev. Genet. 2014, 15, 517-530. [CrossRef]

150. Monk, D. Genomic imprinting in the human placenta. Am. J. Obstet. Gynecol. 2015, 213, S152-S162. [CrossRef]

151. Christians, J.K.; Leavey, K.; Cox, B.J. Associations between imprinted gene expression in the placenta, human fetal growth and preeclampsia. Biol. Lett. 2017, 13, 20170643. [CrossRef] [PubMed]

152. Xie, L.; Sadovsky, Y. The function of miR-519d in cell migration, invasion, and proliferation suggests a role in early placentation. Placenta 2016, 48, 34-37. [CrossRef] [PubMed]

153. Petre, G.; Lores, P.; Sartelet, H.; Truffot, A.; Poreau, B.; Brandeis, S.; Martinez, G.; Satre, V.; Harbuz, R.; Ray, P.F.; et al. Genomic duplication in the 19q13.42 imprinted region identified as a new genetic cause of intrauterine growth restriction. Clin. Genet. 2018. [CrossRef] [PubMed]

154. Vaiman, D.; Calicchio, R.; Miralles, F. Landscape of transcriptional deregulations in the preeclamptic placenta. PLoS ONE 2013, 8, e65498. [CrossRef] [PubMed]

155. Jia, R.Z.; Zhang, X.; Hu, P.; Liu, X.M.; Hua, X.D.; Wang, X.; Ding, H.J. Screening for differential methylation status in human placenta in preeclampsia using a $\mathrm{CpG}$ island plus promoter microarray. Int. J. Mol. Med. 2012, 30, 133-141.

156. Anton, L.; Olarerin-George, A.O.; Schwartz, N.; Srinivas, S.; Bastek, J.; Hogenesch, J.B.; Elovitz, M.A. miR-210 inhibits trophoblast invasion and is a serum biomarker for preeclampsia. Am. J. Pathol. 2013, 183, 1437-1445. [CrossRef]

157. Liu, L.; Zhang, X.; Rong, C.; Rui, C.; Ji, H.; Qian, Y.J.; Jia, R.; Sun, L. Distinct DNA methylomes of human placentas between pre-eclampsia and gestational diabetes mellitus. Cell. Physiol. Biochem. 2014, 34, 1877-1889. [CrossRef]

158. Yeung, K.R.; Chiu, C.L.; Pidsley, R.; Makris, A.; Hennessy, A.; Lind, J.M. DNA methylation profiles in preeclampsia and healthy control placentas. Am. J. Physiol. Heart Circ. Physiol. 2016, 310, H1295-H1303. [CrossRef]

159. Zhu, Y.; Song, X.; Wang, J.; Li, Y.; Yang, Y.; Yang, T.; Ma, H.; Wang, L.; Zhang, G.; Cho, W.C.; et al. Placental mesenchymal stem cells of fetal origin deposit epigenetic alterations during long-term culture under serum-free condition. Expert Opin. Biol. Ther. 2015, 15, 163-180. [CrossRef]

160. Leavey, K.; Wilson, S.L.; Bainbridge, S.A.; Robinson, W.P.; Cox, B.J. Epigenetic regulation of placental gene expression in transcriptional subtypes of preeclampsia. Clin. Epigenet. 2018, 10, 28. [CrossRef]

161. Calicchio, R.; Doridot, L.; Miralles, F.; Mehats, C.; Vaiman, D. DNA methylation, an epigenetic mode of gene expression regulation in reproductive science. Curr. Pharm. Des. 2014, 20, 1726-1750. [CrossRef] [PubMed] 
162. Horiuchi, A.; Hayashi, T.; Kikuchi, N.; Hayashi, A.; Fuseya, C.; Shiozawa, T.; Konishi, I. Hypoxia upregulates ovarian cancer invasiveness via the binding of HIF-1alpha to a hypoxia-induced, methylation-free hypoxia response element of S100A4 gene. Int. J. Cancer 2012, 131, 1755-1767. [CrossRef] [PubMed]

163. Aouache, R.; Biquard, L.; Vaiman, D.; Miralles, F. Oxidative Stress in Preeclampsia and Placental Diseases. Int. J. Mol. Sci. 2018, 19, 1496. [CrossRef] [PubMed]

164. Biron-Shental, T.; Sukenik Halevy, R.; Goldberg-Bittman, L.; Kidron, D.; Fejgin, M.D.; Amiel, A. Telomeres are shorter in placental trophoblasts of pregnancies complicated with intrauterine growth restriction (IUGR). Early Hum. Dev. 2010, 86, 451-456. [CrossRef] [PubMed]

165. Sukenik-Halevy, R.; Amiel, A.; Kidron, D.; Liberman, M.; Ganor-Paz, Y.; Biron-Shental, T. Telomere homeostasis in trophoblasts and in cord blood cells from pregnancies complicated with preeclampsia. Am. J. Obstet. Gynecol. 2016, 214, 283.e1-283.e7. [CrossRef]

166. Farladansky-Gershnabel, S.; Gal, H.; Kidron, D.; Krizhanovsky, V.; Amiel, A.; Sukenik-Halevy, R.; Biron-Shental, T. Telomere Homeostasis and Senescence Markers Are Differently Expressed in Placentas From Pregnancies With Early- Versus Late-Onset Preeclampsia. Reprod. Sci. 2018, 1933719118811644. [CrossRef]

167. Cindrova-Davies, T.; Fogarty, N.M.E.; Jones, C.J.P.; Kingdom, J.; Burton, G.J. Evidence of oxidative stress-induced senescence in mature, post-mature and pathological human placentas. Placenta 2018, 68, 15-22. [CrossRef]

168. Londero, A.P.; Orsaria, M.; Marzinotto, S.; Grassi, T.; Fruscalzo, A.; Calcagno, A.; Bertozzi, S.; Nardini, N.; Stella, E.; Lelle, R.J.; et al. Placental aging and oxidation damage in a tissue micro-array model: An immunohistochemistry study. Histochem. Cell Biol. 2016, 146, 191-204. [CrossRef]

169. Burton, G.J.; Yung, H.W.; Murray, A.J. Mitochondrial-Endoplasmic reticulum interactions in the trophoblast: Stress and senescence. Placenta 2017, 52, 146-155. [CrossRef]

170. Chu, T.; Bunce, K.; Shaw, P.; Shridhar, V.; Althouse, A.; Hubel, C.; Peters, D. Comprehensive analysis of preeclampsia-associated DNA methylation in the placenta. PLoS ONE 2014, 9, e107318. [CrossRef]

171. Blair, J.D.; Yuen, R.K.; Lim, B.K.; McFadden, D.E.; von Dadelszen, P.; Robinson, W.P. Widespread DNA hypomethylation at gene enhancer regions in placentas associated with early-onset pre-eclampsia. Mol. Hum. Reprod. 2013, 19, 697-708. [CrossRef] [PubMed]

172. Yung, H.W.; Atkinson, D.; Campion-Smith, T.; Olovsson, M.; Charnock-Jones, D.S.; Burton, G.J. Differential activation of placental unfolded protein response pathways implies heterogeneity in causation of early- and late-onset pre-eclampsia. J. Pathol. 2014, 234, 262-276. [CrossRef] [PubMed]

173. Zhu, L.; Lv, R.; Kong, L.; Cheng, H.; Lan, F.; Li, X. Genome-Wide Mapping of 5mC and 5hmC Identified Differentially Modified Genomic Regions in Late-Onset Severe Preeclampsia: A Pilot Study. PLoS ONE 2015, 10, e0134119. [CrossRef] [PubMed]

174. Anton, L.; Brown, A.G.; Bartolomei, M.S.; Elovitz, M.A. Differential methylation of genes associated with cell adhesion in preeclamptic placentas. PLoS ONE 2014, 9, e100148. [CrossRef] [PubMed]

175. Nie, X.; Zhang, K.; Wang, L.; Ou, G.; Zhu, H.; Gao, W.Q. Transcription factor STOX1 regulates proliferation of inner ear epithelial cells via the AKT pathway. Cell Prolif. 2015, 48, 209-220. [CrossRef] [PubMed]

176. Guibert, S.; Weber, M. Functions of DNA methylation and hydroxymethylation in mammalian development. Curr. Top. Dev. Biol. 2013, 104, 47-83. [PubMed]

177. Bellido, M.L.; Radpour, R.; Lapaire, O.; De Bie, I.; Hosli, I.; Bitzer, J.; Hmadcha, A.; Zhong, X.Y.; Holzgreve, W. MALDI-TOF mass array analysis of RASSF1A and SERPINB5 methylation patterns in human placenta and plasma. Biol. Reprod. 2010, 82, 745-750. [CrossRef] [PubMed]

178. Anderson, C.M.; Ralph, J.L.; Wright, M.L.; Linggi, B.; Ohm, J.E. DNA methylation as a biomarker for preeclampsia. Biol. Res. Nurs. 2014, 16, 409-420. [CrossRef] [PubMed]

179. He, J.; Zhang, A.; Fang, M.; Fang, R.; Ge, J.; Jiang, Y.; Zhang, H.; Han, C.; Ye, X.; Yu, D.; et al. Methylation levels at IGF2 and GNAS DMRs in infants born to preeclamptic pregnancies. BMC Genom. 2013, 14, 472. [CrossRef]

180. Xiang, Y.; Zhang, X.; Li, Q.; Xu, J.; Zhou, X.; Wang, T.; Xing, Q.; Liu, Y.; Wang, L.; He, L.; et al. Promoter hypomethylation of TIMP3 is associated with pre-eclampsia in a Chinese population. Mol. Hum. Reprod. 2013, 19, 153-159. [CrossRef]

181. Zhang, Y.; Fei, M.; Xue, G.; Zhou, Q.; Jia, Y.; Li, L.; Xin, H.; Sun, S. Elevated levels of hypoxia-inducible microRNA-210 in pre-eclampsia: New insights into molecular mechanisms for the disease. J. Cell. Mol. Med. 2012, 16, 249-259. [CrossRef] [PubMed] 
182. Wilson, S.L.; Leavey, K.; Cox, B.; Robinson, W.P. Mining DNA methylation alterations towards a classification of placental pathologies. Hum. Mol. Genet. 2018, 27, 135-146. [CrossRef] [PubMed]

183. Chelbi, S.T.; Wilson, M.L.; Veillard, A.C.; Ingles, S.A.; Zhang, J.; Mondon, F.; Gascoin-Lachambre, G.; Doridot, L.; Mignot, T.M.; Rebourcet, R.; et al. Genetic and epigenetic mechanisms collaborate to control SERPINA3 expression and its association with placental diseases. Hum. Mol. Genet. 2012, 21, 1968-1978. [CrossRef] [PubMed]

184. Hogg, K.; Blair, J.D.; McFadden, D.E.; von Dadelszen, P.; Robinson, W.P. Early onset pre-eclampsia is associated with altered DNA methylation of cortisol-signalling and steroidogenic genes in the placenta. PLOS ONE 2013, 8, e62969. [CrossRef] [PubMed]

185. Xirong, X.; Tao, X.; Wang, Y.; Zhu, L.; Ye, Y.; Liu, H.; Zhou, Q.; Li, X.; Xiong, Y. Hypomethylation of tissue factor pathway inhibitor 2 in human placenta of preeclampsia. Thrombosis Res. 2017, 152, 7-13.

186. Sundrani, D.P.; Reddy, U.S.; Joshi, A.A.; Mehendale, S.S.; Chavan-Gautam, P.M.; Hardikar, A.A. Differential placental methylation and expression of VEGF, FLT-1 and KDR genes in human term and preterm preeclampsia. Clin. Epigenet. 2013, 5. [CrossRef]

187. Ching, T.; Ha, J.; Song, M.A.; Tiirikainen, M.; Molnar, J.; Berry, M.J.; Towner, D.; Garmire, L.X. Genome-scale hypomethylation in the cord blood DNAs associated with early onset preeclampsia. Clin. Epigenet. 2015, 7, 21. [CrossRef]

188. Ye, W.; Shen, L.; Xiong, Y.; Zhou, Y.; Gu, H.; Yang, Z. Preeclampsia is Associated with Decreased Methylation of the GNA12 Promoter. Ann. Hum. Genet. 2016, 80, 7-10. [CrossRef]

189. Yuen, R.K.; Penaherrera, M.S.; von Dadelszen, P.; McFadden, D.E.; Robinson, W.P. DNA methylation profiling of human placentas reveals promoter hypomethylation of multiple genes in early-onset preeclampsia. Eur. J. Hum. Genet. 2010, 18, 1006-1012. [CrossRef]

190. Hogg, K.; Blair, J.D.; von Dadelszen, P.; Robinson, W.P. Hypomethylation of the LEP gene in placenta and elevated maternal leptin concentration in early onset pre-eclampsia. Mol. Cell. Endocrinol. 2013, 367, 64-73. [CrossRef]

191. Xiang, Y.; Cheng, Y.; Li, X.; Li, Q.; Xu, J.; Zhang, J.; Liu, Y.; Xing, Q.; Wang, L.; He, L.; et al. Up-regulated expression and aberrant DNA methylation of LEP and SH3PXD2A in pre-eclampsia. PLoS ONE 2013, 8, e59753. [CrossRef] [PubMed]

192. Hu, W.; Weng, X.; Dong, M.; Liu, Y.; Li, W.; Huang, H. Alteration in methylation level at $11 \beta$-hydroxysteroid dehydrogenase type 2 gene promoter in infants born to preeclamptic women. BMC Genet. 2014, 15, 96. [CrossRef] [PubMed]

193. Liu, Y.; Ma, Y. Promoter Methylation Status of WNT2 in Placenta from Patients with Preeclampsia. Med. Sci. Monit. Int. Med. J. Exp. Clin. Res. 2017, 23, 5294-5301. [CrossRef] [PubMed]

194. Ma, M.; Zhou, Q.-J.; Xiong, Y.; Li, B.; Li, X.-T. Preeclampsia is associated with hypermethylation of IGF-1 promoter mediated by DNMT1. Am. J. Transl. Res. 2018, 10, 16-39. [PubMed]

195. Rahat, B.; Thakur, S.; Bagga, R.; Kaur, J. Epigenetic regulation of STAT5A and its role as fetal DNA epigenetic marker during placental development and dysfunction. Placenta 2016, 44, 46-53. [CrossRef]

196. Choux, C.; Carmignac, V.; Bruno, C.; Sagot, P.; Vaiman, D.; Fauque, P. The placenta: Phenotypic and epigenetic modifications induced by Assisted Reproductive Technologies throughout pregnancy. Clin. Epigenet. 2015, 7, 87. [CrossRef] [PubMed]

197. Tang, Y.; Liu, H.; Li, H.; Peng, T.; Gu, W.; Li, X. Hypermethylation of the HLA-G promoter is associated with preeclampsia. Mol. Hum. Reprod. 2015, 21, 736-744. [CrossRef]

198. Konwar, C.; Del Gobbo, G.; Yuan, V.; Robinson, W.P. Considerations when processing and interpreting genomics data of the placenta. Placenta 2019. [CrossRef]

199. Tsang, J.C.H.; Vong, J.S.L.; Ji, L.; Poon, L.C.Y.; Jiang, P.; Lui, K.O.; Ni, Y.B.; To, K.F.; Cheng, Y.K.Y.; Chiu, R.W.K.; et al. Integrative single-cell and cell-free plasma RNA transcriptomics elucidates placental cellular dynamics. Proc. Natl. Acad. Sci. USA 2017, 114, E7786-E7795. [CrossRef]

200. Anacker, J.; Segerer, S.E.; Hagemann, C.; Feix, S.; Kapp, M.; Bausch, R.; Kammerer, U. Human decidua and invasive trophoblasts are rich sources of nearly all human matrix metalloproteinases. Mol. Hum. Reprod. 2011, 17, 637-652. [CrossRef]

201. Vettraino, I.M.; Roby, J.; Tolley, T.; Parks, W.C. Collagenase-I, stromelysin-I, and matrilysin are expressed within the placenta during multiple stages of human pregnancy. Placenta 1996, 17, 557-563. [CrossRef] 
202. Kocarslan, S.; Incebiyik, A.; Guldur, M.E.; Ekinci, T.; Ozardali, H.I. What is the role of matrix metalloproteinase-2 in placenta percreta? J. Obstet. Gynaecol. Res. 2015, 41, 1018-1022. [CrossRef] [PubMed]

203. Espino, Y.S.S.; Flores-Pliego, A.; Espejel-Nunez, A.; Medina-Bastidas, D.; Vadillo-Ortega, F.; Zaga-Clavellina, V.; Estrada-Gutierrez, G. New Insights into the Role of Matrix Metalloproteinases in Preeclampsia. Int. J. Mol. Sci. 2017, 18, 1448. [CrossRef] [PubMed]

204. Li, X.; Wu, C.; Shen, Y.; Wang, K.; Tang, L.; Zhou, M.; Yang, M.; Pan, T.; Liu, X.; Xu, W. Ten-eleven translocation 2 demethylates the MMP9 promoter, and its down-regulation in preeclampsia impairs trophoblast migration and invasion. J. Biol. Chem. 2018, 293, 10059-10070. [CrossRef] [PubMed]

205. White, W.M.; Brost, B.; Sun, Z.; Rose, C.; Craici, I.; Wagner, S.J.; Turner, S.T.; Garovic, V.D. Genome-wide methylation profiling demonstrates hypermethylation in maternal leukocyte DNA in preeclamptic compared to normotensive pregnancies. Hypertens. Pregnancy 2013, 32, 257-269. [CrossRef] [PubMed]

206. White, W.M.; Sun, Z.; Borowski, K.S.; Brost, B.C.; Davies, N.P.; Rose, C.H.; Garovic, V.D. Preeclampsia/Eclampsia candidate genes show altered methylation in maternal leukocytes of preeclamptic women at the time of delivery. Hypertens. Pregnancy 2016, 35, 394-404. [CrossRef] [PubMed]

207. Levine, R.J.; Maynard, S.E.; Qian, C.; Lim, K.H.; England, L.J.; Yu, K.F.; Schisterman, E.F.; Thadhani, R.; Sachs, B.P.; Epstein, F.H.; et al. Circulating angiogenic factors and the risk of preeclampsia. N. Engl. J. Med. 2004, 350, 672-683. [CrossRef] [PubMed]

208. Taglauer, E.S.; Wilkins-Haug, L.; Bianchi, D.W. Review: Cell-free fetal DNA in the maternal circulation as an indication of placental health and disease. Placenta 2014, 35 (Suppl.), S64-S68. [CrossRef]

209. Chim, S.S.; Tong, Y.K.; Chiu, R.W.; Lau, T.K.; Leung, T.N.; Chan, L.Y.; Oudejans, C.B.; Ding, C.; Lo, Y.M. Detection of the placental epigenetic signature of the maspin gene in maternal plasma. Proc. Natl. Acad. Sci. USA 2005, 102, 14753-14758. [CrossRef]

210. Qi, Y.H.; Teng, F.; Zhou, Q.; Liu, Y.X.; Wu, J.F.; Yu, S.S.; Zhang, X.; Ma, M.Y.; Zhou, N.; Chen, L.J. Unmethylated-maspin DNA in maternal plasma is associated with severe preeclampsia. Acta Obstet. Gynecol. Scand. 2015, 94, 983-988. [CrossRef]

211. Tsui, D.W.; Chan, K.C.; Chim, S.S.; Chan, L.W.; Leung, T.Y.; Lau, T.K.; Lo, Y.M.; Chiu, R.W. Quantitative aberrations of hypermethylated RASSF1A gene sequences in maternal plasma in pre-eclampsia. Prenat. Diagn. 2007, 27, 1212-1218. [CrossRef] [PubMed]

212. Salvianti, F.; Inversetti, A.; Smid, M.; Valsecchi, L.; Candiani, M.; Pazzagli, M.; Cremonesi, L.; Ferrari, M.; Pinzani, P.; Galbiati, S. Prospective evaluation of RASSF1A cell-free DNA as a biomarker of pre-eclampsia. Placenta 2015, 36, 996-1001. [CrossRef] [PubMed]

213. Mousa, A.A.; Archer, K.J.; Cappello, R.; Estrada-Gutierrez, G.; Isaacs, C.R.; Strauss, J.F., 3rd; Walsh, S.W. DNA methylation is altered in maternal blood vessels of women with preeclampsia. Reprod. Sci. 2012, 19, 1332-1342. [CrossRef] [PubMed]

214. Mousa, A.A.; Cappello, R.E.; Estrada-Gutierrez, G.; Shukla, J.; Romero, R.; Strauss, J.F., 3rd; Walsh, S.W. Preeclampsia is associated with alterations in DNA methylation of genes involved in collagen metabolism. Am. J. Pathol. 2012, 181, 1455-1463. [CrossRef] [PubMed]

215. Mousa, A.A.; Strauss, J.F., 3rd; Walsh, S.W. Reduced methylation of the thromboxane synthase gene is correlated with its increased vascular expression in preeclampsia. Hypertension 2012, 59, 1249-1255.

216. Nomura, Y.; Lambertini, L.; Rialdi, A.; Lee, M.; Mystal, E.Y.; Grabie, M.; Manaster, I.; Huynh, N.; Finik, J.; Davey, M.; et al. Global methylation in the placenta and umbilical cord blood from pregnancies with maternal gestational diabetes, preeclampsia, and obesity. Reprod. Sci. 2014, 21, 131-137. [CrossRef]

217. Chen, J.; Steegers-Theunissen, R.P.M.; van Meurs, J.B.; Felix, J.F.; Eggink, A.J.; Herzog, E.M.; Wijnands, K.P.J.; Stubbs, A.; Slieker, R.C.; van der Spek, P.J.; et al. Early- and late-onset preeclampsia and the tissue-specific epigenome of the placenta and newborn. Placenta 2017, 58, 122-132.

218. Novielli, C.; Mando, C.; Tabano, S.; Anelli, G.M.; Fontana, L.; Antonazzo, P.; Miozzo, M.; Cetin, I. Mitochondrial DNA content and methylation in fetal cord blood of pregnancies with placental insufficiency. Placenta 2017, 55, 63-70. [CrossRef]

219. Qiu, C.; Hevner, K.; Enquobahrie, D.A.; Williams, M.A. A case-control study of maternal blood mitochondrial DNA copy number and preeclampsia risk. Int. J. Mol. Epidemiol. Genet. 2012, 3, 237-244. 
220. Vishnyakova, P.A.; Volodina, M.A.; Tarasova, N.V.; Marey, M.V.; Tsvirkun, D.V.; Vavina, O.V.; Khodzhaeva, Z.S.; Kan, N.E.; Menon, R.; Vysokikh, M.Y.; et al. Mitochondrial role in adaptive response to stress conditions in preeclampsia. Sci. Rep. 2016, 6, 32410. [CrossRef]

221. Doridot, L.; Chatre, L.; Ducat, A.; Vilotte, J.L.; Lombes, A.; Mehats, C.; Barbaux, S.; Calicchio, R.; Ricchetti, M.; Vaiman, D. Nitroso-redox balance and mitochondrial homeostasis are regulated by STOX1, a pre-eclampsia-associated gene. Antioxid. Redox Signal. 2014, 21, 819-834. [CrossRef] [PubMed]

222. Brodowski, L.; Zindler, T.; von Hardenberg, S.; Schroder-Heurich, B.; von Kaisenberg, C.S.; Frieling, H.; Hubel, C.A.; Dork, T.; von Versen-Hoynck, F. Preeclampsia-Associated Alteration of DNA Methylation in Fetal Endothelial Progenitor Cells. Front. Cell Dev. Biol. 2019, 7, 32. [CrossRef] [PubMed]

223. Wang, X.; Chen, Y.; Du, L.; Li, X.; Li, X.; Chen, D. Evaluation of circulating placenta-related long noncoding RNAs as potential biomarkers for preeclampsia. Exp. Ther. Med. 2018, 15, 4309-4317. [CrossRef] [PubMed]

224. Yu, L.; Kuang, L.Y.; He, F.; Du, L.L.; Li, Q.L.; Sun, W.; Zhou, Y.M.; Li, X.M.; Li, X.Y.; Chen, D.J. The Role and Molecular Mechanism of Long Nocoding RNA-MEG3 in the Pathogenesis of Preeclampsia. Reprod. Sci. 2018, 25, 1619-1628. [CrossRef] [PubMed]

225. Jairajpuri, D.S.; Malalla, Z.H.; Mahmood, N.; Almawi, W.Y. Circulating microRNA expression as predictor of preeclampsia and its severity. Gene 2017, 627, 543-548. [CrossRef] [PubMed]

226. Lykoudi, A.; Kolialexi, A.; Lambrou, G.I.; Braoudaki, M.; Siristatidis, C.; Papaioanou, G.K.; Tzetis, M.; Mavrou, A.; Papantoniou, N. Dysregulated placental microRNAs in Early and Late onset Preeclampsia. Placenta 2018, 61, 24-32. [CrossRef] [PubMed]

227. Purwosunu, Y.; Sekizawa, A.; Okazaki, S.; Farina, A.; Wibowo, N.; Nakamura, M.; Rizzo, N.; Saito, H.; Okai, T. Prediction of preeclampsia by analysis of cell-free messenger RNA in maternal plasma. Am. J. Obstet. Gynecol. 2009, 200, 386.e1-386.e7. [CrossRef] [PubMed]

228. Tong, J.; Zhao, W.; Lv, H.; Li, W.P.; Chen, Z.J.; Zhang, C. Transcriptomic Profiling in Human Decidua of Severe Preeclampsia Detected by RNA Sequencing. J. Cell. Biochem. 2018, 119, 607-615. [CrossRef] [PubMed]

229. Zhang, Y.; Yang, L.; Chen, L.L. Life without A tail: New formats of long noncoding RNAs. Int. J. Biochem. Cell Biol. 2014, 54, 338-349. [CrossRef] [PubMed]

230. Hansen, T.B.; Jensen, T.I.; Clausen, B.H.; Bramsen, J.B.; Finsen, B.; Damgaard, C.K.; Kjems, J. Natural RNA circles function as efficient microRNA sponges. Nature 2013, 495, 384-388. [CrossRef] [PubMed]

231. Marchese, F.P.; Raimondi, I.; Huarte, M. The multidimensional mechanisms of long noncoding RNA function. Genome Biol. 2017, 18, 206. [CrossRef] [PubMed]

232. He, X.; He, Y.; Xi, B.; Zheng, J.; Zeng, X.; Cai, Q.; OuYang, Y.; Wang, C.; Zhou, X.; Huang, H.; et al. LncRNAs expression in preeclampsia placenta reveals the potential role of LncRNAs contributing to preeclampsia pathogenesis. PLoS ONE 2013, 8, e81437. [CrossRef] [PubMed]

233. Long, W.; Rui, C.; Song, X.; Dai, X.; Xue, X.; Lu, Y.; Shen, R.; Li, J.; Li, J.; Ding, H. Distinct expression profiles of IncRNAs between early-onset preeclampsia and preterm controls. Clin. Chim. Acta 2016, 463, 193-199. [CrossRef] [PubMed]

234. Hosseini, E.S.; Meryet-Figuiere, M.; Sabzalipoor, H.; Kashani, H.H.; Nikzad, H.; Asemi, Z. Dysregulated expression of long noncoding RNAs in gynecologic cancers. Mol. Cancer 2017, 16, 107. [CrossRef] [PubMed]

235. Amigorena, S. (C) 1998 Nature Publishing Group. Nature Medicine. 1998. Available online: http://www.nature. com/naturemedicine (accessed on 3 May 2019).

236. Mullen, C.A. Review: Analogies between trophoblastic and malignant cells. Am. J. Reprod. Immunol. 1998, 39, 41-49. [CrossRef] [PubMed]

237. Ferretti, C.; Bruni, L.; Dangles-Marie, V.; Pecking, A.P.; Bellet, D. Molecular circuits shared by placental and cancer cells, and their implications in the proliferative, invasive and migratory capacities of trophoblasts. Hum. Reprod. Update 2007, 13, 121-141. [CrossRef] [PubMed]

238. Genbacev, O.; Zhou, Y.; Ludlow, J.W.; Fisher, S.J. Regulation of human placental development by oxygen tension. Science 1997, 277, 1669-1672. [CrossRef] [PubMed]

239. Ji, P.; Diederichs, S.; Wang, W.; Böing, S.; Metzger, R.; Schneider, P.M.; Tidow, N.; Brandt, B.; Buerger, H.; Bulk, E.; et al. MALAT-1, a novel noncoding RNA, and thymosin $\beta 4$ predict metastasis and survival in early-stage non-small cell lung cancer. Oncogene 2003, 22, 8031-8041. [CrossRef] [PubMed]

240. Miyagawa, R.; Tano, K.; Mizuno, R.; Nakamura, Y.; Ijiri, K.; Rakwal, R.; Shibato, J.; Masuo, Y.; Mayeda, A.; Hirose, T.; et al. Identification of cis- and trans-acting factors involved in the localization of MALAT-1 noncoding RNA to nuclear speckles. RNA 2012, 18, 738-751. [CrossRef] 
241. Tseng, J.-J.; Hsieh, Y.-T.; Hsu, S.-L.; Chou, M.-M. Metastasis associated lung adenocarcinoma transcript 1 is up-regulated in placenta previa increta/percreta and strongly associated with trophoblast-like cell invasion in vitro. Mol. Hum. Reprod. 2009, 15, 725-731. [CrossRef]

242. Li, X.; Song, Y.; Liu, F.; Liu, D.; Miao, H.; Ren, J.; Xu, J.; Ding, L.; Hu, Y.; Wang, Z.; et al. Long Non-Coding RNA MALAT1 Promotes Proliferation, Angiogenesis, and Immunosuppressive Properties of Mesenchymal Stem Cells by Inducing VEGF and IDO. J. Cell. Biochem. 2017, 118, 2780-2791. [CrossRef] [PubMed]

243. Hass, R.; Kasper, C.; Böhm, S.; Jacobs, R. Different populations and sources of human mesenchymal stem cells (MSC): A comparison of adult and neonatal tissue-derived MSC. Cell Commun. Signal. 2011, 9, 12. [CrossRef] [PubMed]

244. Zhou, Y.; Zhang, X.; Klibanski, A. MEG3 noncoding RNA: A tumor suppressor. J. Mol. Endocinol. 2012, 48, 45-53. [CrossRef] [PubMed]

245. Davatzikos, C.; Rathore, S.; Bakas, S.; Pati, S.; Bergman, M.; Kalarot, R.; Sridharan, P.; Gastounioti, A.; Jahani, N.; Cohen, E.; et al. Cancer imaging phenomics toolkit: Quantitative imaging analytics for precision diagnostics and predictive modeling of clinical outcome. J. Med. Imaging 2018, 5, 011018. [CrossRef] [PubMed]

246. Yu, Y.C.; Jiang, Y.; Yang, M.M.; He, S.N.; Xi, X.; Xu, Y.T.; Hu, W.S.; Luo, Q. Hypermethylation of delta-like homolog 1/maternally expressed gene 3 loci in human umbilical veins: Insights into offspring vascular dysfunction born after preeclampsia. J. Hypertens. 2019, 37, 581-589. [CrossRef] [PubMed]

247. Yuan, J.H.; Yang, F.; Wang, F.; Ma, J.Z.; Guo, Y.J.; Tao, Q.F.; Liu, F.; Pan, W.; Wang, T.T.; Zhou, C.C.; et al. A Long Noncoding RNA Activated by TGF- $\beta$ promotes the invasion-metastasis cascade in hepatocellular carcinoma. Cancer Cell 2014, 25, 666-681. [CrossRef] [PubMed]

248. Liu, X.; Chen, H.; Kong, W.; Zhang, Y.; Cao, L.; Gao, L.; Zhou, R. Down-regulated long non-coding RNA-ATB in preeclampsia and its effect on suppressing migration, proliferation, and tube formation of trophoblast cells. Placenta 2017, 49, 80-87. [CrossRef] [PubMed]

249. Zheng, Q.; Zhang, D.; Yang, Y.U.; Cui, X.; Sun, J.; Liang, C.; Qin, H.; Yang, X.; Liu, S.; Yan, Q. MicroRNA-200c impairs uterine receptivity formation by targeting FUT4 and $\alpha 1$,3-fucosylation. Cell Death Differ. 2017, 24, 2161-2172. [CrossRef] [PubMed]

250. Renthal, N.E.; Chen, C.-C.; Williams, K.C.; Gerard, R.D.; Prange-Kiel, J.; Mendelson, C.R. miR-200 family and targets, ZEB1 and ZEB2, modulate uterine quiescence and contractility during pregnancy and labor. Proc. Natl. Acad. Sci. USA 2010, 107, 20828-20833. [CrossRef]

251. Paysan, L.; Piquet, L.; Saltel, F.; Moreau, V. Rnd3 in Cancer: A Review of the Evidence for Tumor Promoter or Suppressor. Mol. Cancer Res. 2016, 14, 1033-1044. [CrossRef]

252. Xu, Y.; Lian, Y.; Zhang, Y.; Huang, S.; Zuo, Q.; Yang, N.; Chen, Y.; Wu, D.; Sun, L. The long non-coding RNA PVT1 represses ANGPTL4 transcription through binding with EZH2 in trophoblast cell. J. Cell. Mol. Med. 2018, 22, 1272-1282. [CrossRef] [PubMed]

253. Feng, Y.; Wang, J.; He, Y.; Zhang, H.; Jiang, M.; Cao, D.; Wang, A. HOXD8/DIAPH2-AS1 epigenetically regulates PAX3 and impairs HTR-8/SVneo cell function under hypoxia. Biosci. Rep. 2019, 39, BSR20182022. [CrossRef] [PubMed]

254. Loupe, J.M.; Miller, P.J.; Bonner, B.P.; Maggi, E.C.; Vijayaraghavan, J.; Crabtree, J.S.; Taylor, C.M.; Zabaleta, J.; Hollenbach, A.D. Comparative transcriptomic analysis reveals the oncogenic fusion protein PAX3-FOXO1 globally alters mRNA and miRNA to enhance myoblast invasion. Oncogenesis 2016, 5, e246. [CrossRef] [PubMed]

255. Pineles, B.L.; Romero, R.; Montenegro, D.; Tarca, A.L.; Han, Y.M.; Kim, Y.M.; Draghici, S.; Espinoza, J.; Kusanovic, J.P.; Mittal, P.; et al. Distinct subsets of microRNAs are expressed differentially in the human placentas of patients with preeclampsia. Am. J. Obstet. Gynecol. 2007, 196, e261. [CrossRef] [PubMed]

256. Zhu, X.m.; Han, T.; Sargent, I.L.; Yin, G.w.; Yao, Y.q. Differential expression profile of microRNAs in human placentas from preeclamptic pregnancies vs normal pregnancies. Am. J. Obstet. Gynecol. 2009, 200 , e661. [CrossRef]

257. Biró, O.; Nagy, B.; Rigó, J. Identifying miRNA regulatory mechanisms in preeclampsia by systems biology approaches. Hypertens. Pregnancy 2017, 36, 90-99. [CrossRef]

258. Zhou, C.; Zou, Q.Y.; Li, H.; Wang, R.F.; Liu, A.X.; Magness, R.R.; Zheng, J. Preeclampsia Downregulates MicroRNAs in Fetal Endothelial Cells: Roles of miR-29a/c-3p in Endothelial Function. J. Clin. Endocrinol. Metab. 2017, 102, 3470-3479. [CrossRef] [PubMed] 
259. Yang, Z.; Wu, L.; Zhu, X.; Xu, J.; Jin, R.; Li, G.; Wu, F. MiR-29a modulates the angiogenic properties of human endothelial cells. Biochem. Biophys. Res. Commun. 2013, 434, 143-149. [CrossRef]

260. Davis, E.F.; Newton, L.; Lewandowski, A.J.; Lazdam, M.; Kelly, B.A.; Kyriakou, T.; Leeson, P. Pre-eclampsia and offspring cardiovascular health: Mechanistic insights from experimental studies. Clin. Sci. (Lond.) 2012, 123, 53-72. [CrossRef]

261. Butalia, S.; Audibert, F.; Cote, A.M.; Firoz, T.; Logan, A.G.; Magee, L.A.; Mundle, W.; Rey, E.; Rabi, D.M.; Daskalopoulou, S.S.; et al. Hypertension Canada's 2018 Guidelines for the Management of Hypertension in Pregnancy. Can. J. Cardiol. 2018, 34, 526-531. [CrossRef]

262. Yu, G.Z.; Reilly, S.; Lewandowski, A.J.; Aye, C.Y.L.; Simpson, L.J.; Newton, L.; Davis, E.F.; Zhu, S.J.; Fox, W.R.; Goel, A.; et al. Neonatal Micro-RNA Profile Determines Endothelial Function in Offspring of Hypertensive Pregnancies. Hypertension 2018, 72, 937-945. [CrossRef] [PubMed]

263. BAVELlONI, A.; Ramazzotti, G.; Poli, A.; Piazzi, M.; Focaccia, E.; Blalock, W.; Faenza, I. MiRNA-210: A Current Overview. Anticancer Res. 2017, 37, 6511-6521. [PubMed]

264. Kulshreshtha, R.; Ferracin, M.; Wojcik, S.E.; Garzon, R.; Alder, H.; Agosto-Perez, F.J.; Davuluri, R.; Liu, C.-G.; Croce, C.M.; Negrini, M.; et al. A MicroRNA Signature of Hypoxia. Mol. Cell. Biol. 2006, 27, 1859-1867. [CrossRef] [PubMed]

265. Chen, Z.; Li, Y.; Zhang, H.; Huang, P.; Luthra, R. Hypoxia-regulated microRNA-210 modulates mitochondrial function and decreases ISCU and COX10 expression. Oncogene 2010, 29, 4362-4368. [CrossRef] [PubMed]

266. Kelly, T.J.; Souza, A.L.; Clish, C.B.; Puigserver, P. A Hypoxia-Induced Positive Feedback Loop Promotes Hypoxia-Inducible Factor 1 Stability through miR-210 Suppression of Glycerol-3-Phosphate Dehydrogenase 1-Like. Mol. Cell. Biol. 2012, 32, 898. [CrossRef]

267. Fasanaro, P.; Di Stefano, V.; Melchionna, R.; Romani, S.; Pompilio, G.; Capogrossi, M.C.; Martelli, F. MicroRNA-210 Modulates Endothelial Cell Response to Hypoxia and Inhibits the Receptor Tyrosine Kinase Ligand Ephrin-A3. J. Biol. Chem. 2008, 283, 15878-15883. [CrossRef] [PubMed]

268. Cabello, C.M.; Bair, W.B.; Lamore, S.D.; Ley, S.; Alexandra, S.; Azimian, S.; Wondrak, G.T. The cinnamon-derived Michael acceptor cinnamic aldehyde impairs melanoma cell proliferation, invasiveness, and tumor growth. Free Radic. Biol. Med. 2009, 46, 220-231.

269. Lee, D.-C.; Romero, R.; Kim, J.-S.; Tarca, A.L.; Montenegro, D.; Pineles, B.L.; Kim, E.; Lee, J.; Kim, S.Y.; Draghici, S.; et al. miR-210 Targets Iron-Sulfur Cluster Scaffold Homologue in Human Trophoblast Cell Lines. Am. J. Pathol. 2011, 179, 590-602. [CrossRef]

270. Muralimanoharan, S.; Maloyan, A.; Mele, J.; Guo, C.; Myatt, L.G.; Myatt, L. MIR-210 modulates mitochondrial respiration in placenta with preeclampsia. Placenta 2012, 33, 816-823. [CrossRef]

271. Kopriva, S.E.; Chiasson, V.L.; Mitchell, B.M.; Chatterjee, P. TLR3-Induced Placental miR-210 Down-Regulates the STAT6/Interleukin-4 Pathway. PLoS ONE 2013, 8, e67760. [CrossRef]

272. Luo, R.; Shao, X.; Xu, P.; Liu, Y.; Wang, Y.; Zhao, Y.; Liu, M.; Ji, L.; Li, Y.X.; Chang, C.; et al. MicroRNA-210 contributes to preeclampsia by downregulating potassium channel modulatory factor 1. Hypertension 2014, 64, 839-845. [CrossRef] [PubMed]

273. Luo, R.; Wang, Y.; Xu, P.; Cao, G.; Zhao, Y.; Shao, X.; Li, Y.X.; Chang, C.; Peng, C.; Wang, Y.L. Hypoxia-inducible miR-210 contributes to preeclampsia via targeting thrombospondin type I domain containing 7A. Sci. Rep. 2016, 6, 19588. [CrossRef] [PubMed]

274. Chen, J.; Zhao, L.; Wang, D.; Xu, Y.; Gao, H.; Tan, W.; Wang, C. Contribution of regulatory T cells to immune tolerance and association of microRNA-210 and Foxp3 in preeclampsia. Mol. Med. Rep. 2019, 19, 1150-1158. [CrossRef]

275. Rudensky, A.Y. Regulatory T Cells and Foxp3. Immunol. Rev. 2011, 241, 260-268. [CrossRef] [PubMed]

276. Zhao, M.; Wang, L.T.; Liang, G.P.; Zhang, P.; Deng, X.J.; Tang, Q.; Zhai, H.Y.; Chang, C.C.; Su, Y.W.; Lu, Q.J. Up-regulation of microRNA-210 induces immune dysfunction via targeting FOXP3 in CD4(+) T cells of psoriasis vulgaris. Clin. Immunol. 2014, 150, 22-30. [CrossRef]

277. Zhang, Y.; Diao, Z.; Su, L.; Sun, H.; Li, R.; Cui, H.; Hu, Y. MicroRNA-155 contributes to preeclampsia by down-regulating CYR61. Am. J. Obstet. Gynecol. 2010, 202, e461-e466. [CrossRef] [PubMed]

278. Mo, F.-E.; Muntean, A.G.; Chen, C.-C.; Stolz, D.B.; Watkins, S.C.; Lau, L.F. CYR61 (CCN1) Is Essential for Placental Development and Vascular Integrity. Mol. Cell. Biol. 2002, 22, 8709-8720. [CrossRef] [PubMed]

279. Holbourn, K.; Ravi Acharya, K.; Perbal, B. The CCN family of proteins: Structure-function relationships. Trends Biochem. Sci. 2008, 33, 561-573. [CrossRef] 
280. Deloia, J.A.; Burlingame, J.M.; Krasnow, J.S. Differential Expression of G1 Cyclins During Human Placentogenesis. Placenta 1997, 18, 9-16. [CrossRef]

281. Baldin, V.; Marcote, M.J.; Lukas, J.; Draetta, G.; Pagano, M. Cyclin D1 is a nuclear protein required for cell cycle progression in G1. Genes Dev. 2007, 7, 812-821. [CrossRef] [PubMed]

282. Yung, H.-w.; Calabrese, S.; Hynx, D.; Hemmings, B.A.; Cetin, I.; Charnock-Jones, D.S.; Burton, G.J. Evidence of Placental Translation Inhibition and Endoplasmic Reticulum Stress in the Etiology of Human Intrauterine Growth Restriction. Am. J. Pathol. 2008, 173, 451-462. [CrossRef] [PubMed]

283. Yang, X.; Zhang, J.; Ding, Y. Association of microRNA-155, interleukin 17A, and proteinuria in preeclampsia. Medicine 2017, 96, e6509. [CrossRef] [PubMed]

284. Martin, D.B.; Nelson, P.S.; Knudsen, B.S.; Parkin, R.K.; Noteboom, J.; Kroh, E.M.; O’Briant, K.C.; Drescher, C.W.; Vessella, R.L.; Gentleman, R.; et al. Circulating microRNAs as stable blood-based markers for cancer detection. Proc. Natl. Acad. Sci. USA 2008, 105, 10513-10518.

285. Dai, Y.; Diao, Z.; Sun, H.; Li, R.; Qiu, Z.; Hu, Y. MicroRNA-155 is involved in the remodelling of human-trophoblast-derived HTR-8/SVneo cells induced by lipopolysaccharides. Hum. Reprod. 2011, 26, 1882-1891. [CrossRef] [PubMed]

286. Chambers, J.C.; Fusi, L.; Haskard, D.O.; Swiet, M.D.; Page, P. Association of Maternal Endothelial Dysfunction With Preeclampsia. JAMA J. Am. Med. Assoc. 2014, 28, 1607-1612.

287. Cheng, W.; Liu, T.; Jiang, F.; Liu, C.; Zhao, X.; Gao, Y.; Wang, H.; Liu, Z. microRNA-155 regulates angiotensin II type 1 receptor expression in umbilical vein endothelial cells from severely pre-eclamptic pregnant women. Int. J. Mol. Med. 2011, 27, 393-399. [PubMed]

288. Shan, H.Y.; Bai, X.J.; Chen, X.M. Angiotensin II induces endothelial cell senescence via the activation of mitogen-activated protein kinases. Cell Biochem. Funct. 2008, 26, 459-466. [CrossRef]

289. Seligman, S.P.; Buyon, J.P.; Clancy, R.M.; Young, B.K.; Abramson, S.B. The role of nitric oxide in the pathogenesis of preeclampsia. Am. J. Obstet. Gynecol. 1994, 171, 944-948. [CrossRef]

290. Sun, H.X.; Zeng, D.Y.; Li, R.T.; Pang, R.P.; Yang, H.; Hu, Y.L.; Zhang, Q.; Jiang, Y.; Huang, L.Y.; Tang, Y.B.; et al. Essential role of microRNA-155 in regulating endothelium-dependent vasorelaxation by targeting endothelial nitric oxide synthase. Hypertension 2012, 60, 1407-1414. [CrossRef]

291. Théry, C.; Zitvogel, L.; Amigorena, S. Exosomes: Composition, biogenesis and function. Nat. Rev. Immunol. 2002, 2, 569-579. [CrossRef]

292. Shen, L.; Li, Y.; Li, R.; Diao, Z.; Yany, M.; Wu, M.; Sun, H.; Yan, G.; Hu, Y. Placenta-associated serum exosomal miR-155 derived from patients with preeclampsia inhibits eNOS expression in human umbilical vein endothelial cells. Int. J. Mol. Med. 2018, 41, 1731-1739. [CrossRef] [PubMed]

293. Rensen, S.S.M.; Doevendans, P.A.F.M.; Van Eys, G.J.J.M. Regulation and characteristics of vascular smooth muscle cell phenotypic diversity. Neth. Heart J. 2007, 15, 100-108. [CrossRef] [PubMed]

294. Boerth, N.J.; Dey, N.B.; Cornwell, T.L.; Lincoln, T.M. Cyclic GMP-Dependent Protein Kinase Regulates Vascular Smooth Muscle Cell Phenotype. J. Vasc. Res. 1997, 34, 245-259. [CrossRef] [PubMed]

295. Lincoln, T.M.; Dey, N.B.; Boerth, N.J.; Cornwell, T.L.; Soff, G.A. Nitric oxide-Cyclic GMP pathway regulates vascular smooth muscle cell phenotypic modulation: Implications in vascular diseases. Acta Physiol. Scand. 1998, 164, 507-515. [CrossRef] [PubMed]

296. Choi, S.; Park, M.; Kim, J.; Park, W.; Kim, S.; Lee, D.K.; Hwang, J.Y.; Choe, J.; Won, M.H.; Ryoo, S.; et al. TNF- $\alpha$ elicits phenotypic and functional alterations of vascular smooth muscle cells by miR-155-5p-dependent down-regulation of cGMP-dependent kinase 1. J. Biol. Chem. 2018, 293, 14812-14822. [CrossRef] [PubMed]

297. Park, M.; Choi, S.; Kim, S.; Kim, J.; Lee, D.K.; Park, W.; Kim, T.; Jung, J.; Hwang, J.Y.; Won, M.H.; et al. NF-кB-responsive miR-155 induces functional impairment of vascular smooth muscle cells by downregulating soluble guanylyl cyclase. Exp. Mol. Med. 2019, 51, 17. [CrossRef]

298. Lo, Y.M.; Chiu, R.W. Prenatal diagnosis: Progress through plasma nucleic acids. Nat. Rev. Genet. 2007, 8, 71-77.

299. Chim, S.S.; Shing, T.K.; Hung, E.C.; Leung, T.Y.; Lau, T.K.; Chiu, R.W.; Lo, Y.M. Detection and characterization of placental microRNAs in maternal plasma. Clin. Chem. 2008, 54, 482-490. [CrossRef]

300. Gunel, T.; Zeybek, Y.G.; Akcakaya, P.; Kalelioglu, I.; Benian, A.; Ermis, H.; Aydinli, K. Serum microRNA expression in pregnancies with preeclampsia. Genet. Mol. Res. 2011, 10, 4034-4040. [CrossRef]

301. Li, Q.; Long, A.; Jiang, L.; Cai, L.; Xie, L.I.; Gu, J.; Chen, X.; Tan, L. Quantification of preeclampsia-related microRNAs in maternal serum. Biomed. Rep. 2015, 3, 792-796. [CrossRef] 
302. Munaut, C.; Tebache, L.; Blacher, S.; Noel, A.; Nisolle, M.; Chantraine, F. Dysregulated circulating miRNAs in preeclampsia. Biomed. Rep. 2016, 5, 686-692. [CrossRef] [PubMed]

303. Gan, L.; Liu, Z.; Wei, M.; Chen, Y.; Yang, X.; Chen, L.; Xiao, X. MIR-210 and miR-155 as potential diagnostic markers for pre-eclampsia pregnancies. Medicine 2017, 96, e7515. [CrossRef] [PubMed]

304. Hromadnikova, I.; Kotlabova, K.; Ivankova, K.; Krofta, L. First trimester screening of circulating C19MC microRNAs and the evaluation of their potential to predict the onset of preeclampsia and IUGR. PLoS ONE 2017, 12, e0171756. [CrossRef] [PubMed]

305. Winger, E.E.; Reed, J.L.; Ji, X.; Nicolaides, K. Peripheral blood cell microRNA quantification during the first trimester predicts preeclampsia: Proof of concept. PLoS ONE 2018, 13, e0190654. [CrossRef] [PubMed]

306. Moldovan, L.; Batte, K.E.; Trgovcich, J.; Wisler, J.; Marsh, C.B.; Piper, M. Methodological challenges in utilizing miRNAs as circulating biomarkers. J. Cell. Mol. Med. 2014, 18, 371-390. [CrossRef] [PubMed]

307. El-Khoury, V.; Pierson, S.; Kaoma, T.; Bernardin, F.; Berchem, G. Assessing cellular and circulating miRNA recovery: The impact of the RNA isolation method and the quantity of input material. Sci. Rep. 2016, 6, 19529. [CrossRef] [PubMed]

308. Xu, P.; Zhao, Y.; Liu, M.; Wang, Y.; Wang, H.; Li, Y.X.; Zhu, X.; Yao, Y.; Wang, H.; Qiao, J.; et al. Variations of microRNAs in human placentas and plasma from preeclamptic pregnancy. Hypertension 2014, 63, 1276-1284. [CrossRef]

309. Adel, S.; Mansour, A.; Louka, M.; Matboli, M.; Elmekkawi, S.F.; Swelam, N. Evaluation of MicroRNA-210 and Protein tyrosine phosphatase, non-receptor type 2 in Pre-eclampsia. Gene 2017, 596, 105-109. [CrossRef]

310. Manaster, I.; Goldman-Wohl, D.; Greenfield, C.; Nachmani, D.; Tsukerman, P.; Hamani, Y.; Yagel, S.; Mandelboim, O. MiRNA-Mediated Control of HLA-G Expression and Function. PLoS ONE 2012, 7, e33395. [CrossRef]

311. Su, M.-T.; Tsai, P.-Y.; Tsai, H.-L.; Chen, Y.-C.; Kuo, P.-L. miR-346 and miR-582-3p-regulated EG-VEGF expression and trophoblast invasion via matrix metalloproteinases 2 and 9. BioFactors 2017, 43, 210-219. [CrossRef]

312. Tan, Z.; Randall, G.; Fan, J.; Camoretti-Mercado, B.; Brockman-Schneider, R.; Pan, L.; Solway, J.; Gern, J.E.; Lemanske, R.F.; Nicolae, D.; et al. Allele-Specific Targeting of microRNAs to HLA-G and Risk of Asthma. Am. J. Hum. Genet. 2007, 81, 829-834. [CrossRef] [PubMed]

313. Zhang, Q.-H.; Sun, H.-M.; Zheng, R.-Z.; Li, Y.-C.; Zhang, Q.; Cheng, P.; Tang, Z.-H.; Huang, F. Meta-analysis of microRNA-183 family expression in human cancer studies comparing cancer tissues with noncancerous tissues. Gene 2013, 527, 26-32. [CrossRef] [PubMed]

314. Lasabova, Z.; Vazan, M.; Zibolenova, J.; Svecova, I. Overexpression of miR-21 and miR-122 in preeclamptic placentas. Neuro Endocrinol. Lett. 2015, 36, 695-699. [PubMed]

315. Gao, S.; Wang, Y.; Han, S.; Zhang, Q. Up-regulated microRNA-300 in maternal whole peripheral blood and placenta associated with pregnancy-induced hypertension and preeclampsia. Int. J. Clin. Exp. Pathol. 2017, $10,4232-4242$.

316. Turco, M.Y.; Gardner, L.; Kay, R.G.; Hamilton, R.S.; Prater, M.; Hollinshead, M.S.; McWhinnie, A.; Esposito, L.; Fernando, R.; Skelton, H.; et al. Trophoblast organoids as a model for maternal-fetal interactions during human placentation. Nature 2018, 564, 263-267. [CrossRef]

317. Coutifaris, C.; Kao, L.C.; Sehdev, H.M.; Chin, U.; Babalola, G.O.; Blaschuk, O.W.; Strauss, J.F. E-cadherin expression during the differentiation of human trophoblasts. Development (Camb. Engl.) 1991, 113, 767-777.

318. Chakraborty, D.; Cui, W.; Rosario, G.X.; Scott, R.L.; Dhakal, P.; Renaud, S.J.; Tachibana, M.; Rumi, M.A.; Mason, C.W.; Krieg, A.J.; et al. HIF-KDM3A-MMP12 regulatory circuit ensures trophoblast plasticity and placental adaptations to hypoxia. Proc. Natl. Acad. Sci. USA 2016, 113, E7212-E7221. [CrossRef]

319. Alahari, S.; Post, M.; Rolfo, A.; Weksberg, R.; Caniggia, I. Compromised JMJD6 Histone Demethylase Activity Affects VHL Gene Repression in Preeclampsia. J. Clin. Endocrinol. Metab. 2018, 103, 1545-1557. [CrossRef]

320. Xie, D.; Zhu, J.; Liu, Q.; Li, J.; Song, M.; Wang, K.; Zhou, Q.; Jia, Y.; Li, T. Dysregulation of HDAC9 Represses Trophoblast Cell Migration and Invasion Through TIMP3 Activation in Preeclampsia. Am. J. Hypertens. 2019, 32, 515-523. [CrossRef]

321. Zadora, J.; Singh, M.; Herse, F.; Przybyl, L.; Haase, N.; Golic, M.; Yung, H.W.; Huppertz, B.; Cartwright, J.E.; Whitley, G.; et al. Disturbed Placental Imprinting in Preeclampsia Leads to Altered Expression of DLX5, a Human-Specific Early Trophoblast Marker. Circulation 2017, 136, 1824-1839. [CrossRef] 
322. Van Dijk, M.; Mulders, J.; Poutsma, A.; Konst, A.A.; Lachmeijer, A.M.; Dekker, G.A.; Blankenstein, M.A.; Oudejans, C.B. Maternal segregation of the Dutch preeclampsia locus at $10 q 22$ with a new member of the winged helix gene family. Nat. Genet. 2005, 37, 514-519. [CrossRef] [PubMed]

323. Van Dijk, M.; van Bezu, J.; van Abel, D.; Dunk, C.; Blankenstein, M.A.; Oudejans, C.B.; Lye, S.J. The STOX1 genotype associated with pre-eclampsia leads to a reduction of trophoblast invasion by alpha-T-catenin upregulation. Hum. Mol. Genet. 2010, 19, 2658-2667. [CrossRef] [PubMed]

324. Rigourd, V.; Chauvet, C.; Chelbi, S.T.; Rebourcet, R.; Mondon, F.; Letourneur, F.; Mignot, T.M.; Barbaux, S.; Vaiman, D. STOX1 overexpression in choriocarcinoma cells mimics transcriptional alterations observed in preeclamptic placentas. PLoS ONE 2008, 3, e3905. [CrossRef] [PubMed]

325. Graves, J.A. Genomic imprinting, development and disease-is pre-eclampsia caused by a maternally imprinted gene? Reprod. Fertil. Dev. 1998, 10, 23-29. [CrossRef] [PubMed]

(C) 2019 by the authors. Licensee MDPI, Basel, Switzerland. This article is an open access article distributed under the terms and conditions of the Creative Commons Attribution (CC BY) license (http://creativecommons.org/licenses/by/4.0/). 